\title{
ESTUDO DAS INFECÇÕES POR HEMOPLASMAS EM CÃES E GATOS DOMÉSTICOS
}

LARISSA CAMPOS AQUINO

TESE DE DOUTORADO EM SAÚDE ANIMAL

\author{
BRASÍLIA-DF \\ DEZEMBRO/2015
}




\title{
ESTUDO DAS INFECÇÕES POR HEMOPLASMAS EM CÃES E GATOS DOMÉSTICOS
}

LARISSA CAMPOS AQUINO

TESE DE DOUTORADO EM SAÚDE ANIMAL

\author{
BRASÍLIA-DF \\ DEZEMBRO/2015
}




\section{ESTUDO DAS INFECÇÕES POR HEMOPLASMAS EM CÃES E GATOS DOMÉSTICOS}

LARISSA CAMPOS AQUINO

ORIENTADORA: PROFa. DRa.GIANE REGINA PALUDO

TESE DE DOUTORADO EM SAÚDE ANIMAL

PUBLICAÇÃO: 001/2015

BRASÍLIA-DF

DEZEMBRO/2015 


\section{ESTUDO DAS INFECÇÕES POR HEMOPLASMAS EM CÃES E GATOS DOMÉSTICOS}

LARISSA CAMPOS AQUINO

TESE DE DOUTORADO SUBMETIDA AO PROGRAMA DE PÓS-GRADUAÇÃO EM SAÚDE ANIMAL COMO PARTE DOS REQUISITOS NECESSÁRIOS À OBTENÇÃO DO GRAU DE DOUTOR EM SAÚDE ANIMAL.

APROVADO POR:

Gnom A Baludo.

GIANE REGINA PALUDO (ORIENTADOR)

Doutorado em Patologia Molecular

Professor Adjunto UnB - FAV

SIMONE PERECMANIS (EXAMINADOR INTERNO)

Doutorado em Patologia Molecular

Professor Adjunto UnB - FAV

JAIR COSTA JR (EXAMINADOR EXTERNO)

Doutorado em Medicina Veterinária

Professor Adjunto UnB - FAV

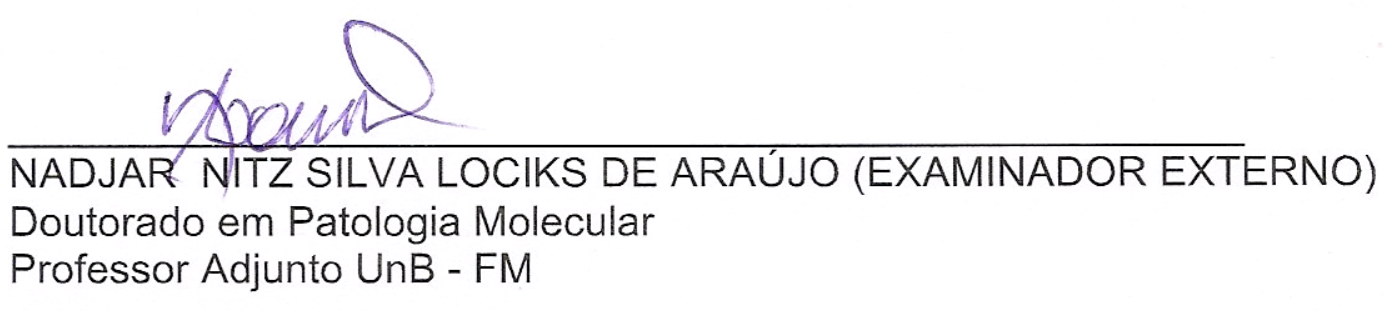


Salvina dos santer coste Poagani

SABRINA DOS SANTOS COSTAPOGGIANI (EXAMINADOR EXTERNO)

Doutorado em Medicina Veterinária

Docente da UPIS

Brasilia-DF, 01 de Dezembro de 2015 


\section{REFERÊNCIA BIBLIOGRÁFICA E CATALOGAÇÃO}

AQUINO, L. C. Estudo das infecções por hemoplasmas em cães e gatos domésticos. Brasília: Faculdade de Agronomia e Medicina Veterinária, Universidade de Brasília, 2015, 92p. Tese de Doutorado.

Documento formal autorizando reprodução desta tese de doutorado, empréstimo ou comercialização exclusivamente para fins acadêmicos, foi passado pelo autor à Universidade de Brasília e acha-se arquivado na secretaria do programa. O autor reserva para si os outros direitos autorais de publicação. Nenhuma parte dessa tese pode ser reproduzida sem a autorização por escrito do autor. Citações são estimuladas, desde que citada a fonte.

FICHA CATALOGRÁFICA

Aquino, Larissa Campos

Estudo das infecções por hemoplasmas em cães e gatos domésticos/ Larissa Campos Aquino orientação de Giane Regina Paludo - Brasília, 2015. 92p. : il. Tese de Doutorado (D) - Universidade de Brasília / Faculdade de Agronomia e Medicina Veterinária, 2015

1. Hemoplasmas. 2. Felinos. 3. Hematologia. 4. Caninos. 5. Filogenia. 6. Hematologia I. AQUINO L. C. II. Título. 


\section{AGRADECIMENTOS}

Meu maior obrigada a minha mãe, Lourdes, por ser não só mãe, mas também pai, amiga, torcedora, guerreira e porto seguro. Ela é meu principal exemplo de ser humano. Dedico e ofereço a ela todas minhas conquistas. Muito obrigada por ser minha maior incentivadora e, principalmente, por acreditar na minha capacidade, até quando eu mesma não acredito.

Obrigada ao meu marido Darien por ser grande exemplo de otimismo, bondade e força, por me apoiar incondicionalmente e acreditar em mim. Obrigada pela vida que decidimos trilhar juntos e por tanto amor!

Obrigada vó Diva, minha segunda mãe, pelos cuidados e orações. Elas têm funcionado!

Obrigada aos meus irmãos, Eduardo, Marlos e Rovena, por toda oportunidade de aprendizado, por serem exemplos tão diferentes e se preocuparem comigo. Aos meus sobrinhos Guilherme e Felipe, que em tão pouco tempo já conquistaram tanto amor em nossos corações e pelas fofuras diárias!

Obrigada pela amizade verdadeira, Patrícia, Bruna e Daniela! E por me ensinarem em todos os momentos de convívio e pelo apoio incondicional a qualquer hora!

Obrigada Tatiana por todo apoio moral, técnico e intelectual de sua mente brilhante! Obrigada pela paciência e pelas inúmeras ajudas!

Obrigada aos colegas de laboratório por toda ajuda e apoio.

Meus agradecimentos a minha orientadora, Giane, pela oportunidade oferecida e pela orientação ao longo de tantos anos. Obrigada por ter acreditado no que eu podia oferecer e pela liberdade que tive ao longo dessa pesquisa.

Obrigada à CAPES pelo apoio financeiro para que eu pudesse me dedicar exclusivamente a pesquisa e para que eu realizasse o doutorado 
sanduíche na Universidade de Bristol. Obrigada à FAPDF por financiar a apresentação desse projeto em congressos internacionais.

Por fim, sou muito grata ao que o doutorado me proporcionou: conhecimento, descobertas, oportunidades e novos horizontes! Espero que esse conteúdo possa contribuir de alguma forma àqueles que se interessam pelas hemoplasmoses. 


\section{ESTUDO DAS INFECÇÕES POR HEMOPLASMAS EM CÃES E GATOS DOMÉSTICOS}

\section{RESUMO}

Hemoplasmas são micoplasmas hemotrópicos que não possuem parede celular e crescem na superfície de eritrócitos podendo causar anemia infecciosa em diferentes espécies de mamíferos. Gatos são infectados por três espécies principais: Mycoplasma haemofelis (Mhf), 'Candidatus Mycoplasma haemominutum' (CMhm) e 'Candidatus Mycoplasma turicensis' (CMt) e em cães as espécies Mycoplasma haemocanis (Mhc) e 'Candidatus Mycoplasma haematoparvum' (CMhp) são as mais prevalentes. O presente estudo teve como objetivos determinar a ocorrência e a filogenia das espécies de hemoplasmas em gatos da capital do Brasil e cidades satélites e de cães da Nigéria, África, e verificar se há correlação com alterações hematológicas. Amostras de sangue foram coletadas de 451 gatos de diferentes origens de Brasília, DF e de 246 cães de Jos, Plateau State, Nigeria e submetidas a avaliação eritrocitária e extração de DNA para PCRs e sequenciamento. No estudo em gatos, hemoplasmas foram encontrados em $13.8 \%$ dos animais. CMhm foi a espécie mais prevalente $(13.8 \%$ dos gatos), seguida pelo Mhf (11.1\%) e CMt $(4.4 \%)$. Mais de $80 \%$ dos gatos infectados por hemoplasmas estavam infectados por duas ou mais espécies: 7.1\% estavam co-infectados com Mhf/CMhm, 0,4\% com CMhm/CMt e 3,9\% com $\mathrm{Mhf} / \mathrm{CMhm} / \mathrm{CMt}$. O gênero masculino estava significativamente associado com infecção por hemoplasmas. Nenhuma associação entre o resultado da qPCR para hemoplasmas e parâmetros hematológicos foi encontrada, porém o número relativo de cópias de $\mathrm{CMhm}$ apresentou correlação com o número de eritrócitos e hematócrito. As sequencias do gene $16 \mathrm{~S}$ rRNA (>1Kb) das espécies de hemoplasmas provenientes de gatos com co-infecções foram obtidos usando oligonucleotídeos espécie específicos, o que permitiu a obtenção de sequencias do gene 16S rRNA apesar do alto nível de co-infecções, que impossibilita o uso de oligonucleotídeos universais para o gene $16 S$ rRNA. Dentro de cada espécie as sequencias de Mhf, CMhm e CMt apresentaram identidade de $>99.8 \%$, $>98.5 \%$ e $>98.8 \%$,respectivamente. As sequencias de Mhf, CMhm e CMt 
apresentaram $>99.2 \%,>98.4 \%$ e $>97.8 \%$ de identidade, respectivamente, com sequencias do GenBank. A análise filogenética demonstrou todas as sequencias do Mhf em um único grupo, enquanto as sequencias de CMhm e CMt se agruparam em 3 subgrupos distintos. Estes achados filogenéticos sugerem a existência de diferentes cepas de CMhm e CMt. No estudo em cães, a qPCR espécie específica detectou infecção por Mhc em 18 dos 245 cães $(7,3 \%)$ e CMhp em apenas um cão $(0,4 \%)$. A qPCR de gênero de hemoplasmas foi positiva em 44 dos 245 (17,9\%) dos cães. Vinte e cinco cães tiveram resultados discordantes nas qPCRs, nos quais foram positivos na qPCR de gênero de hemoplasmas, mas negativos na GPCR espécie específica. A avaliação desses cães discordantes por meio do sequenciamento do gene 16S rRNA gerou resultados limitados, mas em 5 cães confirmou-se a infecção por espécies diferentes de hemoplasmas: 2 Anaplasma phagocytophilum, 1 Anaplasma ovis, 1 Serratia marcescens e 1 Aerococcus spp. O sequenciamento do gene 16S rRNA dos Mhc mostrou $>99,8 \%$ de identidade entre elas e $>99,6 \%$ de identidade com sequencias disponíveis no GenBank e permaneceram no mesmo grupo de outras sequencias de Mhc e Mycoplasma haemofelis, indicando baixa variabilidade genética do gene $16 \mathrm{~S}$ rRNA entre Mhc de diferentes origens.

Palavras-chave: hemoplasmas, cães, gatos, prevalência, filogenia 


\section{STUDY OF THE HAEMOPLASMA INFECTIONS IN DOMESTIC DOGS AND CATS}

\section{ABSTRACT}

Haemoplasmas are wall less haemotropic mycoplasmas that attach and grown in the surface of erythrocytes and cause anaemia in different mammals species. Cats are infected with three main species: Mycoplasma haemofelis (Mhf), 'Candidatus Mycoplasma haemominutum' (CMhm) and 'Candidatus Mycoplasma turicensis' (CMt), while in dogs the species Mycoplasma haemocanis (Mhc) and 'Candidatus Mycoplasma haematoparvum' (CMhp) are the most prevalent. The aims of the present study were to determine the occurrence and the phylogeny of haemoplasma species from cats in Brasilia and surrounding cities and from dogs in Nigeria, Africa; and assess weather any correlation existed between haemoplasma infection and haematological abnormalities. Blood samples were collected from 451 cats in different origins of Brasília, DF and from 246 dogs from Jos, Plateau State, Nigeria; submitted to erythrocyte evaluation and DNA extraction for PCR analysis and sequencing. In the cats study, haemoplasmas were found in $13.8 \%$ of 432 cats. CMhm was the most prevalent species (in $13.8 \%$ of cats), followed by Mhf $(11.1 \%)$ and CMt $(4.4 \%)$. Over $80 \%$ of haemoplasma-infected cats harboured two or more feline haemoplasma species: $7.1 \%$ of cats were coinfected with $\mathrm{Mhf} / \mathrm{CMhm}, \quad 0.4 \%$ with $\mathrm{CMhm} / \mathrm{CMt}$ and $3.9 \%$ with $\mathrm{Mhf} / \mathrm{CMhm} / \mathrm{CMt}$. Male gender was significantly associated with haemoplasma infections. No association was found between QPCR haemoplasma status and haematological variables, however $\mathrm{CMhm}$ relative copy numbers were correlated with red blood cell (RBC) numbers and packed cell volume (PCV). Haemoplasma 16S rRNA gene sequences $(>1 \mathrm{~Kb})$ were derived from coinfected cats using novel haemoplasma species-specific oligonucleotides. This allowed 16S rRNA gene sequences to be obtained despite the high level of co-infection, which precluded the use of universal 16S rRNA gene oligonucleotides. Within each species, the Mhf, $\mathrm{CMhm}$ and $\mathrm{CMt}$ sequences showed $>99.8 \%,>98.5 \%$ and $>98.8 \%$ identity, respectively. The Mhf, CMhm and CMt sequences showed $>99.2 \%,>98.4 \%$ and $>97.8 \%$ identity, respectively, with GenBank sequences. Phylogenetic analysis showed all Mhf 
sequences to reside in a single clade, whereas the $\mathrm{CMhm}$ and $\mathrm{CMt}$ sequences each grouped into three distinct subclades. These phylogeny findings suggest the existence of different $\mathrm{CMhm}$ and CMt strains. In the dogs study, species-specific qPCR assays found Mhc infection in 18 of 245 dogs (7.3\%), and CMhp infection in only one dog (0.4\%). The generic haemoplasma qPCR assays were positive in 44 of 245 (17.9\%) dogs. Twentyfive dogs had discordant QPCR results in that they were generic haemoplasma qPCR positive but species-specific qPCR negative. Further evaluation of these dogs by $16 \mathrm{~S}$ rDNA sequencing gave limited results but 5 were confirmed to be infected with non-haemoplasma species: The 16S rRNA gene sequences from Mhc species showed $>99.8 \%$ identity with each other and $>99.6 \%$ identity with GenBank sequences, and resided in a single clade with other global Mhc and Mycoplasma haemofelis sequences, indicating low $16 S$ rRNA genetic variability amongst this canine haemoplasma species.

Keywords: haemoplasmas, dogs, cats, prevalence, phylogeny 


\section{LISTA DE FIGURAS}

\section{ARTIGO 1}

Página

Figura 1.1. Número relativo de cópias de DNA de hemoplasma/ $\mu$ l de sangue para cada espécie de hemoplasma das amostras com resultados positivos na qPCR. Boxplots representando os quartis de 25th, 50th (mediana) e 75 th com whiskers representando os maiores e menores valores. Mhf $=$ gatos positivos na qPCR para Mycoplasma haemofelis, CMhm = gatos positivos na qPCR para "Candidatus Mycoplasma haemominutum", $\mathrm{CMt}=$ gatos positivos na qPCR para "Candidatus Mycoplasma turicensis".

Figura 1.2. Diagrama representando o número de gatos positivos nas qPCRs espécie específicas incluindo a quantidade de gatos com infecções por duas e três espécies de hemoplasmas. Mhf $=$ gatos positivos na qPCR para Mycoplasma haemofelis, $\mathrm{CMhm}=$ gatos positivos na $\mathrm{qPCR}$ para "Candidatus Mycoplasma haemominutum", CMt = gatos positivos na qPCR para "Candidatus Mycoplasma turicensis"......

Figura 1.3. Análise filogenética das sequencias do gene $16 \mathrm{~S}$ rRNA das espécies Mhf, CMhm e CMt de gatos de Brasília e cidades satélites. O método de Neighbor-Joining foi usado para construir a árvore filogenética, cujos valores de bootstrap nos nodos (apenas valores $\geq 700$ são mostrados). As distâncias evolucionárias estão na escala. Clostridium spp. foi usado como grupo externo. Os números de acesso no GenBank estão indicados na figura. As sequencias de Mhf (B6, B7, C6, D4, E7, F2, F3, F5, G4, H2), CMhm (A8, B4, B5, B8, D1, D2, D4, D5, E3, H4) e CMt (B1, B2, D4, E7, F3, F4, 
F5, G1, G4, G5, H4) foram geradas no presente estudo. Mhf= Mycoplasma haemofelis, CMhm= "Candidatus Mycoplasma haemominutum", CMt= "Candidatus Mycoplasma turicensis".

\section{ARTIGO 2}

Figura 2.1. Relações filogenéticas das sequencias do gene 16S rRNA de hemoplasmas previamente publicadas e de Mhc de cães da Nigéria. Valores de porcentagem de bootstrap estão nos nodos da árvore flogenética (apenas valores $>700$ estão apresentados). As distâncias evolucionárias estão representadas na escala. Clostridium spp. foi usado como grupo externo. Os números de acesso ao GenBank estão indicados na figura. Sequencias de Mhc dos animais F2, G7, H7 e E8 foram geradas no presente estudo. Número de acesso ao nucleotídeo no Genbank (KP715857, KP715858, KP715859 and KP715860). Mhc = Mycoplasma haemocanis, $\mathrm{CMhp}=$ "Candidatus Mycoplasma haematoparvum", Mhf = Mycoplasma haemofelis, CMhm = "Candidatus Mycoplasma haemominutum" 


\section{LISTA DE TABELAS}

ARTIGO 1

Página

Tabela 1.1. Sequencias dos oligonucleotídeos desenhados para a PCR convencional espécie específica para o sequenciamento do gene 16S rRNA de hemoplasmas de gatos infectados por múltiplas espécies.

Tabela 1.2. Número e porcentagem de gatos com resultados positivos na PCR para espécies de hemoplasmas no método convencional e em tempo real (quantitativo).

Tabela 1.3. Estatística descritiva (mediana e variação) e resultados do teste Kruskal-Wallis (valor p) para as variáveis hematológicas nos gatos agrupados de acordo com o resultado da qPCR espécie específica.

\section{ARTIGO 2}

Tabela 2.1. Características dos cães amostrados e resultados da PCR

Tabela 2.2. Percentual de amostras de sague de cães positivas para espécies de hemoplasmas (Mhc e CMhp) por PCR 


\section{SUMÁRIO}

1.1 Artigo 1: Prevalência e análise filogenética dos hemoplasmas

de gatos infectados por múltiplas espécies.................................... 1

1.2 Abstract e Resumo............................................................. 2

1.3 Introdução ........................................................................... 4

1.4 Material e métodos............................................................ 6

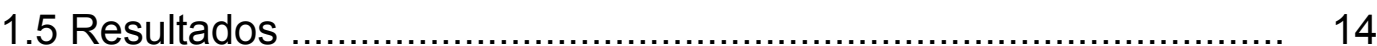

1.6 Discussão ......................................................................... 18

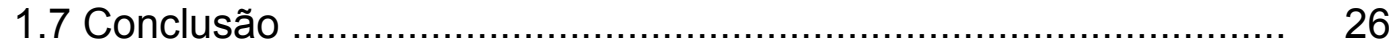

Referências Bibliográficas...................................................... 27

\section{CAPÍTULO II}

2.1 Artigo 1: Análise dos fatores de risco e ocorrência das infecções por hemoplasmas em cães ..................................................... 38

2.2 Abstract e Resumo................................................................ 39

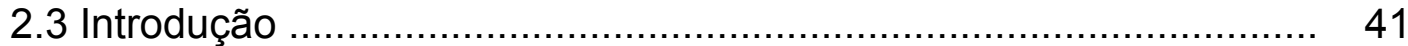

2.4 Material e métodos .............................................................. 43

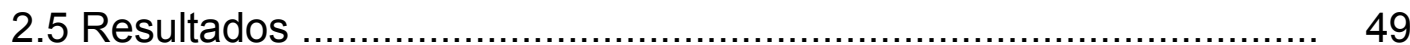

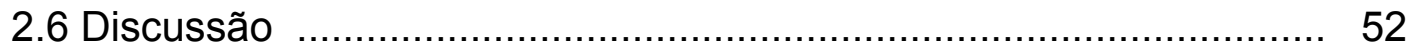

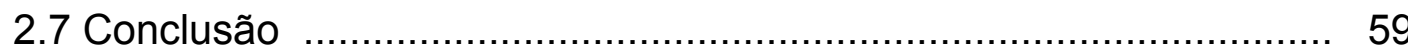

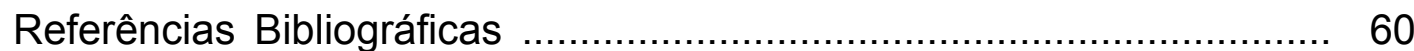




\section{CAPÍTULO 1}

\section{ARTIGO 1. PREVALÊNCIA E ANÁLISE FILOGENÉTICA DOS HEMOPLASMAS DE GATOS INFECTADOS POR MÚLTIPLAS ESPÉCIES}

Larissa Campos Aquino ${ }^{a^{*}}$, Chelsea A. Hicks ${ }^{b}$, Marcela C. Scalon ${ }^{a}$, Maíra G. da M. Lima ${ }^{a}$, Marcelle dos S. Lemos ${ }^{a}$, Giane Regina Paludo ${ }^{a}$, Chris R. Helps $^{\mathrm{b}, \mathrm{c}}$, Séverine Tasker ${ }^{\mathrm{b}, \mathrm{c}}$

aLaboratorio de Patologia Clinica Veterinária, Faculdade de Agronomia e Medicina Veterinária, Universidade de Brasília, Campus Universitário Darcy Ribeiro, Brasília, Brasil, 709010-900

bSchool of Veterinary Sciences, University of Bristol, Langford House, Langford, Bristol BS40 5DU, UK

'Molecular Diagnostic Unit, Langford Veterinary Services, Langford, Bristol, BS40 5DU.

\section{Autor para correspondência*}

E-mail: larissaquino@gmail.com

PUBLICADO: Aquino, L.C., Hicks, C.A.E., Scalon, M.C., Lima, M.G.M., Lemos, M.S., Paludo, G.R., Helps, C.R., Tasker, S. 2014. Prevalence and phylogenetic analysis of haemoplasmas from cats infected with multiple species. Journal of Microbiological Methods 107, 189-196. (ANEXO A). 


\subsection{Abstract}

Mycoplasma haemofelis (Mhf), 'Candidatus Mycoplasma haemominutum' (CMhm) and 'Candidatus Mycoplasma turicensis' (CMt) are agents of feline haemoplasmosis and can induce anaemia in cats. This study aimed to determine the prevalence and phylogeny of haemoplasma species in cats from Brazil's capital and surrounding areas, and whether correlation with haematological abnormalities existed. Feline haemoplasmas were found in $13.8 \%$ of 432 cats. CMhm was the most prevalent species (in $13.8 \%$ of cats), followed by Mhf (11.1\%) and CMt (4.4\%). Over $80 \%$ of haemoplasma-infected cats harboured two or more feline haemoplasma species: $7.1 \%$ of cats were co-infected with $\mathrm{Mhf} / \mathrm{CMhm}, 0.4 \%$ with $\mathrm{CMhm} / \mathrm{CMt}$ and $3.9 \%$ with $\mathrm{Mhf} / \mathrm{CMhm} / \mathrm{CMt}$. Male gender was significantly associated with haemoplasma infections. No association was found between qPCR haemoplasma status and haematological variables, however $\mathrm{CMhm}$ relative copy numbers were correlated with red blood cell (RBC) numbers and packed cell volume (PCV). Haemoplasma 16S rRNA gene sequences $(>1 \mathrm{~Kb})$ were derived from coinfected cats using novel haemoplasma species-specific oligonucleotides. This allowed 16S rRNA gene sequences to be obtained despite the high level of co-infection, which precluded the use of universal 16S rRNA gene oligonucleotides. Within each species, the Mhf, CMhm and CMt sequences showed $>99.8 \%,>98.5 \%$ and $>98.8 \%$ identity, respectively. The Mhf, CMhm and CMt sequences showed $>99.2 \%,>98.4 \%$ and $>97.8 \%$ identity, respectively, with GenBank sequences. Phylogenetic analysis showed all Mhf sequences to reside in a single clade, whereas the $\mathrm{CMhm}$ and $\mathrm{CMt}$ sequences each grouped into three distinct subclades. These phylogeny findings suggest the existence of different CMhm and CMt strains.

Keywords: haemoplasma, Brazil, cats, prevalence, co-infections 


\section{Resumo}

Mycoplasma haemofelis (Mhf), 'Candidatus Mycoplasma haemominutum' (CMhm) e 'Candidatus Mycoplasma turicensis' (CMt) são os agentes causadores da hemoplasmose felina e podem induzir anemia em gatos. O presente estudo teve como objetivos determinar a prevalência e a filogenia das espécies de hemoplasmas em gatos da capital do Brasil e cidades satélites, e verificar se há correlação com alterações hematológicas. Hemoplasmas foram encontrados em $13.8 \%$ de 432 gatos. CMhm foi a espécie mais prevalente (13.8\% dos gatos), seguida pelo Mhf (11.1\%) e CMt (4.4\%). Mais de $80 \%$ dos gatos infectados por hemoplasmas estavam infectados por duas ou mais espécies: $7.1 \%$ estavam co-infectados com Mhf/CMhm, 0,4\% com CMhm/CMt e 3,9\% com Mhf/CMhm/CMt. O gênero masculino estava significativamente associado com infecção por hemoplasmas. Nenhuma associação entre o resultado da qPCR para hemoplasmas e parâmetros hematológicos foi encontrada, porém o número relativo de cópias de $\mathrm{CMhm}$ apresentou correlação com o número de eritrócitos e hematócrito. As sequencias do gene 16S rRNA (>1Kb) das espécies de hemoplasmas provenientes de gatos com co-infecções foram obtidos usando oligonucleotídeos espécie específicos, o que permitiu a obtenção de sequencias do gene 16S rRNA apesar do alto nível de coinfecções, que impossibilita o uso de oligonucleotídeos universais para o gene $16 \mathrm{~S}$ rRNA. Dentro de cada espécie as sequencias de Mhf, CMhm e CMt apresentaram identidade de $>99.8 \%,>98.5 \%$ e $>98.8 \%$, respectivamente. As sequencias de Mhf, CMhm e CMt apresentaram $>99.2 \%$, $>98.4 \%$ e $>97.8 \%$ de identidade, respectivamente, com sequencias do GenBank. A análise filogenética demonstrou todas as sequencias do Mhf em um único grupo, enquanto as sequencias de CMhm e CMt se agruparam em 3 subgrupos distintos. Estes achados filogenéticos sugerem a existência de diferentes cepas de CMhm e CMt.

Palavras chave: hemoplasmas, Brasil, gatos, prevalência, co-infecções 


\subsection{INTRODUÇÃO}

Hemoplasmas são micoplasmas hemotrópicos que não possuem parede celular e crescem na superfície de eritrócitos podendo causar anemia infecciosa em diferentes espécies de mamíferos. Embora suas características básicas sejam conhecidas (Messick, 2004), nenhuma espécie de hemoplasma foi cultivada in vitro. As três principais espécies que infectam gatos são: Mycoplasma haemofelis (Mhf), 'Candidatus Mycoplasma haemominutum' (CMhm) e 'Candidatus Mycoplasma turicensis' (CMt). Mhf é o mais patogênico, geralmente levando a anemia hemolítica durante a infecção aguda. Em contraste, CMhm e CMt são menos patogênicos, mas em associação com Mhf ou retrovírus podem induzir anemia (Tasker et al., 2009).

Hemoplasmas são encontrados por todo mundo e no Brasil já foram identificados em gatos (Biondo et al., 2009a), cães (Biondo et al., 2009a), gado (Girotto et al., 2012), capivaras (Vieira et al., 2009), leões (Guimaraes et al., 2007) e veados (Grazziotin et al., 2011). Recentemente, o potencial zoonótico dos hemoplasmas foi reportado após a identificação molecular de hemoplasmas em um homem com imunossupressão e outro com exposição frequente a animais infectados por hemoplasmas (dos Santos et al., 2008; Steeret al., 2011; Sykes et al., 2010). Além disso, gatos domésticos podem servir como fonte de hemoplasmas para animais selvagens (André et al., 2014).

A prevalência de hemoplasmas em gatos domésticos de diferentes estados brasileiros já foi reportada em estudos anteriores tais como no Mato 
Grosso do Sul (MS) (36.4\%) (Santis et al., 2014), Rio de Janeiro (RJ) (12\%) (Macieira et al., 2008), Rio Grande do Sul (RS) (21.3\%) (Santos et al., 2009a), Maranhão (MA) (12\%) (Braga et al., 2012), São Paulo (SP) (32\% e 6.5\%) (André et al., 2014; de Bortoli et al., 2012) e Mato Grosso (MT) (8.4\%) (Miceli et al., 2013). Contudo, poucos estudos reportaram achados hematológicos ou analise filogenética. Naqueles em que estudo filogenético foi incluído, apenas pequenas sequencias do gene 16S rRNA (<600pb) foram usadas (Andre et al., 2014; Miceli et al., 2013; Santis et al., 2014) ou as sequencias não foram disponibilizadas no GenBank (Braga et al, 2012). Somado a isso, poucos gatos positivos ou não mais do que duas sequencias de referência para cada espécie de hemoplasma foram utilizadas na analises filogenéticas até então publicadas. Dessa forma, estudos adicionais acerca da filogenia das espécies de hemoplasmas felinos no Brasil são necessários, utilizando sequências do gene 16S rRNA mais completas e/ou outros genes, se possível. Os objetivos deste estudo foram avaliar a prevalência e filogenia dos hemoplasmas de gatos naturalmente infectados de Brasília e cidades satélites, e determinar se há correlação entre infecção por hemoplasmas e alterações hematológicas. 


\subsection{MATERIAL E MÉTODOS}

\section{Coleta das amostras}

De 2009 a 2013, foram colhidas amostras de aproximadamente 2,5ml de sangue em tubos com EDTA de felinos domésticos dos seguintes grupos a fim de adquirir a maior e mais heterogênea população possível: i) gatos da cidade de Brasília e cidades satélites atendidos no Hospital Veterinário da UnB e clínicas locais, ii) gatos domiciliados de 7 cidades satélites (Planaltina, Vicente Pires, Guará, Ceilândia, Samambaia, Taguatinga e Gama) que participaram da campanha de vacinação antirrábica de 2012 e 2013, iii) gatos domiciliados de uma cidade satélite de Sobradinho amostrados durante um programa de levantamento de leishmaniose conduzido pelo serviço de saúde pública, e iv) gatos de um abrigo localizado na periferia de Brasília.

Foram recolhidos dados referentes a gênero mas não sobre a condição de saúde ou idade dos animais.

O projeto foi aprovado pelo comitê de ética da Universidade de Brasília com o número de protocolo UnBDOC n43938/2012.

\section{Análise eritrocitária}

A concentração de hemoglobina e o número de eritrócitos foram determinados em um contador de células veterinário semi-automático ( $A B C$ Vet-Horiba ${ }^{\circledR}$ ABX diagnostics, Brasil) e 0 volume globular (VG) foi determinado pelo método do microhematócrito. O volume corpuscular médio (VCM) e a concentração de hemoglobina corpuscular media ( $\mathrm{CHCM}$ ) foram 
calculados a partir da hemoglobina, VG e número de eritrócitos. Gatos com VG $<24 \%$ foram considerados anêmicos.

\section{Extração de DNA}

DNA foi extraído de $100 \mu l$ de sangue utilizando um kit comercial (Illustra blood genomicPrep Mini Spin Kit, GE Healthcare, UK) de acordo com

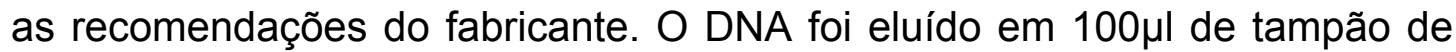
eluição que acompanha o kit e armazenado a $-20^{\circ} \mathrm{C}$ até análise.

\section{PCRs convencionais: GAPDH e de gênero para hemoplasmas}

Todas as amostras foram submetidas a uma PCR convencional para identificação do gene da enzima gliceraldeído-3-fosfato desidrogenase (GAPDH) a fim de verificar a presença de inibidores da PCR e avaliar a qualidade do DNA. A PCR incluiu os oligonucleotídeo descritos por Birkenheuer et al. (2003) e seguiu o seguinte protocolo: $1 \mu \mathrm{L}$ da amostra de DNA foi amplificada usando $0.5 \mu \mathrm{M}$ de cada primer, $1.25 \mathrm{U}$ de Taq DNA Polymerase recombinante, $0.2 \mathrm{mM}$ de dNTPs, $1 \mathrm{X}$ tampão e $1.5 \mathrm{mM} \mathrm{MgCl} 2$ (todos Invitrogen ${ }^{\mathrm{TM}}$ ) com água até completar o volume de $25 \mu \mathrm{L}$. A amplificação foi feita em um termociclador (FTGene5D, Techgene, UK) com desnaturação inicial de $94^{\circ} \mathrm{C}$ por 5 minutos, seguido de 40 ciclos de desnaturação $\left(94^{\circ} \mathrm{C} ; 30\right.$ segundos), anelamento $\left(52^{\circ} \mathrm{C} ; 1\right.$ minuto) e extensão $\left(72^{\circ} \mathrm{C}\right.$; 1 minuto), terminando com extensão final de $72^{\circ} \mathrm{C}$ por 5 minutos. Água foi usada como controle negativo e DNA extraído de um gato saudável foi usado como controle positivo. Amostras com bandas de 400pb após eletroforese em gel de agarose a 1,5\% corado com brometo de etídio foram 
consideradas positivas e, dessa forma, com DNA em qualidade e quantidade suficiente para os próximos testes moleculares.

Após a PCR para GAPDH, as amostras foram testadas para presença de hemoplasmas por meio de uma PCR convencional para o gênero de hemoplasmas adaptada de Criado-Fornelio et al. (2003) que amplifica fragmentos de $595 \mathrm{pb}$ do gene $16 \mathrm{~S}$ rRNA. Na reação, $2 \mu \mathrm{L}$ da amostra de DNA foi amplificada usando $0.5 \mu \mathrm{M}$ de cada primer, $1.0 \mathrm{U}$ de Taq DNA Polymerase recombinante, $0.25 \mathrm{mM}$ de dNTPs, 1X tampão e $2.5 \mathrm{mM}$ de $\mathrm{MgCl}_{2}$ (todos Invitrogen ${ }^{\mathrm{TM}}$ ) com água para completar $25 \mu \mathrm{L}$. A reação foi realizada em um termociclador (FTGene5D, Techgene, UK) com desnaturação inicial de $94^{\circ} \mathrm{C}$ por 10 minutos, seguido por 40 ciclos de desnaturação $\left(94^{\circ} \mathrm{C} ; 30\right.$ segundos $)$, anelamento $\left(50^{\circ} \mathrm{C} ; 30\right.$ segundos) e extensão $\left(72^{\circ} \mathrm{C} ; 30\right.$ segundos), seguidos de extensão final de $72^{\circ} \mathrm{C}$ por 10 minutos. Água foi usada como controle negativo e o DNA de um gato naturalmente infectado por hemoplasma previamente diagnosticado pela citologia de esfregaço e PCR foi usado como controle positivo. Os produtos da PCR foram submetidos a eletroforese em gel de agarose a $1,5 \%$ corado com brometo de etídio. Amostras com fragmentos de $595 \mathrm{pb}$ foram consideradas positivas.

PCRs em tempo real espécie específicas e determinação do número relativo de cópias

Todas as amostras com DNA suficiente e resultados positivos na PCR de gênero para hemoplasmas foram enviadas para a Universidade de Bristol, Inglaterra para subsequente $\mathrm{PCR}$ em tempo real quantitativa (qPCR) 
conforme descrito por Peters et al. (2008b) para identificar as espécies de hemoplasmas (Mhf, CMhm e/ou CMt) presentes e determinar o número relativo de cópias. Todas as reações de qPCR foram combinadas com uma reação de controle interno (gene 28S rRNA felino) para demonstrar a presença de DNA adequado para amplificação e excluir a presença de inibidores; o limite de 22 ciclos ( $\mathrm{Ct}=$ cycle threshold $)$ foi estabelecido para que as amostras fossem consideradas suficientes. Em cada reação, DNA de um gato hemoplasma positivo foi usado como controle positivo e água foi usada como controle negativo.

O número relativo de cópias foi calculado usando a equação $E^{\Delta C t}$, assumindo que o maior $\mathrm{Ct}$ no conjunto de amostras seja 1 cópia de hemoplasma/reação $(\Delta \mathrm{Ct}=$ maior $\mathrm{Ct}$-amostra $\mathrm{Ct})$ e considerando as eficiências de reação $(E)$ das qPCR para Mhf, CMhm e CMt previamente determinadas (Peters et al., 2008b) a partir das curvas padrão.

\section{Sequenciamento do gene 16S rRNA}

Foram selecionadas amostras positivas com os menores $\mathrm{Cts}(11 \mathrm{CMt}$, $10 \mathrm{Mhf}$ e $10 \mathrm{CMhm}$ ) representando diferentes regiões geográficas do DF para amplificação e sequenciamento do gene 16S rRNA. A fim de sequenciar o gene 16S rRNA de cada espécie de hemoplasma nos diversos gatos coinfectados por mais de uma espécie de hemoplasma, foram desenhados oligonucleotídeo espécie específicos para o gene 16S rRNA para amplificar cerca de $1200 \mathrm{pb}$ do gene por meio de uma PCR convencional. Para o desenho dos oligonucleotídeo, sequencias completas do gene 16S rRNA das espécies de hemoplasmas felinos disponíveis no GenBank (números de 
acesso AY831867, DQ157150, DQ157151, DQ464417, DQ464418, DQ464419, DQ464420, DQ464421, DQ464422, DQ464423, DQ464424, DQ464425, AF271154, AY150974, AY150978, AY150979, AY150980, AY150981, U88564, AF178677, AF548631, AY069948, AY150972, AY150976, AY150977, AY150984, AY150985, U88563, U95297) foram selecionadas e alinhadas usando o Clustal-W no programa MacVector versão 13.0.3. A sequencia final resultante da combinação de todas as sequencias disponíveis para a mesma espécie de hemoplasma (sequencia consenso) foi usada para identificar manualmente as regiões mais específicas do gene $16 \mathrm{~S}$ rRNA a partir das quais os oligonucleotídeo poderiam ser obtidos. Pequenas sequencias de $25-30 \mathrm{pb}$ foram selecionadas como oligonucleotídeo forward $\left(5^{\prime}-3^{\prime}\right)$ e reverse (3'-5') e testadas usando o programa Primer3 (web version 4.0.0; http://primer3.ut.ee/) para selecionar os pares de oligonucleotídeo com temperaturas de anelamento adequadas, baixa auto-complementariedade e complementariedade 3' e formação de hairpin.

Dois pares de oligonucleotídeo para cada espécie de hemoplasma foram selecionados baseados no tamanho dos produtos previstos, temperatura de anelamento e baixa complementariedade dos pares (Tabela 1.1). As especificidades dos oligonucleotídeo foram testadas incialmente usando o BLAST contra todas sequencias de DNA existentes no GenBank e em seguida cada par de oligonucleotídeo foi utilizado em uma reação de PCR, cujas amostras incluíram amostras positivas para outras espécies de hemoplasmas em alta concentração $\left(10^{7}\right.$ de CMhm, $10^{7}$ de Mhf ou $10^{4}$ de CMt) para avaliar reações cruzadas. Os oligonucleotídeo selecionados foram testados em uma reação de $25 \mu \mathrm{L}$ contendo $12.5 \mu \mathrm{L}$ do $2 \mathrm{X}$ Promega GoTaq ${ }^{\circledR}$ 
Hot Start Colorless Master Mix (USA) adicionado de $0.2 \mu \mathrm{M}$ de cada oligonucleotídeo e $1 \mu \mathrm{L}$ da amostra de DNA e água para atingir o volume de $25 \mu \mathrm{L}$. A reação foi realizada em um termociclador (SureCycler 8800 - Agilent Technologies, USA) nas seguintes condições: $95^{\circ} \mathrm{C}$ por 5 minutos, seguido de 45 ciclos de amplificação $\left(95^{\circ} \mathrm{C}, 10 \mathrm{~s} ; 62^{\circ} \mathrm{C}, 30 \mathrm{~s} ; 72^{\circ} \mathrm{C} 90 \mathrm{~s}\right) \mathrm{com}$ extensão final de $72^{\circ} \mathrm{C}$ por 5 minutos. Gatos infectados por Mhf, CMt e CMhm individualmente previamente identificados pela qPCR espécie específica e água foram usados como controles positivo e negativo, respectivamente. Os produtos foram identificados por eletroforese em um gel de agarose a $1.5 \%$ corado com brometo de etídio.

Os produtos da PCR com o tamanho esperado de aproximadamente 1200pb foram purificados com o kit NucleoSpin® Gel e PCR Clean-up (MACHEREY NAGEL GmbH \& Co.) de acordo com as recomendações do fabricante, depois quantificados com o fluorometro Qubit ${ }^{\mathrm{TM}}$ (Invitrogen $^{\mathrm{TM}}$ ) e enviados ao serviço de sequenciamento de DNA do MRCPPU, College of Life Sciences, University of Dundee, Scotland (www.dnaseq.co.uk) para sequenciamento usando o Applied Biosystems Big-Dye Ver 3.1 no sequenciador automático por capilaridade Applied Biosystems model 3730. O sequenciamento foi realizado no sentido sense e antisense usando oligonucleotídeos externos específicos (MhfFw2/MhfRev2, CMhmFw2/CMhmRev2, CMtFw2/CMtRev2) e oligonucleotídeos internos (Tabela 1). Os oligonucleotídeo internos foram desenhados manualmente a partir de regiões altamente conservadas do gene 16S rRNA após alinhamento de sequencias do gene 16S rRNA das 3 espécies de hemoplasmas felinos, conferidas e selecionadas usando o Primer3. 


\section{Análise filogenética}

Análise e edição das sequencias foram realizadas no MacVector versão 13.0.3, Inc. A reconstrução das sequências quase completas do gene 16S rRNA das 11 amostras CMt positivas, $10 \mathrm{Mhf}$ positivas e $10 \mathrm{CMhm}$ positivas foi realizada por meio da combinação das sequencias individuais provenientes dos oligonucleotídeo internos e externos. As novas sequencias do gene $16 \mathrm{~S}$ rRNA produzidas neste estudo e as sequencias do mesmo gene disponíveis no GenBank foram alinhadas usando o Clustal-W. A árvore filogenética foi gerada usando o método de Neighbor-Joining a partir da distância P da matriz e os dados foram reorganizados 1000 vezes para estimar a confiança nos padrões de ramificação.

As novas sequencias do gene $16 \mathrm{~S}$ rRNA geradas neste estudo foram submetidas ao GenBank com os seguintes números de acesso: sequencias Mhf (KM275238-KM275247), sequencias CMhm (KM275248-KM275257) e sequencias CMt (KM275258-KM275268).

\section{Análise estatística}

A fim de determinar com maior precisão a prevalência dos hemoplasmas na região do DF, o tamanho da amostra necessária foi estimada de acordo com Thrusfield (1986) com base em evidencias previamente publicadas (Biondo et al., 2009b; Barker et al., 2010) com precisão de $5 \%$ e intervalos de confiança de $95 \%$.

Os dados foram computados no Excel囚 e a avaliação estatística foi realizada no programa SPSS para Windows (SPSS Inc., Chicago IL, USA). As prevalências das variáveis categóricas (gênero, resultado das PCRs 
convencional e em tempo real) foram calculadas com intervalos de confiança de $95 \%$ usando o método binomial exato de Clopper-Pearson e as diferenças foram analisadas por meio do teste $x^{2}$. Os gatos foram divididos em 5 grupos de acordo com o resultado da qPCR: gatos hemoplasma negativo, gatos infectados por CMhm apenas, gatos co-infectados por CMhm e Mhf, gatos co-infectados por CMhm e CMt, e gatos co-infectados pro CMhm, Mhf e CMt (nenhum gato infectado apenas por Mhf ou CMt foi encontrado). O teste Kolmogorov-Smirnov foi usado para testar a distribuição normal das variáveis contínuas (VG, número de eritrócitos, concentração de hemoglobina, VCM e CHCM). O teste Kruskal-Wallis foi usado para determinar se havia qualquer diferença significante entre os grupos de gatos para as variáveis hematológicas contínuas não normalmente distribuídas. O teste de Spearman foi usado para avaliar a correlação em dados não normalmente distribuídos. Valores de $p>0.05$ foram considerados estatisticamente significantes. 


\subsection{RESULTADOS}

Foi estimado que uma amostra de 349 gatos seria necessária para determinar a prevalência dos hemoplasma em felinos em Brasília e cidades satélites. De 2009 a 2013, 451 amostras foram coletadas.

Os resultados da PCR convencional para gênero de hemoplasmas e da qPCR espécie específica estão resumidas na tabela 1.2. Todas as 451 amostras foram positivas na PCR para GAPDH. Dos 451 gatos amostrados, $80(17,7 \%)$ foram positivos na PCR de gênero para hemoplasmas. Porém, devido ao pequeno volume de algumas amostras, apenas 61 dessas 80 amostras positivas para hemoplasmas foram submetidas a qPCR espécie específica. Dessa forma, 432 gatos formaram a população final deste estudo. Dados sobre o gênero não estavam disponíveis para 70 gatos; dos 362 gatos restantes, $176(48,6 \%)$ eram fêmeas e $186(51,3 \%)$ eram machos. Todas as 61 amostras testadas pela qPCR foram positivas para o gene 28S rRNA com Cts de $\leq 22$. Sessenta das 61 amostras foram positivas para alguma espécie de hemoplasma, gerando uma prevalência total de $13,8 \%$ dos 432 gatos. Apenas um gato foi positivo na PCR convencional de gênero para hemoplasmas e negativo na qPCR espécie específica. Dos 432 gatos, 48 foram positivos para Mhf, 60 para CMhm e 19 para CMt, representando prevalências de $11,1 \%, 13,8 \%$ e 4,4\% respectivamente para cada espécie de hemoplasma. A prevalência de CMt foi significativamente menor $(p=0.0002)$ do que as prevalências de Mhf e CMhm, mas não houve diferença significativa entre as prevalências de CMhm e Mhf (tabela 2). Observou-se uma grande proporção de gatos co-infectados por duas ou três espécies de 
hemoplasma. Cinquenta dos $60(83 \%)$ gatos infectados por hemoplasmas estavam infectados por mais de uma espécie e nenhum gato infectado apenas por Mhf ou CMt foi encontrado. Dos 432 gatos, $17(3,9 \%)$ apresentaram infecção concomitante pelas 3 espécies de hemoplasmas, 31 (7,1\%) apresentaram infecção dupla por Mhf e CMhm, e dois gatos $(0,4 \%)$ apresentaram infecção dupla por CMhm e CMt (figura 1.2). Todos os controles positivos e negativos apresentaram resultados esperados em todas as PCRs.

Observou-se correlação estatisticamente significativa entre os resultados das PCRs e o gênero dos gatos. Gatos machos apresentaram maior prevalência na PCR de gênero para hemoplasmas $(p=0,01)$ e foram mais positivos para Mhf $(p=0,004)$, CMhm $(p=0,009)$ e CMt $(p=0,03)$ do que gatas fêmeas.

Uma ampla variação no número relativo de cópias foi observado para as três espécies de hemoplasmas: gatos infectados por Mhf apresentaram número relativo de cópias variando de $0.2 \times 10^{0}$ a $2.54 \times 10^{8}$ cópias relativas/ $\mu$ l de sangue; os gatos infectados por $\mathrm{CMhm}$ apresentaram variação de $0.2 \times 10^{0}$ a $2.32 \times 10^{8} / \mu$ l e gatos infectados por CMt apresentaram número de cópias variando de $0.2 \times 10^{0}$ a $1.38 \times 10^{8} / \mu \mathrm{l}$ (Figura 1.1)

Os dados hematológicos (VG, número de células vermelhas, concentração de hemoglobina, VCM e $\mathrm{CHCM}$ ) não seguiram distribuição normal (tabela 1.3) e estavam disponíveis em 420 gatos amostrados. Não houve diferença significativa para os parâmetros hematológicos entre os gatos agrupados de acordo com o resultado das PCRs (tabela 1.3). Não houve correlação significativa entre a concentração de hemoglobina e o 
número relativo de cópias do $\operatorname{Mhf}\left(n=45, r_{s}=0.127, p=0.4\right)$, CMhm $(n=57$, $\left.r_{s}=0.246, p=0.065\right)$ ou CMt $\left(n=17, r_{s}=-0.032, p=0.903\right)$, embora a correlação foi quase significativa para o CMhm. Testes de correlação entre VG e o número relativo de cópias de $\operatorname{Mhf}\left(n=45, r_{s}=0.031, p=0.837\right)$, CMhm $(n=57$, $\left.r_{s}=0.294, p=0.027\right)$ ou CMt $\left(n=17, r_{s}=-0.101, p=0.7\right)$ mostrou correlação significante apenas para $\mathrm{CMhm}$. O mesmo resultado foi observado para o teste de correlação com o número de eritrócitos (Mhf [n=45, $r_{s}=0.048$, $p=0.752], C M h m\left[n=57, r_{s}=0.276, p=0.038\right]$ or $\left.C M t\left[n=17, r_{s}=-0.032, p=0.9\right]\right)$. Devido ao pequeno número de gatos co-infectados por $\mathrm{CMhm}$ e $\mathrm{CMt}$, nenhuma análise estatística desse grupo foi possível.

Todos os 6 pares de oligonucleotídeos espécie específicos para o gene 16S rRNA selecionados para PCR convencional e sequenciamento amplificaram o fragmento previsto. Os pares de oligonucleotídeos selecionados para amplificar e sequenciar cada hemoplasma espécie (tabela 1.1) foram escolhidos devido a não amplificação de outras espécies de hemoplasma que não a selecionada e a ausência de formação de dímeros.

A comparação das sequencias Mhf geradas no presente estudo revelou que essas sequencias compartilham similaridade $>99.8 \%$, para as sequencias de CMhm essa similaridade foi $>98.5 \%$ e $>98.8 \%$ entre as sequencias de CMt. O alinhamento das sequencias geradas neste estudo e aquelas disponíveis no GenBank revelou identidade de 99.2\%-100\% para Mhf, $98.4 \%-100 \%$ para CMhm e $97.8 \%-100 \%$ para CMt.

As relações filogenéticas das sequencias geradas neste estudo e aquelas disponíveis no GenBank estão representadas na figura 1.2. Esta análise gerou a separação esperada das sequencias em três grupos 
distintos, um para cada espécie de haemoplasma, acompanhados por altos valores de bootstrap. Todas as sequencias de Mhf se agruparam em um único grupo com as outras sequencias de Mhf provenientes de outros estudos de gatos domésticos e selvagens. Porém, as sequencias de CMhm dividiram-se em 3 subgrupos. Os subgrupos 1 e 2 incluíram oito das dez sequencias de CMhm deste estudo e estavam mais próximas de sequencias de hemoplasmas de gatos selvagens da África, Brasil e Espanha; e o subgrupo 3 consistiu de 2 sequencias que compartilharam proximidade evolutiva com sequencias de hemoplasmas de gatos domésticos da Europa (Reino Unido e Suíça). A análise filogenética das sequencias de CMt também apresentou divisão em 3 subgrupos: 5 das 11 sequencias de CMt deste estudo ficaram agrupadas nos subgrupos 1 e 2, que estavam mais relacionados com sequencias de gatos domésticos da Austrália e África, enquanto as sequencias de CMt do subgrupo 3 estavam mais próximas de sequencias de gatos domésticos e selvagens de países europeus (Suíça, Reino Unido e França). 


\subsection{DISCUSSÃO}

As três espécies de hemoplasma felinos foram encontradas em gatos domésticos de Brasília e cidades satélites. A prevalência geral foi similar àquelas encontradas nos estados brasileiros do RJ (Macieira et al., 2008), MA (Braga eta I., 2012), SP (de Bortoli et al., 2012), MT (Miceli et al., 2013) e em estudos do Reino Unido (Tasker et al., 2003a) e Itália (Gentilini et al., 2009). Porém, estudos conduzidos em gatos não domiciliados de outros estados brasileiros (André et al., 2014; Santis et al., 2014; Santos et al., 2009b), Portugal (Martínez-Díaz et al., 2013) e Itália (Spada et al., 2014) reportaram prevalências maiores do que a encontrada no presente estudo. As prevalências individuais de $\mathrm{CMhm}$ e $\mathrm{CMt}$ foram similares aquelas encontradas em estudos brasileiros prévios (André et al., 2014; Braga et al., 2012; Macieira et al., 2008; Miceli et al., 2013; Santis et al., 2014; Santos et al., 2009b), contudo, a prevalência de Mhf foi maior do que a previamente reportada no RS (Santos et al., 2009a), MA (Braga et al., 2012) e MT (Miceli et al., 2013). Conforme esperado, as prevalências encontradas neste estudo foram menores do que aquelas encontradas em estudos internacionais que amostraram gatos pacientes de clinicas veterinárias ou com suspeita de hemoplasmose (Jenkins et al., 2013; Lobetti e Lappin, 2012; Spada et al., 2014; Sykes et al., 2007); mas as prevalências do presente estudo foram maiores do que aquelas encontradas em gatos clinicamente saudáveis usados como doadores de sangue (Hackett et al., 2006).

As diferenças observadas entre as prevalências reportadas anteriormente e as encontradas no presente estudo podem refletir variações 
nos grupos de gatos estudados e os fatores de risco para infecção por hemoplasmas. As populações de gatos dos estudos brasileiros prévios eram diversas e incluíram gatos de vida livre (André et al., 2014; Santis et al., 2014), gatos domesticados incluídos em programas de castração (de Bortoli et al., 2012; Santis et al., 2014), gatos atendidos em uma clínica exclusiva para felinos e hospitais veterinários locais (Macieira et al., 2008; Santos et al., 2009a), gatos domesticados doadores de sangue (Santos et al., 2009a), gatos de abrigos (Miceli et al., 2013; Santos et al., 2009a) e gatos domesticados com acesso a rua (Braga et al., 2012). O contato direto com gatos não domiciliados de rua no ambiente externo é considerado um fator de risco para a infecção por hemoplasmas (Willi et al., 2006a). Gatos não domiciliados que vivem na rua possuem mais risco de serem infectados por hemoplasmas devido a brigas, porém o número de gatos não domiciliados de rua incluídos no presente estudo foi baixo, representando $9,3 \%$ da população estudada e dados referentes ao acesso a rua não foram disponibilizados para os gatos domiciliados. Além disso, é esperado que infecção por hemoplasma seja encontrada com maior frequência em gatos amostrados de clinicas e hospitais veterinários devido a sua condição de saúde. Diferenças regionais como o clima, e, consequentemente, o tempo e frequência de exposição a ectoparasitos, podem influenciar na prevalência final dos hemoplasmas (Willi et al., 2006a). Contudo, a comparação direta entre estudos é arriscada quando há diferenças em fatores como critérios de inclusão, clima local, inclusão de animais com acesso a rua ou não, assim como o teste de PCR usado no diagnóstico. O presente estudo é o primeiro a reportar a 
prevalência de hemoplasmas em gatos do Brasil usando qPCR como ferramenta diagnóstica.

No presente estudo, mais de $80 \%$ dos gatos hemoplasma positivos (50 de 60 gatos) estavam co-infectados por mais de uma espécie de hemoplasma. Embora muitos autores já tenham reportado gatos com infecção dupla ou tripla por hemoplasmas (André et al., 2014; de Bortoli et al., 2012; Santis et al., 2014), a proporção de gatos co-infectados no presente estudo foi significativamente maior do que previamente reportado no RS (16\%) (Santos et al., 2009a), MS (45\%) (Santis et al., 2014), RJ (16,6\%) (Macieira et al., 2008), MA (20,8\%) (Braga et al., 2012), SP (33,3\%) (André et al., 2014; de Bortoli et al., 2012) e MT (6,6\%)(Miceli et al., 2013). A presença de muitas co-infecções triplas e duplas no presente estudo pode estar relacionado com 0 fato de diferentes espécies de hemopasmas compartilharem fatores de risco e/ou formas semelhantes de transmissão. Associado a isso está o fato de gatos infectados por uma espécie de hemoplasma poderem apresentar maior susceptibilidade a infecção por outras espécies de hemoplasmas (Willi et al., 2006a), pois uma correlação entre CMt e Mhf e entre CMt e CMhm já foi relatada anteriormente (Willi et al., 2006b).

Apenas um gato foi positivo na PCR genérica para hemoplasmas e negativo na qPCR espécie específica. Essa amostra poderia ter baixo número de cópias de hemoplasmas, abaixo do limite de sensibilidade da qPCR (Sykes et al., 2007) ou poderia se tratar de uma nova espécie de hemoplasma com mutações na região de ligação dos oligonucleotídeos e probes. Um resultado falso positivo na PCR genérica para hemoplasmas não 
pode ser descartada, embora os controles negativos funcionaram adequadamente em todos os testes. O ideal seria amplificar essa mesma amostra com uma PCR de gênero de hemoplasmas alternativa (Tasker et al., 2010) e em seguida sequenciar os produtos, contudo essa amostra não tinha DNA suficiente para testes adicionais.

Estudos sobre os fatores de risco associados com hemoplasmas (Jenkins et al., 2013; Tasker et al., 2003a; Willi et al., 2006a) encontraram que gatos machos têm mais chances de serem infectados por hemoplasmas do que fêmeas, o que está de acordo com os achados do presente estudo. A maior prevalência por hemoplasmas em machos pode estar associada com maiores chances de infecção frente aos padrões de comportamento dos machos, tais como acesso a rua, mordidas e brigas. De fato, é possível que hemoplasmas sejam transmitidos de forma direta conforme sugerido após a detecção de DNA de CMt e CMhm na saliva de gatos infectados por essas espécies (Dean et al., 2008; Museux et al., 2009), embora acredita-se que uma interação agressiva seja necessária, pois a forma direta de transmissão de hemoplasmas requer a exposição a sangue contaminado por hemoplasmas ao invés de apenas saliva (Museux et al., 2009). Da mesma forma, outros patógenos diretamente transmitidos por meio de brigas, tais como o vírus da imunodeficiência felina (FIV), podem induzir imunossupressão que favorece a infecção por hemoplasmas (Jenkins et al., 2013). Infelizmente não foi possível avaliar a presença de retrovírus nos gatos incluídos no presente estudo.

Estudos anteriores observaram que gatos infectados por hemoplasmas tinham mais chances de serem anêmicos do que gatos 
negativos (Lobetti e Tasker, 2004; Tasker et al., 2004; Tasker et al., 2009; Willi et al., 2005), principalmente nas infecções por Mhf (Gentilini et al., 2009; Jenkins et al., 2013; Lobetti e Lappin, 2012; Lobetti e Tasker, 2004). Porém, o presente estudo, assim como outros (Barker et al., 2010; Bauer et al., 2008; Macieira et al., 2008; Martínez-Díaz et al., 2013; Spada et al., 2014; Wengi et al., 2008; Willi et al., 2006a) não encontrou associação entre infecção por hemoplasmas e anemia. Conforme sugerido por Sykes (2010) e Willi et al. (2006a), as mudanças nos parâmetros hematológicos durante a infecção por hemoplasmas variam de acordo com o estágio da infecção (agudo x crônico), a espécie de hemoplasma presente, diferentes patogenicidades das espécies de hemoplasmas, variação de cepas de uma mesma espécie de hemoplasma e fatores associados ao hospedeiro, tais como idade. O estágio da infecção dos gatos avaliados no presente estudo era desconhecido, uma vez que foram amostrados gatos naturalmente infectados e a idade não foi incluída no banco de dados, porque a maioria dos proprietários participantes não sabia a data de nascimento dos animais.

Willi et al. (2006b) sugeriu que a anemia tende a estar presente em gatos co-infectados por mais de uma espécie de hemoplasma, como um efeito aditivo de diferentes espécies na doença clínica. No entanto, o grupo de gatos co-infectados do presente estudo não apresentou parâmetros hematológicos significativamente inferiores àqueles dos gatos infectados por uma única espécie de hemoplasma ou àqueles gatos não infectados (tabela 3), similar ao que já foi relatado anteriormente (Willi et al., 2006a). Da mesma forma, alterações hematológicas em gatos co-infectados por múltiplas espécies de hemoplasmas também podem ser influenciadas pelos mesmos 
fatores (por exemplo, estágio da infecção) propostos anteriormente para infecções por apenas uma espécie de hemoplasma.

Como apenas gatos naturalmente infectados foram amostrados no presente estudo e muitos estavam co-infectados por mais de uma espécie de hemoplasma, não foi possível avaliar qual ou quais espécies de hemoplasma fez a primeira infecção. Dessa forma, não foi possível avaliar quais efeitos uma espécie de hemoplasma teve na presença das outras espécies, ou como a ordem de infecção pode ter afetado os parâmetros hematológicos e o número de cópias dos hemoplasmas infectantes.

Gatos infectados concomitantemente por duas ou três espécies de hemoplasmas foram comuns no presente estudo, o que impossibilitou o uso de oligonucleotídeos universais para amplificação e sequenciamento do gene 16S rRNA para cada uma das espécies de hemoplasmas nesses gatos. $O$ desenho de novos oligonucleotídeos espécie específicos para o gene $16 \mathrm{~S}$ rRNA tornou possível o sequenciamento individual das espécies de hemoplasma de 12 gatos com infecção tripla e 10 gatos com infecção dupla por hemoplasmas (figura 1.2). Esse é o primeiro estudo a usar essa abordagem para obter sequencias de hemoplasmas individualmente de gatos com co-infecções.

A análise filogenética baseada no gene 16S rRNA demonstrou a separação das sequencias obtidas em três grupos distintos, um para cada espécie de hemoplasma (figura 1.2). As sequencias das espécies CMhm e CMt apresentaram divisões adicionais em subgrupos, conforme observado anteriormente por Tasker et al. (2003b) e Willi et al. (2006b), apesar de outros estudos filogenéticos de hemoplasmas não terem apresentado a mesma 
subdivisão (Braga et al., 2012; Miceli et al., 2013; Santis et al., 2014). É digno de nota o fato de as sequencias de CMhm agrupadas no subgrupo 2 (figura 2) serem similares a sequencias derivadas de leões africanos que também apresentaram alta frequência de co-infecções por diferentes espécies de hemoplasma (Willi et al., 2007). Porém, ressalta-se que nem todas as sequencias de CMhm incluídas no subgrupo 2 eram de gatos com coinfecção, uma vez que 2 dos 7 gatos desse subgrupo apresentaram infecção por CMhm apenas, o que nos leva a crer que o agrupamento visto na filogenia não está totalmente associado com co-infecções por hemoplasmas. A formação de subgrupos dentro das sequencias de CMhm e CMt demonstrou um agrupamento por diferentes regiões do mundo e por diferentes espécies de hospedeiro (felinos doméstico $x$ felinos selvagens). Considerando que divergências filogenéticas podem refletir diferenças fenotípicas (Tasker et al., 2001), nossos achados sugerem a existência de diferentes cepas de hemoplasmas, que podem estar relacionadas com diferentes patogenicidades, distribuição geográfica ou espécies de hospedeiro. Contudo, ainda não existe uma definição precisa do que é uma cepa de espécie de hemoplasma.

Diferente do que se observou nas sequencias de CMhm e CMt e conforme anteriormente observado (Braga et al., 2012; Tasker et al., 2003b; Willi et al., 2007), as sequencias de Mhf geradas no presente estudo não apresentaram formação de subgrupos. A razão para essa diferença na estabilidade do gene 16S rRNA nesta espécie de hemoplasma ainda é desconhecida. 
Embora a informação filogenética derivada de um gene altamente conservado, como o $16 \mathrm{~S}$ rRNA, seja usada com frequência, a obtenção de dados filogenéticos de genes diferentes, tais como relatado em outros estudos (Hicks et al., 2014; Peters et al., 2008a; Tasker et al., 2003b), teria contribuído para as conclusões do presente estudo. Porém, o grande número de gatos co-infectados por mais de uma espécie de hemoplasma dificultou a amplificação de outros genes, tais como o gene RNase P RNA, uma vez que o desenho de oligonucleotídeo espécie específicos foi impossibilitado frente ao tamanho pequeno desse gene.

Avaliações futuras com maior número de genes, de casos e utilizando métodos alternativos poderiam contribuir para refinar e esclarecer os achados descritos na presente avaliação filogenética. 


\subsection{CONCLUSÃO}

Este é o primeiro estudo a caracterizar a nível molecular sequencias quase completas do gene 16S rRNA de hemoplasmas infectando gatos domésticos com alta prevalência de co-infecções usando novos oligonucleotídeo espécie específicos. Variáveis hematológicas também foram avaliadas. Estudos futuros deveriam investigar a significância de co-infecções em felinos domésticos e selvagens dentro da epidemiologia das infecções por hemoplasmas.

\section{Agradecimentos}

Agradecemos a CAPES pela bolsa do doutorado e sanduíche de Larissa Campos Aquino, aos residentes do Laboratório de Patologia Clinica Veterinária da UnB pelo grande apoio técnico neste estudo, a School of Veterinary Sciences and the Molecular Diagnostic Unit, Langford Veterinary Services da Universidade de Bristol pelo apoio intelectual e técnico. Nosso muito obrigado aos proprietários que permitiram que seus gatos fossem incluídos neste estudo. Chelsea Hicks teve o apoio financeiro durante seu doutorado da BBSRC e Zoetis Animal Health. 


\section{REFERÊNCIAS BIBLIOGRÁFICAS}

André, M.R., Baccarim Denardi, N.C., Marques de Sousa, K.C., Gonçalves, L.R., Henrique, P.C., Grosse Rossi Ontivero, C.R., Lima Gonzalez, I.H., Cabral Nery, C.V., Fernandes Chagas, C.R., Monticelli, C., Alexandre de Santis, A.C., Machado, R.Z., 2014. Arthropod-borne pathogens circulating in free-roaming domestic cats in a zoo environment in Brazil. Ticks Tick Borne Dis.

Barker, E.N., Tasker, S., Day, M.J., Warman, S.M., Woolley, K., Birtles, R., Georges, K.C., Ezeokoli, C.D., Newaj-Fyzul, A., Campbell, M.D., Sparagano, O.A., Cleaveland, S., Helps, C.R., 2010. Development and use of real-time PCR to detect and quantify Mycoplasma haemocanis and "Candidatus Mycoplasma haematoparvum" in dogs. Vet Microbiol 140, 167-170.

Bauer, N., Balzer, H.J., Thüre, S., Moritz, A., 2008. Prevalence of feline haemotropic mycoplasmas in convenience samples of cats in Germany. J Feline Med Surg 10, 252-258.

Biondo, A.W., Dos Santos, A.P., Guimaraes, A.M., Vieira, R.F., Vidotto, O., Macieira Dde, B., Almosny, N.R., Molento, M.B., Timenetsky, J., de Morais, H.A., Gonzalez, F.H., Messick, J.B., 2009a. A review of the occurrence of hemoplasmas (hemotrophic mycoplasmas) in Brazil. Rev Bras Parasitol Vet 18, 1-7.

Biondo, A.W., Dos Santos, A.P., Guimarães, A.M., Vieira, R.F., Vidotto, O., Macieira, D.e.B., Almosny, N.R., Molento, M.B., Timenetsky, J., de Morais, H.A., González, F.H., Messick, J.B., 2009b. A review of the occurrence of hemoplasmas (hemotrophic mycoplasmas) in Brazil. Rev Bras Parasitol Vet 18, 1-7.

Birkenheuer, A.J., Levy, M.G., Breitschwerdt, E.B., 2003. Development and evaluation of a seminested PCR for detection and differentiation of Babesia gibsoni (Asian genotype) and B. canis DNA in canine blood samples. J Clin Microbiol 41, 4172-4177.

Braga, M.S., André, M.R., Freschi, C.R., Teixeira, M.C., Machado, R.Z., 2012. Molecular detection of hemoplasma infection among cats from São Luís island, Maranhão, Brazil. Braz J Microbiol 43, 569-575.

Criado-Fornelio, A., Martinez-Marcos, A., Buling-Saraña, A., Barba-Carretero, J.C., 2003. Presence of Mycoplasma haemofelis, Mycoplasma haemominutum and piroplasmids in cats from southern Europe: a molecular study. Vet Microbiol 93, 307-317.

de Bortoli, C.P., André, M.R., Seki, M.C., Pinto, A.A., Machado, S.e.T., Machado, R.Z., 2012. Detection of hemoplasma and Bartonella species and co-infection with retroviruses in cats subjected to a 
spaying/neutering program in Jaboticabal, SP, Brazil. Rev Bras Parasitol Vet 21, 219-223.

Dean, R.S., Helps, C.R., Gruffydd Jones, T.J., Tasker, S., 2008. Use of realtime PCR to detect Mycoplasma haemofelis and 'Candidatus Mycoplasma haemominutum' in the saliva and salivary glands of haemoplasma-infected cats. J Feline Med Surg 10, 413-417.

dos Santos, A.P., dos Santos, R.P., Biondo, A.W., Dora, J.M., Goldani, L.Z., de Oliveira, S.T., de Sá Guimarães, A.M., Timenetsky, J., de Morais, H.A., González, F.H., Messick, J.B., 2008. Hemoplasma infection in HIV-positive patient, Brazil. Emerg Infect Dis 14, 1922-1924.

Gentilini, F., Novacco, M., Turba, M.E., Willi, B., Bacci, M.L., HofmannLehmann, R., 2009. Use of combined conventional and real-time PCR to determine the epidemiology of feline haemoplasma infections in northern Italy. J Feline Med Surg 11, 277-285.

Girotto, A., Zangirolamo, A.F., Bogado, A.L., Souza, A.S., da Silva, G.C., Garcia, J.L., Vilas Boas, L.A., Biondo, A.W., Vidotto, O., 2012. Molecular detection and occurrence of 'Candidatus Mycoplasma haemobos' in dairy cattle of Southern Brazil. Rev Bras Parasitol Vet 21, 342-344.

Grazziotin, A.L., Santos, A.P., Guimaraes, A.M., Mohamed, A., Cubas, Z.S., de Oliveira, M.J., dos Santos, L.C., de Moraes, W., Vieira, R.F., Donatti, L., de Barros Filho, I.R., Biondo, A.W., Messick, J.B., 2011. Mycoplasma ovis in captive cervids: prevalence, molecular characterization and phylogeny. Vet Microbiol 152, 415-419.

Guimaraes, A.M., Javorouski, M.L., Bonat, M., Lacerda, O., Balbinotti, B., Queiroz, L.G., Timenetsky, J., Biondo, A.W., Messick, J.B., 2007. Molecular detection of "Candidatus Mycoplasma haemominutum" in a lion (Panthera leo) from a Brazilian zoological garden. Rev Inst Med Trop Sao Paulo 49, 195-196.

Hackett, T.B., Jensen, W.A., Lehman, T.L., Hohenhaus, A.E., Crawford, P.C., Giger, U., Lappin, M.R., 2006. Prevalence of DNA of Mycoplasma haemofelis, 'Candidatus Mycoplasma haemominutum,' Anaplasma phagocytophilum, and species of Bartonella, Neorickettsia, and Ehrlichia in cats used as blood donors in the United States. J Am Vet Med Assoc 229, 700-705.

Hicks, C.A., Barker, E.N., Brady, C., Stokes, C.R., Helps, C.R., Tasker, S., 2014. Non-ribosomal phylogenetic exploration of Mollicute species: new insights into haemoplasma taxonomy. Infection, genetics and evolution : journal of molecular epidemiology and evolutionary genetics in infectious diseases 23, 99-105. 
Jenkins, K.S., Dittmer, K.E., Marshall, J.C., Tasker, S., 2013. Prevalence and risk factor analysis of feline haemoplasma infection in New Zealand domestic cats using a real-time PCR assay. J Feline Med Surg 15, 1063-1069.

Lobetti, R., Lappin, M.R., 2012. Prevalence of Toxoplasma gondii, Bartonella species and haemoplasma infection in cats in South Africa. J Feline Med Surg 14, 857-862.

Lobetti, R.G., Tasker, S., 2004. Diagnosis of feline haemoplasma infection using a real-time PCR assay. J S Afr Vet Assoc 75, 94-99.

Macieira, D.B., de Menezes, R.e.C., Damico, C.B., Almosny, N.R., McLane, H.L., Daggy, J.K., Messick, J.B., 2008. Prevalence and risk factors for hemoplasmas in domestic cats naturally infected with feline immunodeficiency virus and/or feline leukemia virus in Rio de Janeiro-Brazil. J Feline Med Surg 10, 120-129.

Martínez-Díaz, V.L., Silvestre-Ferreira, A.C., Vilhena, H., Pastor, J., Francino, O., Altet, L., 2013. Prevalence and co-infection of haemotropic mycoplasmas in Portuguese cats by real-time polymerase chain reaction. J Feline Med Surg 15, 879-885.

Messick, J.B., 2004. Hemotrophic mycoplasmas (hemoplasmas): a review and new insights into pathogenic potential. Vet Clin Pathol 33, 2-13.

Miceli, N.G., Gavioli, F.A., Gonçalves, L.R., André, M.R., Sousa, V.R., Sousa, K.C., Machado, R.Z., 2013. Molecular detection of feline arthropodborne pathogens in cats in Cuiabá, state of Mato Grosso, centralwestern region of Brazil. Rev Bras Parasitol Vet 22, 385-390.

Museux, K., Boretti, F.S., Willi, B., Riond, B., Hoelzle, K., Hoelzle, L.E., Wittenbrink, M.M., Tasker, S., Wengi, N., Reusch, C.E., Lutz, H., Hofmann-Lehmann, R., 2009. In vivo transmission studies of 'Candidatus Mycoplasma turicensis' in the domestic cat. Vet Res 40, 45.

Peters, I.R., Helps, C.R., McAuliffe, L., Neimark, H., Lappin, M.R., GruffyddJones, T.J., Day, M.J., Hoelzle, L.E., Willi, B., Meli, M., HofmannLehmann, R., Tasker, S., 2008a. RNase P RNA gene (rnpB) phylogeny of Hemoplasmas and other Mycoplasma species. J Clin Microbiol 46, 1873-1877.

Peters, I.R., Helps, C.R., Willi, B., Hofmann-Lehmann, R., Tasker, S., 2008b. The prevalence of three species of feline haemoplasmas in samples submitted to a diagnostics service as determined by three novel realtime duplex PCR assays. Vet Microbiol 126, 142-150.

Santis, A.C., Herrera, H.M., Sousa, K.C., Goncalves, L.R., Denardi, N.C., Domingos, I.H., Campos, J.B., Machado, R.Z., Andre, M.R., 2014. 
Molecular detection of hemotrophic mycoplasmas among domiciled and free-roaming cats in Campo Grande, state of Mato Grosso do Sul, Brazil. Rev Bras Parasitol Vet 23, 231-236.

Santos, A.P., Messick, J.B., Biondo, A.W., Oliveira, S.T., Pedralli, V., Lasta, C.S., Lacerda, L.A., Esteves, V.S., Hofmann-Lehmann, R., Willi, B., Gonzalez, F.H., 2009a. Design, optimization, and application of a conventional PCR assay with an internal control for detection of 'Candidatus Mycoplasma turicensis' 16S rDNA in domestic cats from Brazil. Vet Clin Pathol 38, 443-452.

Santos, A.P., Messick, J.B., Biondo, A.W., Oliveira, S.T., Pedralli, V., Lasta, C.S., Lacerda, L.A., Esteves, V.S., Hofmann-Lehmann, R., Willi, B., González, F.H., 2009b. Design, optimization, and application of a conventional PCR assay with an internal control for detection of 'Candidatus Mycoplasma turicensis' 16S rDNA in domestic cats from Brazil. Vet Clin Pathol 38, 443-452.

Spada, E., Proverbio, D., Galluzzo, P., Della Pepa, A., Bagnagatti De Giorgi, G., Perego, R., Ferro, E., 2014. Prevalence of haemoplasma infections in stray cats in northern Italy. ISRN Microbiol 2014, 298352.

Steer, J.A., Tasker, S., Barker, E.N., Jensen, J., Mitchell, J., Stocki, T., Chalker, V.J., Hamon, M., 2011. A novel hemotropic Mycoplasma (hemoplasma) in a patient with hemolytic anemia and pyrexia. Clin Infect Dis 53, e147-151.

Sykes, J.E., 2010. Feline hemotropic mycoplasmas. Vet Clin North Am Small Anim Pract 40, 1157-1170.

Sykes, J.E., Drazenovich, N.L., Ball, L.M., Leutenegger, C.M., 2007. Use of conventional and real-time polymerase chain reaction to determine the epidemiology of hemoplasma infections in anemic and nonanemic cats. J Vet Intern Med 21, 685-693.

Sykes, J.E., Lindsay, L.L., Maggi, R.G., Breitschwerdt, E.B., 2010. Human coinfection with Bartonella henselae and two hemotropic mycoplasma variants resembling Mycoplasma ovis. J Clin Microbiol 48, 3782-3785.

Tasker, S., Binns, S.H., Day, M.J., Gruffydd-Jones, T.J., Harbour, D.A., Helps, C.R., Jensen, W.A., Olver, C.S., Lappin, M.R., 2003a. Use of a PCR assay to assess the prevalence and risk factors for Mycoplasma haemofelis and 'Candidatus Mycoplasma haemominutum' in cats in the United Kingdom. Vet Rec 152, 193-198.

Tasker, S., Braddock, J.A., Baral, R., Helps, C.R., Day, M.J., Gruffydd-Jones, T.J., Malik, R., 2004. Diagnosis of feline haemoplasma infection in Australian cats using a real-time PCR assay. J Feline Med Surg 6, 345354. 
Tasker, S., Helps, C.R., Belford, C.J., Birtles, R.J., Day, M.J., Sparkes, A.H., Gruffydd-Jones, T.J., Harbour, D.A., 2001. 16S rDNA comparison demonstrates near identity between an United Kingdom Haemobartonella felis strain and the American California strain. Vet Microbiol 81, 73-78.

Tasker, S., Helps, C.R., Day, M.J., Harbour, D.A., Shaw, S.E., Harrus, S., Baneth, G., Lobetti, R.G., Malik, R., Beaufils, J.P., Belford, C.R., Gruffydd-Jones, T.J., 2003b. Phylogenetic analysis of hemoplasma species: an international study. J Clin Microbiol 41, 3877-3880.

Tasker, S., Peters, I.R., Mumford, A.D., Day, M.J., Gruffydd-Jones, T.J., Day, S., Pretorius, A.M., Birtles, R.J., Helps, C.R., Neimark, H., 2010. Investigation of human haemotropic Mycoplasma infections using a novel generic haemoplasma qPCR assay on blood samples and blood smears. Journal of medical microbiology 59, 1285-1292.

Tasker, S., Peters, I.R., Papasouliotis, K., Cue, S.M., Willi, B., HofmannLehmann, R., Gruffydd-Jones, T.J., Knowles, T.G., Day, M.J., Helps, C.R., 2009. Description of outcomes of experimental infection with feline haemoplasmas: copy numbers, haematology, Coombs' testing and blood glucose concentrations. Vet Microbiol 139, 323-332.

Thrusfield, M.V., 1986. Veterinary epidemiology. Butterworths, London ; Boston, viii, 280 p. pp.

Vieira, R.F., Molento, M.B., dos Santos, L.C., Moraes, W., Cubas, Z.S., Santos, A.P., Guimaraes, A.M., Mohamed, A., Barros Filho, I.R., Biondo, A.W., Messick, J.B., 2009. Detection of a novel hemoplasma based on 16S rRNA gene DNA in captive and free-ranging capybaras (Hydrochaeris hydrochaeris). Vet Microbiol 139, 410-413.

Wengi, N., Willi, B., Boretti, F.S., Cattori, V., Riond, B., Meli, M.L., Reusch, C.E., Lutz, H., Hofmann-Lehmann, R., 2008. Real-time PCR-based prevalence study, infection follow-up and molecular characterization of canine hemotropic mycoplasmas. Vet Microbiol 126, 132-141.

Willi, B., Boretti, F.S., Baumgartner, C., Tasker, S., Wenger, B., Cattori, V., Meli, M.L., Reusch, C.E., Lutz, H., Hofmann-Lehmann, R., 2006a. Prevalence, risk factor analysis, and follow-up of infections caused by three feline hemoplasma species in cats in Switzerland. J Clin Microbiol 44, 961-969.

Willi, B., Boretti, F.S., Cattori, V., Tasker, S., Meli, M.L., Reusch, C., Lutz, H., Hofmann-Lehmann, R., 2005. Identification, molecular characterization, and experimental transmission of a new hemoplasma isolate from a cat with hemolytic anemia in Switzerland. J Clin Microbiol 43, 2581-2585.

Willi, B., Filoni, C., Catão-Dias, J.L., Cattori, V., Meli, M.L., Vargas, A., Martínez, F., Roelke, M.E., Ryser-Degiorgis, M.P., Leutenegger, C.M., 
Lutz, H., Hofmann-Lehmann, R., 2007. Worldwide occurrence of feline hemoplasma infections in wild felid species. J Clin Microbiol 45, 11591166.

Willi, B., Tasker, S., Boretti, F.S., Doherr, M.G., Cattori, V., Meli, M.L., Lobetti, R.G., Malik, R., Reusch, C.E., Lutz, H., Hofmann-Lehmann, R., $2006 \mathrm{~b}$. Phylogenetic analysis of "Candidatus Mycoplasma turicensis" isolates from pet cats in the United Kingdom, Australia, and South Africa, with analysis of risk factors for infection. J Clin Microbiol 44, 4430-4435. 
Tabela 1.1. Sequencias dos oligonucleotídeos desenhados para a PCR convencional espécie específica para o sequenciamento do gene $16 \mathrm{~S}$ rRNA de hemoplasmas de gatos infectados por múltiplas espécies

\begin{tabular}{|c|c|c|c|}
\hline $\begin{array}{l}\text { Nome do } \\
\text { primer }\end{array}$ & Sequencia do primer & $\mathrm{T}\left({ }^{\circ} \mathrm{C}\right)^{\mathrm{b}}$ & $\begin{array}{l}\text { Tamanho do } \\
\text { produto (pb) }\end{array}$ \\
\hline MhfFw1 & GCTGATGGTATGCCTAATACATGC & \multirow{2}{*}{59} & \multirow{2}{*}{1336} \\
\hline MhfRev1 & GCCСАСТССТСТСАTAGTTTGA & & \\
\hline $\mathrm{MhfFw}^{\mathrm{a}}$ & CGAACGGACTTTGGTTTCGG & \multirow{2}{*}{59} & \multirow{2}{*}{1214} \\
\hline MhfRev2 $^{\mathrm{a}}$ & CTTCAAGGAGGCGAATTGCAG & & \\
\hline CMhmFw1 & TACTCTCTTAGTGGCGAACGG & \multirow{2}{*}{60} & \multirow{2}{*}{1314} \\
\hline CMhmRev1 & CTCCCATAGTTTGACGGGCG & & \\
\hline $\mathrm{CMhmFw}^{\mathrm{a}}$ & AGGGTTTACTCTCTTAGTGGCG & \multirow{2}{*}{59} & \multirow{2}{*}{1375} \\
\hline $\mathrm{CMhmRev2}^{\mathrm{a}}$ & TCCAGTCAAAATTACCAATCTAGACG & & \\
\hline CMtFw1 & CTGTCCAAAAGGCAGTTAGCG & \multirow{2}{*}{59} & \multirow{2}{*}{1312} \\
\hline CMtRev1 & TGTGTTTTCAAATGCCCCTTCC & & \\
\hline $\mathrm{CMtFw}^{\mathrm{a}}$ & GTCCTATAGTATCCTCCATCAGACAG & \multirow{2}{*}{59} & \multirow{2}{*}{1039} \\
\hline CMtRev2 ${ }^{\mathrm{a}}$ & CGACACATTGTACTCACCATTGTAA & & \\
\hline Internal & GGGATTAGATACCCCAGTAGTCCAC & \multirow{4}{*}{59} & \multirow{4}{*}{600} \\
\hline forward & & & \\
\hline Internal & GTGGACTACTGGGGTATCTAATCCC & & \\
\hline reverse & & & \\
\hline
\end{tabular}

\footnotetext{
${ }^{a}$ Oligonucleotídeos externos selecionados para sequenciamento

${ }^{\mathrm{b}}$ Temperatura de anelamento
} 
Tabela 1.2. Número e porcentagem de gatos com resultados positivos na PCR para espécies de hemoplasmas no método convencional e em tempo real (quantitativo)

\begin{tabular}{lll}
\hline $\begin{array}{l}\text { Teste PCR / espécie de } \\
\text { hemoplasma encontrada }\end{array}$ & Número de amostras & Intervalo de \\
\hline PCR convencional gênero & $\mathbf{8 0 / 4 5 1}(\mathbf{1 7 . 7} \%)$ & $\mathbf{1 4 . 2 - 2 1 . 3 \%}$ \\
hemoplasmas & & \\
qPCR espécie específica & $\mathbf{6 0 / 4 3 2}(\mathbf{1 3 . 8 \% )}$ & $\mathbf{1 0 . 2 - 1 6 . 4 \%}$ \\
para hemoplasmas & & \\
Mhf & $48 / 432(11.1 \%)^{\mathrm{a}}$ & $7.8-13.5 \%$ \\
CMhm & $60 / 432(13.8 \%)^{\mathrm{a}}$ & $10.2-16.4 \%$ \\
CMt & $19 / 432(4.4 \%)^{\mathrm{b}}$ & $2.4-6.1 \%$ \\
Mhf apenas & 0 & 0 \\
CMhm apenas & $10 / 432(2.3 \%)$ & $0.9-3.6 \%$ \\
CMt apenas & 0 & 0 \\
Mhf e CMhm & $31 / 432(7.1 \%)$ & $4.5-9.2 \%$ \\
CMhm e CMt & $2 / 432(0.4 \%)$ & $-0.02-1.1 \%$ \\
Mhf e CMt & 0 & 0 \\
Mhf e CMhm e CMt & $17 / 432(3.9 \%)$ & $2-5.5 \%$ \\
\hline MyCOplasma haemofelis & &
\end{tabular}

$\mathrm{Mhf}=\overline{\text { Mycoplasma haemofelis }}$

CMhm = "Candidatus Mycoplasma haemominutum"

$\mathrm{CMt}=$ "Candidatus Mycoplasma turicensis"

${ }^{a}=$ sem diferença significativa $(p=0.2)$ presente entre os grupos marcados por essa letra

$\stackrel{b}{b}$ diferença significativa $(p=0.0002)$ presente neste grupo e outros com letras diferentes 
Tabela 1.3. Estatística descritiva (mediana e variação) e resultados do teste Kruskal-Wallis (valor $p$ ) para as variáveis hematológicas nos gatos agrupados de acordo com o resultado da qPCR espécie específica

\begin{tabular}{|c|c|c|c|c|c|c|}
\hline Variável & $\begin{array}{l}\text { Gatos } \\
\text { negativos } \\
(n=372)\end{array}$ & $\begin{array}{l}\text { CMhm } \\
\text { apenas } \\
(n=10)\end{array}$ & $\begin{array}{l}\text { Mhf e CMhm } \\
(n=31)\end{array}$ & $\begin{array}{l}\text { CMhm e CMt } \\
(n=2)^{a}\end{array}$ & $\begin{array}{l}\text { Mhf e CMhm } \\
\text { e CMt }(n=17)\end{array}$ & Valor $p$ \\
\hline VG (\%) & $31(4-53)$ & $31(21-38)$ & $29.5(8-44)$ & $30(27-34)$ & $27(12-34)$ & 0.11 \\
\hline $\begin{array}{l}\text { Número de } \\
\text { eritrócitos } \\
\left(\times 10^{6} / \mu \mathrm{L}\right)\end{array}$ & $8(0.9-16)$ & $9(4.4-10.6)$ & $7.5(1.2-12.5)$ & $8.9(7-10.7)$ & $8.1(3-9.8)$ & 0.25 \\
\hline $\begin{array}{l}\text { Concentração de } \\
\text { hemoglobina } \\
(\mathrm{g} / \mathrm{dL})\end{array}$ & $\begin{array}{l}11.5(1.5- \\
19.4)\end{array}$ & $\begin{array}{l}11.2(7.8- \\
14.9)\end{array}$ & $\begin{array}{l}11.5(2.6- \\
17.2)\end{array}$ & $11(10.3-11.8)$ & $\begin{array}{l}10.9(3.9- \\
15.6)\end{array}$ & 0.73 \\
\hline VCM (fl) & $38(16-110)$ & $\begin{array}{l}37.4(30.5- \\
47.4)\end{array}$ & $\begin{array}{l}38.4(29.4- \\
66.1)\end{array}$ & $\begin{array}{l}34.8(31.5- \\
38.2)\end{array}$ & $\begin{array}{l}37.9(27.6- \\
66.9)\end{array}$ & 0.5 \\
\hline $\mathrm{CHCM}(\%)$ & $\begin{array}{l}36.7(12.6- \\
71.6)\end{array}$ & $36.8(30-51.3)$ & $36.2(28-55.4)$ & $\begin{array}{l}36.4(34.7- \\
38.1)\end{array}$ & $\begin{array}{l}38(28.8-51- \\
8)\end{array}$ & 0.74 \\
\hline
\end{tabular}

Os valores indicam mediana e variação

${ }^{a}$ Grupo não incluído na avaliação estatística devido ao pequeno número de gatos

$\mathrm{VG}=$ volume globular

$\mathrm{VCM}=$ volume corpuscular médio

$\mathrm{CHCM}=$ concentração de hemoglobina corpuscular média

$\mathrm{CMhm}=$ "Candidatus Mycoplasma haemominutum"

Mhf = Mycoplasma haemofelis

$\mathrm{CMt}=$ "Candidatus Mycoplasma turicensis" 
Figura 1.1. Número relativo de cópias de DNA de hemoplasma/ $\mu$ de sangue para cada espécie de hemoplasma das amostras com resultados positivos na qPCR. Boxplots representando os quartis de 25th, 50th (mediana) e 75th com whiskers representando os maiores e menores valores. $\mathrm{Mhf}=$ gatos positivos na qPCR para Mycoplasma haemofelis, $\mathrm{CMhm}$ = gatos positivos na qPCR para "Candidatus Mycoplasma haemominutum", $\mathrm{CMt}=$ gatos positivos na qPCR para "Candidatus Mycoplasma turicensis"

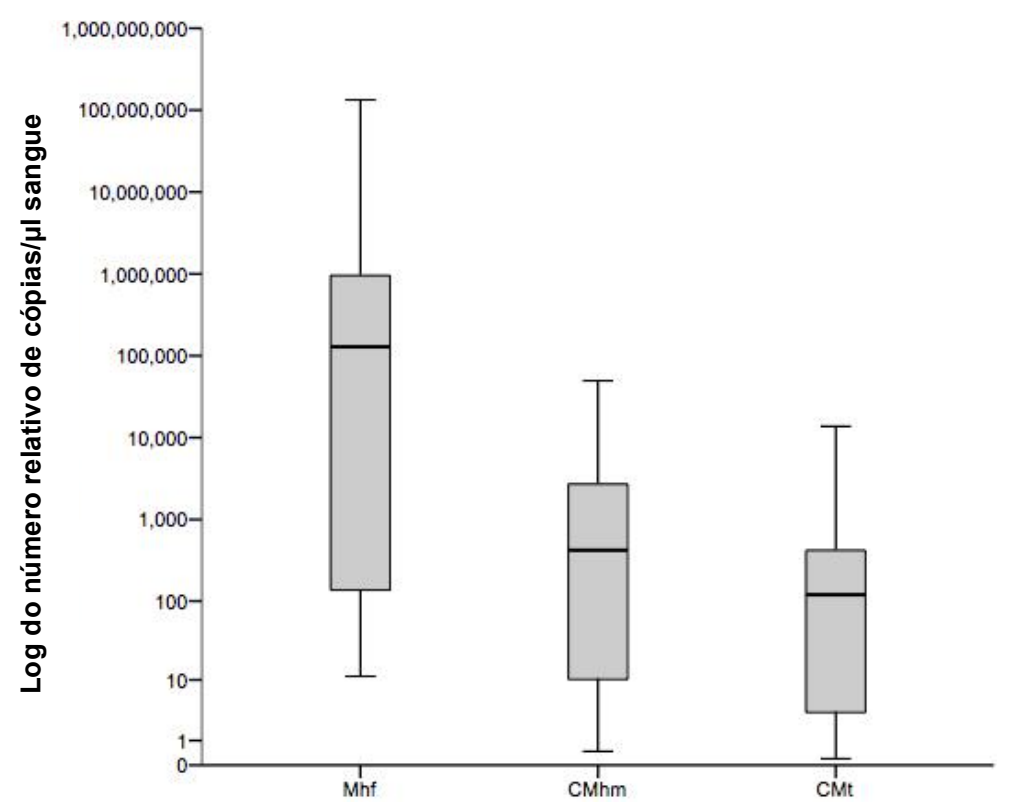


Figura 1.2. Diagrama representando o número de gatos positivos nas qPCRs espécie específicas incluindo a quantidade de gatos com infecções por duas e três espécies de hemoplasmas. Mhf = gatos positivos na GPCR para Mycoplasma haemofelis, $\mathrm{CMhm}$ = gatos positivos na qPCR para "Candidatus Mycoplasma haemominutum", CMt = gatos positivos na qPCR para "Candidatus Mycoplasma turicensis"

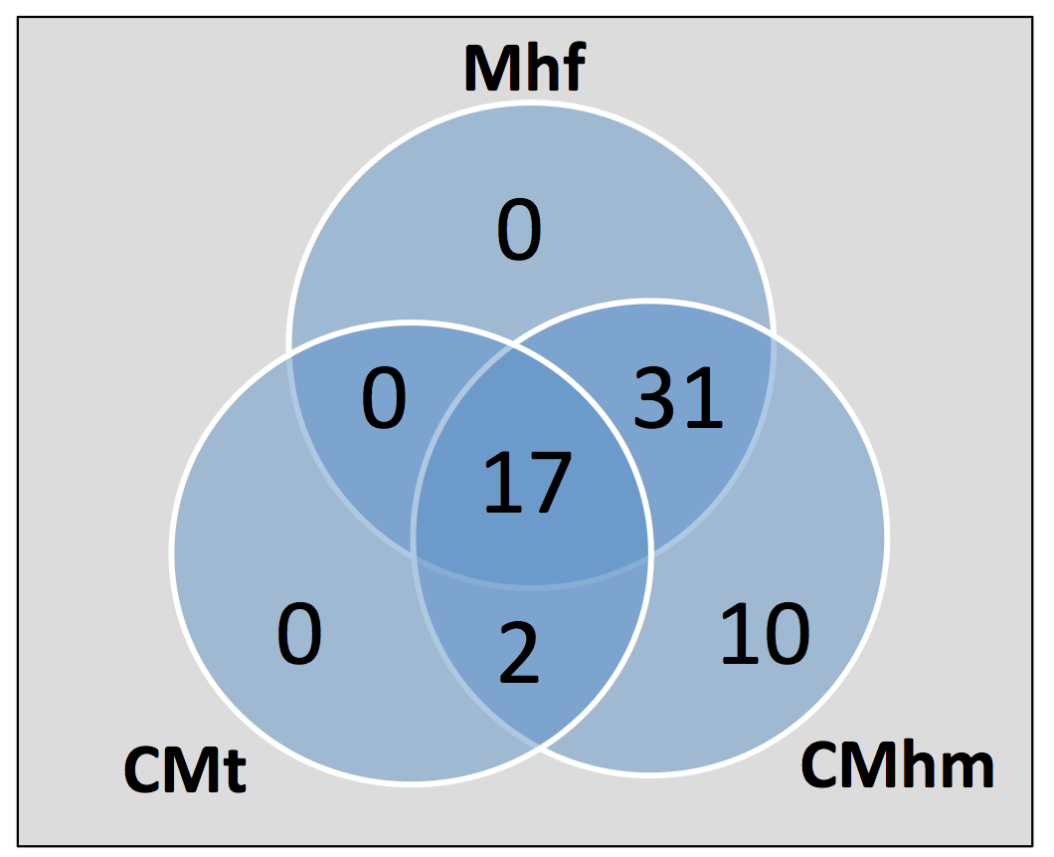


Figura 1.3. Análise filogenética das sequencias do gene $16 \mathrm{~S}$ rRNA das espécies Mhf, CMhm e CMt de gatos de Brasília e cidades satélites. $\mathrm{O}$ método de Neighbor-Joining foi usado para construir a árvore filogenética, cujos valores de bootstrap nos nodos (apenas valores $\geq 700$ são mostrados). As distâncias evolucionárias estão na escala. Clostridium spp. foi usado como grupo externo. Os números de acesso no GenBank estão indicados na figura. As sequencias de Mhf (B6, B7, C6, D4, E7, F2, F3, F5, G4, H2), CMhm (A8, B4, B5, B8, D1, D2, D4, D5, E3, H4) e CMt (B1, B2, D4, E7, F3, F4, F5, G1, $\mathrm{G} 4, \mathrm{G} 5, \mathrm{H} 4$ ) foram geradas no presente estudo. Mhf= Mycoplasma haemofelis, $\mathrm{CMhm}=$ "Candidatus Mycoplasma haemominutum", CMt= "Candidatus Mycoplasma turicensis". 


\section{CAPÍTULO 2}

\section{ARTIGO 2. ANÁLISE DOS FATORES DE RISCO E OCORRÊNCIA DAS INFECÇÕES POR HEMOPLASMAS EM CÃES}

L. C. Aquino ${ }^{a^{*}}$, J. Kamani ${ }^{d}$, A. M. Haruna ${ }^{\mathrm{e}}$, G. R. Paludo ${ }^{\mathrm{a}}$, C. A. Hicks ${ }^{\mathrm{b}}$, C. R. Helps $^{\mathrm{b}, \mathrm{c}}$, S. Tasker ${ }^{\mathrm{b}, \mathrm{c}}$

aLaboratorio de Patologia Clinica Veterinária, Faculdade de Agronomia e Medicina Veterinária, Universidade de Brasília, Campus Universitário Darcy Ribeiro, Brasília, Brasil, 709010-900

${ }^{b}$ School of Veterinary Sciences, University of Bristol, Langford House, Langford, Bristol BS40 5DU, UK

${ }^{\mathrm{C}}$ Molecular Diagnostic Unit, Langford Veterinary Services, Langford, Bristol, BS40 5DU

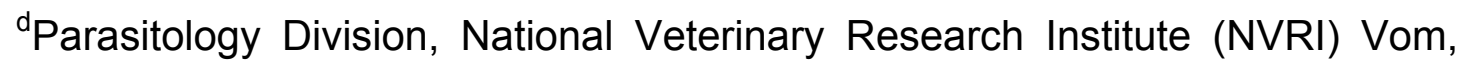
Plateau state, Nigeria

${ }^{\text {e}}$ State Veterinary Hospital Jos, Ministry of Agriculture and Natural Resources, Plateau State, Nigeria

Autor para correspondência*

E-mail: larissaquino@gmail.com

Submetido para publicação na Veterinary Parasitology (comprovante em ANEXO B) 


\subsection{Abstract}

Mycoplasma haemocanis (Mhc) and 'Candidatus Mycoplasma haematoparvum' (CMhp) are canine haemoplasma species that can induce anaemia in immunocompromised and/or splenectomised dogs. This study aimed to determine the occurrence and phylogeny of canine haemoplasma species in dogs from Nigeria and describe any risk factors for infection. Canine haemoplasma species-specific and generic haemoplasma qPCR assays were used. The species-specific QPCR assays found Mhc infection in 18 of 245 dogs $(7.3 \%)$, and CMhp infection in only one dog $(0.4 \%)$. The generic haemoplasma qPCR assays were positive in 44 of $245(17.9 \%)$ dogs. Twenty-five dogs had discordant QPCR results in that they were generic haemoplasma GPCR positive but species-specific QPCR negative. Further evaluation of these dogs by $16 \mathrm{~S}$ rDNA sequencing gave limited results but 5 were confirmed to be infected with non-haemoplasma species: The 16S rRNA gene sequences from Mhc species showed $>99.8 \%$ identity with each other and $>99.6 \%$ identity with GenBank sequences, and resided in a single clade with other global Mhc and Mycoplasma haemofelis sequences, indicating low $16 S$ rRNA genetic variability amongst this canine haemoplasma species.

Keywords: haemoplasmas, Nigeria, dogs, prevalence, risk factors 


\section{Resumo}

Mycoplasma haemocanis (Mhc) e 'Candidatus Mycoplasma haematoparvum' (CMhp) são espécies de hemoplasmas caninos que induzem anemia em cães imunossuprimidos e/ou esplenectomizados. Este estudo teve como objetivo avaliar a ocorrência e filogenia das espécies de hemoplasmas em cães da Nigéria e descrever fatores de risco envolvidos com a infecção. Foram utilizados qPCR espécies específicas e de gênero de hemoplasmas. A qPCR espécie específica detectou infecção por Mhc em 18 dos 245 cães $(7,3 \%)$ e CMhp em apenas um cão $(0,4 \%)$. A qPCR de gênero de hemoplasmas foi positiva em 44 dos 245 (17,9\%) dos cães. Vinte e cinco cães tiveram resultados discordantes nas qPCRs, nos quais foram positivos na qPCR de gênero de hemoplasmas, mas negativos na qPCR espécie específica. A avaliação desses cães discordantes por meio do sequenciamento do gene 16S rRNA gerou resultados limitados, mas em 5 cães confirmou-se a infecção por espécies diferentes de hemoplasmas: 2 Anaplasma phagocytophilum, 1 Anaplasma ovis, 1 Serratia marcescens e 1 Aerococcus spp. O sequenciamento do gene 16S rRNA dos Mhc mostrou $>99,8 \%$ de identidade entre elas e $>99,6 \%$ de identidade com sequencias disponíveis no GenBank e permaneceram no mesmo grupo de outras sequencias de Mhc e Mycoplasma haemofelis, indicando baixa variabilidade genética do gene $16 \mathrm{~S}$ rRNA entre Mhc de diferentes origens.

Palavras-chave: hemoplasmas, Nigeria, cães, prevalência, fatores de risco 


\subsection{INTRODUÇÃO}

Hemoplasmas são pequenos micoplasmas hemotrópicos que parasitam a superfície de eritrócitos de uma ampla variedade de mamíferos (Messick, 2004). Cães são infectados principalmente pelas espécies Mycoplasma haemocanis (Mhc) e 'Candidatus Mycoplasma haematoparvum' (CMhp). As infecções são geralmente crônicas e subclínicas em cães imunocompetentes, mas podem causar sinais clínicos relacionados a anemia hemolítica após esplenectomia, imunossupressão ou infecções concorrentes (Messick et al., 2002; Sykes et al., 2005).

Ambas espécies, Mhc e CMhp, já foram descritas na Espanha (Novacco et al., 2010; Roura et al., 2010), Trinidade (Barker et al., 2010), França (Kenny et al., 2004), Suíça (Wengi et al., 2008), Portugal (Novacco et al., 2010), Itália (Novacco et al., 2010), Japão (Sasaki et al., 2008), Estados Unidos (Compton et al., 2012), Grécia (Tennant et al., 2011) e Austrália (Barker et al., 2012; Hetzel et al., 2012). Estudos prévios (Kenny et al., 2004; Novacco et al., 2010) reportaram que cães que vivem em climas quentes tropicais e subtropicais têm maior risco de infecção por hemoplasmas devido a presença de ectoparasitas, tais como Rhipicephalus sanguineus, que já foi proposto como vetor para hemoplasmas (Kenny et al., 2004). Porém, ainda não há estudos confirmando a transmissão de hemoplasmas caninos por vetores e ainda há pouca informação sobre os fatores de risco para hemoplasmas caninos em países de clima quente, como África e América do Sul. 
Um estudo descreveu a presença de patógenos tais como Hepatozoon canis, Ehrlichia canis, Rickettsia spp., Babesia rossi e Anaplasma platys em dois gêneros de carrapatos, Rhipicephalus and Heamaphysalis, em cães da Nigéria, África (Kamani et al., 2013). Embora hemoplasmas já tenham sido descritos em cães da África, na Tanzânia (Barker et al., 2010) e Sudão (Inokuma et al., 2006), nenhum estudo avaliou a prevalência de hemoplasmas na Nigéria (Kamani et al., 2013).

O objetivo deste estudo foi investigar as correlações entre a infecção por hemoplasmas e os potenciais fatores de risco em cães, além de avaliar a ocorrência de hemoplasmas em cães da Nigéria por meio da qPCR e caracterizar por ferramentas moleculares o gene 16S rRNA das espécies identificadas. 


\subsection{MATERIAL E MÉTODOS}

\section{Seleção e coleta das amostras}

Utilizou-se uma amostragem de conveniência por meio da qual obtevese o maior número de amostras de cães atendidos em clínicas veterinárias na cidade de Jos, Plateau State, Nigeria e de amostras submetidas ao Laboratório de Divisão de Parasitologia, Instituto Nacional de Pesquisa Veterinária, Vom, Nigéria. Amostras de $5 \mathrm{ml}$ de sangue de cães foram coletadas em tubos com EDTA. O volume globular (VG) foi determinado pelo método do microhematócrito e a anemia foi definida para cães com VG < $35 \%$. As amostras foram armazenadas a $4^{\circ} \mathrm{C}$ e enviadas para a Universidade de Bristol, Reino Unido para análise molecular. Dados referentes a idade, gênero (incluído se os animais eram castrados ou não), raça, se o animal era proveniente de casa ou abrigo, a condição clínica (saudável ou doente, baseado no histórico e exame clínico), presença de carrapatos, profilaxia contra ectoparasitas, histórico de esplenectomia e histórico de viagens foram descritos para cada cão.

\section{Extração de DNA}

Um QIAxtractor foi usado para extrair DNA de $100 \mu$ l de sangue com EDTA usando o kit de reagentes DX (Qiagen) de acordo com as recomendações do fabricante. O DNA foi eluido em $100 \mu l$ de tampão de eluição e armazenadas a $-20^{\circ} \mathrm{C}$ até análise. Dois controles negativos (tampão fosfato salino) foram extraídos em paralelo para cada 94 amostras. 


\section{qPCR espécie específico}

As amostras foram submetidas a qPCR específicas para Mhc e CMhp conforme previamente descrito por Barker et al. (2010). Cada ensaio foi combinado com uma qPCR para a deteç̧ão do gene GAPDH (desidrogenase gliceraldeído-3-fosfato) como controle interno para demonstrar a presença de DNA passível de amplificação e livre de inibidores da PCR. O número de ciclos $=26(\mathrm{Ct})$ foi estabelecido como limite acima do qual a extração da amostra deveria ser repetida assim como a qPCR. Para cada conjunto de 94 amostras o DNA de um cão hemoplasma positivo foi incluído como controle positivo e água foi usada como controle negativo.

\section{qPCR para o gênero hemoplasma}

As amostras também foram submetidas a qPCR para o gênero hemoplasma previamente descrita por Tasker et al. (2010) desenhada para detectar novas espécies de hemoplasmas. Essa qPCR é constituída por duas reações separadas que amplificam sequencias do gene $16 \mathrm{~S}$ rRNA dos dois principais grupos de espécies de hemoplasmas: o grupo hemominutum (HM) e o grupo hemofelis (HF). Essas duas reações podem detectar qualquer espécie de hemoplasma que não tenha sido detectada nos ensaios específicos para Mhc ou CMhp por diferenças nos locais de ligação dos oligonucleotídeo ou probe. O protocolo adaptado consistiu de $12.5 \mu \mathrm{L}$ de $2 \mathrm{X}$ Promega GoTaq Hot Start Colorless Master Mix (UK) com $0.2 \mu \mathrm{M}$ de cada oligonucleotídeo, $0.1 \mu \mathrm{M}$ de probe, concentração final de $4.5 \mathrm{mM}$ de $\mathrm{MgCl}_{2}$ e $5 \mu$ l de DNA da amostra e água para completar $25 \mu \mathrm{L}$. Todas as reações foram realizadas no termociclador Agilent MX3005P (Agilent, UK) com incubação 
inicial de $95^{\circ} \mathrm{C}$ por 2 minutos seguido de 45 ciclos de $95^{\circ} \mathrm{C}$ por 10 segundos e $60^{\circ} \mathrm{C}$ por 30 segundos durante o qual a fluorescência foi registrada. Em cada conjunto de 94 amostras, DNA de um cão positivo para hemoplasma foi utilizado como controle positivo e água como controle negativo.

\section{PCR convencional e sequenciamento do gene 16S rRNA}

Todos os cães com resultados discordantes (positivos na qPCR para gênero de hemoplasma e negativo na QPCR espécie específica) foram submetidos a duas PCR convencionais diferentes para ampliar a maior extensão do gene 16S rRNA possível e realizar o sequenciamento. A primeira PCR convencional amplificou $\cong 1400 \mathrm{bp}$ do gene $16 \mathrm{~S}$ rRNA e utilizou oligonucleotídeos universais (8F e 1492R) previamente descritos por Pitulle e

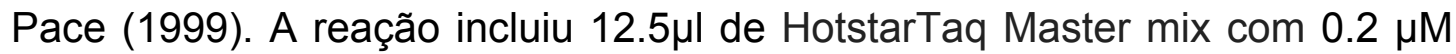
de cada primer, $3.0 \mathrm{mM}$ de $\mathrm{MgCl}_{2}$ e $5 \mu \mathrm{l}$ da amostra de DNA com água para completar $25 \mu \mathrm{L}$. A reação foi realizada em um termociclador (SureCycler 8800 - Agilent Technologies, USA) nas seguintes condições: $95^{\circ} \mathrm{C}$ por 15 minutes seguido de 45 ciclos de $95^{\circ} \mathrm{C}$ por 15 segundos, $48^{\circ} \mathrm{C}$ por 30 segundos, $72^{\circ} \mathrm{C}$ por 2 minutos, e extensão final de $72^{\circ} \mathrm{C}$ por 10 minutos. $\mathrm{A}$ segunda PCR convencional amplificou $\cong 1100 \mathrm{bp}$ do gene $16 \mathrm{~S}$ rRNA das espécies Mycoplasma haemofelis (Mhf)/Mhc e 'Candidatus Mycoplasma haemominutum' (CMhm)/CMhp usando oligonucleotídeos espécie específicos (MhfFw2 e MhfRev2; CMhmFw2 e CMhmRev2, respectivamente) previamente descritos (Aquino et al., 2014). Esta reação consistia em $12.5 \mu \mathrm{L}$ de 2X Promega GoTaq® Hot Start Colorless Master Mix (UK) com $0.2 \mu \mathrm{M}$ de cada primer e $1 \mu \mathrm{L}$ de DNA da amostra e água para completar o volume final 
de $25 \mu \mathrm{L}$. A reação ocorreu em um termociclador (SureCycler 8800 - Agilent Technologies, USA) nas seguintes condições: $95^{\circ} \mathrm{C}$ por 5 minutos, seguido por 45 ciclos de amplificação $\left(95^{\circ} \mathrm{C}, 10\right.$ segundos; $62^{\circ} \mathrm{C}, 30$ segundos; $72^{\circ} \mathrm{C}$, 90 segundos) com extensão final de $72^{\circ} \mathrm{C}$ por 5 minutos. Amostras sabidamente Mhc e Mhf positivas foram usadas como controles positivos para os oligonucleotídeos MhfFw2 e MhfRev2, e amostras sabidamente positivas para CMhp e CMhm foram usadas como controles positivos para os oligonucleotídeos CMhmFw2 e CMhmRev2. Água foi usada como controle negativo em cada teste de PCR. Os produtos da PCR foram identificados por eletroforese em gel de agarose a 1,5\% corado com brometo de etídio. Amostras que apresentaram múltiplas bandas fracas foram reamplificadas nas mesmas condições, mas com número de ciclos reduzidos para 20 e usando $<1 \mu$ do produto da PCR anterior como amostra.

Os produtos da PCR dos tamanhos esperados foram purificados com NucleoSpin ${ }^{\circ}$ Gel e PCR Clean-up kit (MACHEREY NAGEL GmbH \& Co.) de acordo com as recomendações do fabricante, quantificados no fluorômetro Qubit $^{\mathrm{TM}}$ (Invitrogen ${ }^{\mathrm{TM}}$ ) e submetidos ao serviço de sequenciamento de DNA MRC PPU, College of Life Sciences, University of Dundee, Scotland, (www.dnaseq.co.uk) para sequenciamento usando o Big-Dye Ver 3.1 Applied Biosystems em um sequenciador de DNA capilar automático modelo 3730 Applied Biosystems.

Edição e análise das sequencias foram realizadas no programa MacVector versão 13.0.3, Inc. A reconstrução das sequências quase completas do gene 16S rRNA foi feita a partir dos produtos da primeira ou da segunda PCR convencional da seguinte forma: as sequencias derivadas dos 
oligonucleotídeos 8F e 1492R foram combinadas com sequencias geradas pelos oligonucleotídeos internos (HBT-F e HBT-R) previamente descritas por Criado-Fornelio et al. (2003). As sequencias derivadas dos oligonucleotídeos MhfFw2 e MhfRev2 foram combinadas com sequencias geradas pelos oligonucleotídeos internos previamente descritos por Aquino et al. (2014). Essas novas sequencias do gene 16S rRNA foram inicialmente comparadas com sequencias disponíveis no GenBank usando a ferramenta BLAST e em seguida foram alinhadas com sequencias do gene 16S rRNA de hemoplasmas caninos disponíveis no GenBank usando o Clustal-W para determinar a proximidade filogenética.

As sequencias do gene $16 \mathrm{~S}$ rRNA de 4 dos 17 Mhc detectados neste estudo foram submetidas ao GenBank com os seguintes números de acesso: KP715857, KP715858, KP715859 e KP715860. Essas sequencias foram usadas para construir a árvore filogenética a partir das distâncias das matrizes usando o método de Neighbour-Joining. Os dados foram reamostrados 1000 vezes para gerar os valores de bootstrap.

\section{Análise estatística}

Os dados foram computados no Excel® e a avaliação estatística foi realizada no programa SPSS para Windows (SPSS Inc., Chicago IL, USA). Os resultados das qPCRs (gênero de hemoplasma, Mhc e CMhp) foram testados para associação com variáveis categóricas (gênero, raça, animais de casas $\mathrm{x}$ animais de abrigos, condição clinica, presença de ectoparasitas e profilaxia para ectoparasitas) usando o teste $x^{2}$. A comparação estatística entre as prevalências de Mhc e CMhp foi realizada usando o teste $x^{2}$. O teste 
Kolmogorov-Smirnov foi usado para testar se a distribuição das variáveis contínuas (VG e idade) seguia distribuição normal. O teste Mann-Whitney U foi usado para determinar se havia diferença significante entre os resultados das qPCRs (genérica, Mhc e CMhp) e VG e idade. O valor $p<0.05$ foi considerado significante. 


\subsection{RESULTADOS}

Um total de 246 amostras foram coletadas por conveniência no presente estudo, cujos dados estão resumidos na tabela 2.1. Dados sobre a idade estavam disponíveis para 245 cães e variou de 2 a 9 anos (mediana: 2 anos). Nenhum dos cães do estudo era castrados, exceto dois cães machos castrados com idade de 1 e 1,5 anos. Dois cães tinham histórico de viagens para fora da Nigéria (um macho de 4 anos e uma fêmea de 5 anos). Nenhum animal incluído neste estudo sofreu esplenectomia. Devido ao pequeno número de animais castrados, com histórico de esplenectomia e com histórico de viagens, essas variáveis foram excluídas da análise estatística. Dados referentes ao VG estavam disponíveis para 228 cães e variou de 10 a 62\% (mediana: 42\%). Dos 246 cães avaliados para a presença de carrapatos, $135(55,1 \%)$ estavam infectados por carrapatos, todos da espécie Rhipicephalus sanguineus.

239 amostras foram positivas na qPCR para GAPDH (Ct $\leq 26)$ (mediana Ct: 15, variação 12-26) e portanto foram consideradas adequadas para futuras reações moleculares. Seis cães não apresentaram valores de Ct na qPCR para GAPDH e tiveram que ser re-extraídos. Após a re-extração, cinco essas amostras apresentaram valores de Ct $\leq 26$ (variação 12-19), mas uma amostra apresentou $\mathrm{Ct=34}$ na qPCR GAPDH após a re-extração e por isso foi excluída do estudo. Portanto, 245 cães constituíram a população final desse estudo. Todos os controles positivos e negativos para extração de DNA e qPCRs geraram resultados positivos e negativos, respectivamente. 
A qPCR espécie específica detectou 7,3\% (18/245) cães positivos para Mhc (mediana $\mathrm{Ct}=27$, variação=19-44) e um cão positivo para CMhp $(0,4 \%)(\mathrm{Ct}=43)$. A frequência de Mhc foi significativamente maior do que a frequência de CMhp $(p=0,03)$. Nenhum cão apresentou infecção concomitante por Mhc e CMhp.

A qPCR de gênero para o grupo HF foi positiva individualmente (resultados negativos na reação para o grupo HM) em 27 cães (mediana $\mathrm{Ct}=37$, variação=30-44). Já a reação para o grupo $\mathrm{HM}$ foi positiva individualmente (resultados negativos na reação para o grupo HF) em dois cães (Cts de 24 e 39). As reações para o grupo HM e HF foram ambas positivas em 13 cães (mediana $\mathrm{Ct} \mathrm{HF}=23$, variância=15-31; mediana $\mathrm{Ct} \mathrm{HM=}$ 26, variância=13-40). Onze desses 13 animais tiveram Cts menores para HF em relação ao $\mathrm{HM}$, indicando estarem infectados por espécies de hemoplasmas pertencentes ao grupo hemofelis como previamente descrito (Tasker et al., 2010), enquanto dois cães apresentaram Cts para HM menores em comparação ao HF, o que indica infecção por espécies de hemoplasmas do grupo hemominutum (Tasker et al., 2010). A qPCR para gênero de hemoplasma foi considerada positiva em qualquer cão com resultado positivo na reação $\mathrm{HF}$ e/ou na reação $\mathrm{HM}$, dessa forma $17,1 \%$ (42/245) dos cães foram positivos para hemoplasmas na qPCR para gênero de haemoplasma (tabela 2.2).

Não houve associação significativa entre resultado positivo na qPCR para gênero de hemoplasma ou na GPCR para Mhc e qualquer uma das variáveis analisadas, incluído VG. Nem houve correlação entre resultado de qualquer uma das qPCRs e a presença de anemia (tabela 2.1). 
Vinte e três cães apresentaram resultados discordantes entre a qPCR para gênero de hemoplasma e a qPCR espécie específica. Duas PCRs convencionais foram usadas para ampliar e sequenciar o gene 16S rRNA dos hemoplasmas desses cães, mas apenas nove geraram produtos visíveis nas PCRs convencionais e seguiram para o sequenciamento. Cinco dessas nove amostras geraram produtos com os oligonucleotídeos $8 \mathrm{~F}$ e $1492 \mathrm{R}$ e as outras quatro amostras geraram produtos com os oligonucleotídeo MhfFw2 e MhfRev2. Os outros 14 cães discordantes não geraram produtos visíveis nas PCRs convencionais, o que era esperado considerando o alto valor do $\mathrm{Ct}$ (mediana=39, variância=33-44) observado nessas amostras na qPCR para gênero de hemoplasma.

Das cinco sequencias do gene 16S rRNA geradas a partir dos oligonucleotídeos 8F e 1492R, duas foram 100\% idênticas ao Anaplasma phagocytophilum (KP745629), uma sequencia foi 99\% idêntica ao Anaplasma ovis (KJ410246), uma sequencia foi $100 \%$ idêntica a Serratia marcescens (KR133281) e uma sequencia foi $100 \%$ idêntica ao Aerococcus spp. (KP943730). As quatro sequencias geradas a partir dos oligonucleotídeos MhfFw2 e MhfRev2 apresentaram $>99,5 \%$ de identidade com sequencias de Mhc e Mhf de estudos de diferentes países. A árvore filogenética das sequencias do Mhc deste estudo não revelou qualquer agrupamento por região ou hospedeiro. As quatro sequencias de Mhc geradas neste estudo ficaram em um único grupo com outras sequencias de Mhc e Mhf de outros países (figura 2.1). 


\subsection{DISCUSSÃO}

Este estudo reportou pela primeira vez a ocorrência de espécies de hemoplasmas em cães na Nigéria (tabela 2.2). A ocorrência geral foi similar àquela encontrada no sul da França (Kenny et al., 2004), Espanha (Roura et al., 2010) e Tanzânia (Barker et al., 2010), superior as prevalências encontradas na Suíça (Wengi et al., 2008), Grécia (Tennant et al., 2011), Trinidade (Barker et al., 2010), Itália (Novacco et al., 2010) e Reino Unido (Warman et al., 2010) e inferior as prevalências de Portugal (Novacco et al., 2010), Sudão (Inokuma et al., 2006) e Austrália (Barker et al., 2012). Em relação a ocorrência de Mhc, cães da Nigéria apresentaram ocorrência similar a de Trinidade (Barker et al., 2010) e Grécia (Tennant et al., 2011), superior a de cães na França (Kenny et al., 2004), Itália (Novacco et al., 2010), Suíça (Wengi et al., 2008), Reino Unido (Warman et al., 2010) e Espanha (Novacco et al., 2010). A ocorrência por CMhp encontrada foi a menor dentre os estudos de prevalência (Barker et al., 2010; Kenny et al., 2004; Novacco et al., 2010; Tennant et al., 2011; Warman et al., 2010), exceto na Suíça (Wengi et al., 2008) e Espanha (Roura et al., 2010). Estudos sobre hemoplasmas em cães conduzidos na França (Kenny et al., 2004) e Sudão (Inokuma et al., 2006) relataram prevalência de CMhp maior que Mhc, em contraste com os achados do presente estudo e de Trinidade (Barker et al., 2010), nos quais Mhc foi significativamente mais prevalente que CMhp $(p=0,03)$. Assim como estudos na Suíça (Wengi et al., 2008), Austrália (Hetzel et al., 2012), EUA (Compton et al., 2012) e Reino Unido (Warman et al., 2010), no presente estudo não foram encontrados cães infectados por 
mais de uma espécie de hemoplasma, o que contrasta com a maioria dos estudos sobre prevalência de hemoplasmas em cães (Barker et al., 2010; Kenny et al., 2004; Novacco et al., 2010; Roura et al., 2010; Tennant et al., 2011) os quais relataram cães co-infectados por Mhc e CMhp.

As diferenças entre as ocorrências de Mhc e CMhp encontradas neste estudo e outros já descritos podem ser reflexo da população de cães amostrada. O presente estudo incluiu principalmente cães domiciliados criados como animais de estimação e poucos cães de abrigo ou canis, o que pode ter contribuído para a baixa ocorrência de Mhf e CMhp. Um estudo realizado nos EUA (Kemming et al., 2004b) avaliando infecção por hemoplasmas nas populações de cães de estimação e cães de canis encontrou que cães de canis tinham maior risco de serem infectados por hemoplasmas, cuja prevalência foi de $35 \%$, superior a ocorrência descrita no presente estudo. Outro estudo da Austrália (Barker et al., 2012) amostrando apenas cães de rua encontrou prevalências de Mhc e CMhp maiores que em cães domiciliados, o que está de acordo com o encontrado no presente estudo, embora comparações diretas não podem ser feitas, pois o acesso dos cães a rua não foi registrado no presente estudo.

Um estudo realizado em cães de países do Mediterrâneo encontrou que não ter raça definida era um fator de risco para infecção por hemoplasmas, contudo nesse mesmo estudo a maioria dos cães sem raça definida viviam em canis, que também foi definido como um fator de risco para infecção por hemoplasmas (Novacco et al., 2010; Tennant et al., 2011), contudo, os autores acreditam que as condições de vida sejam mais importantes do que a raça como fator de risco para a infecção. Diferentes 
populações de cães apresentam atividades e comportamentos diversos que podem estar envolvidos em outras formas de transmissão de hemoplasmas, tais como inoculação direta ou infecção transplacentária (Compton et al., 2012).

Reações de PCR com vários graus de sensibilidade também podem contribuir para diferenças nas prevalências de hemoplasmas relatadas em cães (Compton et al., 2012). Pouca qualidade do DNA e/ou inibidores da PCR podem resultar em falsos negativos e consequentemente baixas prevalências, caso a PCR não inclua controles internos como o incluído no presente estudo.

O clima também pode exercer influência nas prevalências por estar associado com potenciais vetores, uma vez que cães de países de clima quente tais como Portugal (Novacco et al., 2010), Sudão (Inokuma et al., 2006), Tanzânia (Barker et al., 2010) e sul da França (Kenny et al., 2004) têm maior risco de infecção por hemoplasmas. No presente estudo, a ocorrência geral de hemoplasmas foi comparável àquela encontrada em regiões de climas similares, tais como sul da França (Kenny et al., 2004), Espanha (Roura et al., 2010) e Tanzânia (Barker et al., 2010). Esse achado combinado com a diferença próxima de significativa encontrada nas ocorrências de hemoplasmas entre cães com e sem carrapatos (tabela 2.1), indicam que carrapatos podem ser potenciais vetores para hemoplasmas.

Patógenos transmissíveis por carrapatos já foram identificados em cães e carrapatos da Nigéria (Ogo et al., 2012; Reye et al., 2012). No presente estudo, observou-se uma associação próxima da significativa entre profilaxia para ectoparasitas e infecção por hemoplasmas. Evidência de 
associação entre o carrapato Rhipicephalus sanguineus e infecção por hemoplasmas em cães foi descrita por Wengi et al. (2008), ao identificar cães residentes na Suíça infectados por hemoplasmas com histórico de terem viajado para países onde esse carrapato é encontrado. O estudo nos países do Mediterrâneo também documentou associação entre a exposição a carrapatos e infecção por hemoplamas em cães (Novacco et al., 2010). Porém, outro estudo (Barker et al., 2010) não encontrou qualquer associação similar. Contudo, deve-se considerar que hemoplasmas causam infecções crônicas e, portanto, uma exposição recente a carrapatos pode não estar aparente. Além disso, o modo de transmissão das hemoplasmoses caninas a campo ainda não foi esclarecido (Barker et al., 2010).

Não houve associação significativa entre infecção por hemoplasmas e idade, conforme anteriormente relatado (Barker et al., 2010; Kenny et al., 2004; Tennant et al., 2011; Wengi et al., 2008).

Um estudo prévio (Barker et al., 2010) encontrou que machos são mais propensos a infecção por Mhc do que fêmeas, o que está de acordo com os achados do presente estudo, uma vez que associação próxima a significativa $(p=0,06)$ foi encontrada para infecção por Mhc e gênero masculino.

Não foi encontrada associação significativa entre infecção por hemoplasmas e VG ou presença de anemia, o que de acordo com estudos prévios (Barker et al., 2010; Hetzel et al., 2012; Novacco et al., 2010; Roura et al., 2010) pode ter relação com infecção crônica ou a baixa patogenicidade dos hemoplasmas em cães (Compton et al., 2012), conforme o estudo feito por Wengi et al. (2008) que monitorou cães infectados por hemoplasmas e 
demonstrou que, apesar de resultados de PCR continuamente positivos, não observou-se anemia. Fatores adicionais, como imunossupressão e esplenectomia, são necessários para induzir doença clínica em cães infectados por hemoplasmas (Novacco et al., 2010; Warman et al., 2010). Tais fatores não foram apresentados por nenhum dos cães do presente estudo.

Vinte e três cães foram positivos na qPCR para gênero de hemoplasma mas negativos na qPCR espécie específica. As sequencias do gene 16S rRNA de quatro desses cães revelaram que eles eram idênticos ao Mycoplasma haemocanis. Essas amostras apresentaram baixo número de cópias de hemoplasmas (Cts $>30)$, o que pode ter sido a razão para o resultado discordante. Em cinco dos 23 cães discordantes, os resultados do sequenciamento do gene 16S rRNA mostrou semelhança com espécies de bactérias diferentes de hemoplasmas: dois cães estavam infectados por Anaplasma phagocytophilum, que, junto a Anaplasma platys é um dos agentes causadores da anaplasmose canina (Beall et al., 2008); um cão estava infectado por Anaplasma ovis, uma espécie reconhecida por infectar ovelhas (Giangaspero et al., 2015) mas que ainda não foi relatada em cães; um cão estava infectado por Serratia marcescens, um agente oportunista reconhecido por causar infecção nosocomial em cães (Lobetti et al., 2012; Perez et al., 2011) e um cão estava infectado com Aerococcus sp., recentemente observado em um cão causando infecção urinária (Budreckis et al., 2015). Esses achados indicam que a qPCR para gênero de hemoplasma pode detectar bactérias diferentes de hemoplasmas e ressalta a importância de sequenciar animais com resultados positivos em ensaios de 
PCR de gênero. Porém, é possível que esses animais discordantes também estivessem co-infectados por hemoplasmas, mas a PCR amplificou outras co-infecções (por exemplo Anaplasma sp.) presentes em maior concentração no sangue. Os autores acreditam que o uso de PCRs genéricas para hemoplasmas seja importante para avaliar possíveis infecções por novas espécies de hemoplasmas com sequencias diferentes que possam interferir no local de ligação do oligonucleotídeo e/ou probe das qPCRs espécies especificas. Tentativas adicionais de amplificar e sequenciar o gene $16 \mathrm{~S}$ rRNA dos 14 cães discordantes restantes falharam, portanto é possível que outras espécies de bactéria ou novas espécies de hemoplasmas estivessem presentes nessas amostras, conforme anteriormente relatado (Hii et al., 2012; Varanat et al., 2011), mas em níveis muitos baixos para serem amplificados pelas PCR convencionais.

As sequencias do gene $16 \mathrm{~S}$ rRNA do Mhc gerados no presente estudo não apresentaram variabilidade genética comparados a outras sequencias de Mhc de cães já publicadas de outros países (Novacco et al., 2010; Tasker et al., 2003) e se organizaram em um único grupo na análise filogenética (figura 2.1). A árvore filogenética demonstrou que as espécies de hemoplasmas caninos concentraram-se em dois grupos distintos: um grupo formado por CMhp e CMhm e o outro constituído por Mhc e Mhf, conforme anteriormente descrito (Tasker et al., 2003). As novas sequencias de hemoplasmas geradas no presente estudo apresentaram $>99,6 \%$ de identidade com sequencias anteriormente publicadas de Mhc e Mhf (Kenny et al., 2004; Messick et al., 2002). Um achado similar, no qual sequencias do $16 \mathrm{~S}$ rRNA de Mhc e Mhf compartilharam $>99 \%$ de similaridade foi relatado por Brinson e Messick 
(2001), porém estudos filogenéticos baseados no gene RNase P RNA demonstraram que o Mhc é uma espécie distinta que infecta cães (do Nascimento et al., 2012). Infelizmente não foi possível incluir genes adicionais no presente estudo filogenético, uma vez que não havia DNA suficiente das amostras de cães para amplificações adicionais.

O presente estudo representa o primeiro relato da ocorrência de hemoplasmas em cães da Nigéria junto com o sequenciamento do gene $16 S$ rRNA da espécie de haemoplasma encontrada nesses cães (Mhc). A avaliação dessas sequencias revelou pouca variabilidade genética na espécie Mycoplasma haemocanis. 


\subsection{CONCLUSÃO}

Em conclusão, a ocorrência de hemoplasmas em cães da Nigéria foi comparável a de outros países com clima quente similar. Uma identidade genética próxima existe entre as sequencias do gene 16S rRNA da espécie Mhc de diversas partes do mundo. O achado de não associação entre hemoplasmas caninos e anemia reforça a baixa patogenicidade das espécies de hemoplasmas caninas.

\section{Agradecimentos}

Os autores gostariam de agradecer Pam D. Mancha, Godwin A Ojoko e Dr Nembut Joy pela assistência técnica durante a amostragem. 


\section{REFERÊNCIAS BIBLIOGRÁFICAS}

Aquino, L.C., Hicks, C.A., Scalon, M.C., Lima, M.G., Lemos, M.D., Paludo, G.R., Helps, C.R., Tasker, S., 2014. Prevalence and phylogenetic analysis of haemoplasmas from cats infected with multiple species. J Microbiol Methods 107C, 189-196.

Barker, E.N., Langton, D.A., Helps, C.R., Brown, G., Malik, R., Shaw, S.E., Tasker, S., 2012. Haemoparasites of free-roaming dogs associated with several remote Aboriginal communities in Australia. BMC Vet Res 8,55 .

Barker, E.N., Tasker, S., Day, M.J., Warman, S.M., Woolley, K., Birtles, R., Georges, K.C., Ezeokoli, C.D., Newaj-Fyzul, A., Campbell, M.D., Sparagano, O.A., Cleaveland, S., Helps, C.R., 2010. Development and use of real-time PCR to detect and quantify Mycoplasma haemocanis and "Candidatus Mycoplasma haematoparvum" in dogs. Vet Microbiol $140,167-170$.

Beall, M.J., Chandrashekar, R., Eberts, M.D., Cyr, K.E., Diniz, P.P., Mainville, C., Hegarty, B.C., Crawford, J.M., Breitschwerdt, E.B., 2008. Serological and molecular prevalence of Borrelia burgdorferi, Anaplasma phagocytophilum, and Ehrlichia species in dogs from Minnesota. Vector borne and zoonotic diseases 8, 455-464.

Brinson, J.J., Messick, J.B., 2001. Use of a polymerase chain reaction assay for detection of Haemobartonella canis in a dog. Journal of the American Veterinary Medical Association 218, 1943-1945.

Budreckis, D.M., Byrne, B.A., Pollard, R.E., Rebhun, R.B., Rodriguez, C.O., Jr., Skorupski, K.A., 2015. Bacterial urinary tract infections associated with transitional cell carcinoma in dogs. J Vet Intern Med 29, 828-833.

Compton, S.M., Maggi, R.G., Breitschwerdt, E.B., 2012. Candidatus Mycoplasma haematoparvum and Mycoplasma haemocanis infections in dogs from the United States. Comp Immunol Microbiol Infect Dis 35, 557-562.

Criado-Fornelio, A., Martinez-Marcos, A., Buling-Saraña, A., Barba-Carretero, J.C., 2003. Presence of Mycoplasma haemofelis, Mycoplasma haemominutum and piroplasmids in cats from southern Europe: a molecular study. Vet Microbiol 93, 307-317.

do Nascimento, N.C., Santos, A.P., Guimaraes, A.M., Sanmiguel, P.J., Messick, J.B., 2012. Mycoplasma haemocanis--the canine hemoplasma and its feline counterpart in the genomic era. Vet Res 43, 66. 
Giangaspero, A., Marangi, M., Papini, R., Paoletti, B., Wijnveld, M., Jongejan, F., 2015. Theileria sp. OT3 and other tick-borne pathogens in sheep and ticks in Italy: molecular characterization and phylogeny. Ticks Tick Borne Dis 6, 75-83.

Hetzel, N.J., Barker, E.N., Helps, C.R., Tasker, S., Arteaga, A., Barrs, V.R., Beatty, J., 2012. Prevalence of canine haemotropic mycoplasma infections in Sydney, Australia. Vet Rec 171, 126.

Hii, S.F., Kopp, S.R., Thompson, M.F., O'Leary, C.A., Rees, R.L., Traub, R.J., 2012. Canine vector-borne disease pathogens in dogs from south-east Queensland and north-east Northern Territory. Australian Veterinary Journal 90, 130-135.

Inokuma, H., Oyamada, M., Davoust, B., Boni, M., Dereure, J., Bucheton, B., Hammad, A., Watanabe, M., Itamoto, K., Okuda, M., Brouqui, P., 2006. Epidemiological survey of Ehrlichia canis and related species infection in dogs in eastern Sudan. Annals of the New York Academy of Sciences 1078, 461-463.

Kamani, J., Baneth, G., Mumcuoglu, K.Y., Waziri, N.E., Eyal, O., Guthmann, Y., Harrus, S., 2013. Molecular detection and characterization of tickborne pathogens in dogs and ticks from Nigeria. PLoS neglected tropical diseases 7 , e2108.

Kemming, G., Messick, J.B., Mueller, W., Enders, G., Meisner, F., Muenzing, S., Kisch-Wedel, H., Schropp, A., Wojtczyk, C., Packert, K., Messmer, K., Thein, E., 2004a. Can we continue research in splenectomized dogs? Mycoplasma haemocanis: old problem--new insight. European surgical research. Europaische chirurgische Forschung. Recherches chirurgicales europeennes 36, 198-205.

Kemming, G.I., Messick, J.B., Enders, G., Boros, M., Lorenz, B., Muenzing, S., Kisch-Wedel, H., Mueller, W., Hahmann-Mueller, A., Messmer, K., Thein, E., 2004b. Mycoplasma haemocanis infection - a kennel disease? Comparative Medicine 54, 404-409.

Kenny, M.J., Shaw, S.E., Beugnet, F., Tasker, S., 2004. Demonstration of two distinct hemotropic mycoplasmas in French dogs. J Clin Microbiol 42, 5397-5399.

Lobetti, R.G., Joubert, K.E., Picard, J., Carstens, J., Pretorius, E., 2002. Bacterial colonization of intravenous catheters in young dogs suspected to have parvoviral enteritis. J Am Vet Med Assoc 220, 13211324.

Messick, J.B., 2004. Hemotrophic mycoplasmas (hemoplasmas): a review and new insights into pathogenic potential. Vet Clin Pathol 33, 2-13. 
Messick, J.B., Walker, P.G., Raphael, W., Berent, L., Shi, X., 2002. 'Candidatus mycoplasma haemodidelphidis' sp. nov., 'Candidatus mycoplasma haemolamae' sp. nov. and Mycoplasma haemocanis comb. nov., haemotrophic parasites from a naturally infected opossum (Didelphis virginiana), alpaca (Lama pacos) and dog (Canis familiaris): phylogenetic and secondary structural relatedness of their 16S rRNA genes to other mycoplasmas. Int J Syst Evol Microbiol 52, 693-698.

Novacco, M., Meli, M.L., Gentilini, F., Marsilio, F., Ceci, C., Pennisi, M.G., Lombardo, G., Lloret, A., Santos, L., Carrapiço, T., Willi, B., Wolf, G., Lutz, H., Hofmann-Lehmann, R., 2010. Prevalence and geographical distribution of canine hemotropic mycoplasma infections in Mediterranean countries and analysis of risk factors for infection. Vet Microbiol 142, 276-284.

Ogo, N.I., de Mera, I.G., Galindo, R.C., Okubanjo, O.O., Inuwa, H.M., Agbede, R.I., Torina, A., Alongi, A., Vicente, J., Gortazar, C., de la Fuente, J., 2012. Molecular identification of tick-borne pathogens in Nigerian ticks. Veterinary parasitology 187, 572-577.

Perez, C., Fujii, Y., Fauls, M., Hummel, J., Breitschwerdt, E., 2011. Fatal aortic endocarditis associated with community-acquired Serratia marcescens infection in a dog. J Am Anim Hosp Assoc 47, 133-137.

Pitulle, C., Pace, N.R., 1999. T-cloning vector for plasmid-based 165 rDNA analysis. Biotechniques 26, 222-224.

Reye, A.L., Arinola, O.G., Hubschen, J.M., Muller, C.P., 2012. Pathogen prevalence in ticks collected from the vegetation and livestock in Nigeria. Applied and environmental microbiology 78, 2562-2568.

Roura, X., Peters, I.R., Altet, L., Tabar, M.D., Barker, E.N., Planellas, M., Helps, C.R., Francino, O., Shaw, S.E., Tasker, S., 2010. Prevalence of hemotropic mycoplasmas in healthy and unhealthy cats and dogs in Spain. J Vet Diagn Invest 22, 270-274.

Sasaki, M., Ohta, K., Matsuu, A., Hirata, H., Ikadai, H., Oyamada, T., 2008. A molecular survey of Mycoplasma haemocanis in dogs and foxes in Aomori Prefecture, Japan. The Journal of Protozoology Research 18, 57-60.

Sykes, J.E., Ball, L.M., Bailiff, N.L., Fry, M.M., 2005. 'Candidatus Mycoplasma haematoparvum', a novel small haemotropic mycoplasma from a dog. Int J Syst Evol Microbiol 55, 27-30.

Tasker, S., Helps, C.R., Day, M.J., Harbour, D.A., Shaw, S.E., Harrus, S., Baneth, G., Lobetti, R.G., Malik, R., Beaufils, J.P., Belford, C.R., Gruffydd-Jones, T.J., 2003. Phylogenetic analysis of hemoplasma species: an international study. J Clin Microbiol 41, 3877-3880. 
Tasker, S., Peters, I.R., Mumford, A.D., Day, M.J., Gruffydd-Jones, T.J., Day, S., Pretorius, A.M., Birtles, R.J., Helps, C.R., Neimark, H., 2010. Investigation of human haemotropic Mycoplasma infections using a novel generic haemoplasma QPCR assay on blood samples and blood smears. Journal of medical microbiology 59, 1285-1292.

Tennant, K.V., Barker, E.N., Polizopoulou, Z., Helps, C.R., Tasker, S., 2011. Real-time quantitative polymerase chain reaction detection of haemoplasmas in healthy and unhealthy dogs from Central Macedonia, Greece. J Small Anim Pract 52, 645-649.

Varanat, M., Maggi, R.G., Linder, K.E., Breitschwerdt, E.B., 2011. Molecular prevalence of Bartonella, Babesia, and hemotropic Mycoplasma sp. in dogs with splenic disease. Journal of Veterinary Internal Medicine 25, 1284-1291.

Warman, S.M., Helps, C.R., Barker, E.N., Day, S., Sturgess, K., Day, M.J., Tasker, S., 2010. Haemoplasma infection is not a common cause of canine immune-mediated haemolytic anaemia in the UK. J Small Anim Pract 51, 534-539.

Wengi, N., Willi, B., Boretti, F.S., Cattori, V., Riond, B., Meli, M.L., Reusch, C.E., Lutz, H., Hofmann-Lehmann, R., 2008. Real-time PCR-based prevalence study, infection follow-up and molecular characterization of canine hemotropic mycoplasmas. Vet Microbiol 126, 132-141. 
Tabela 2.1. Características dos cães amostrados e resultados da PCR

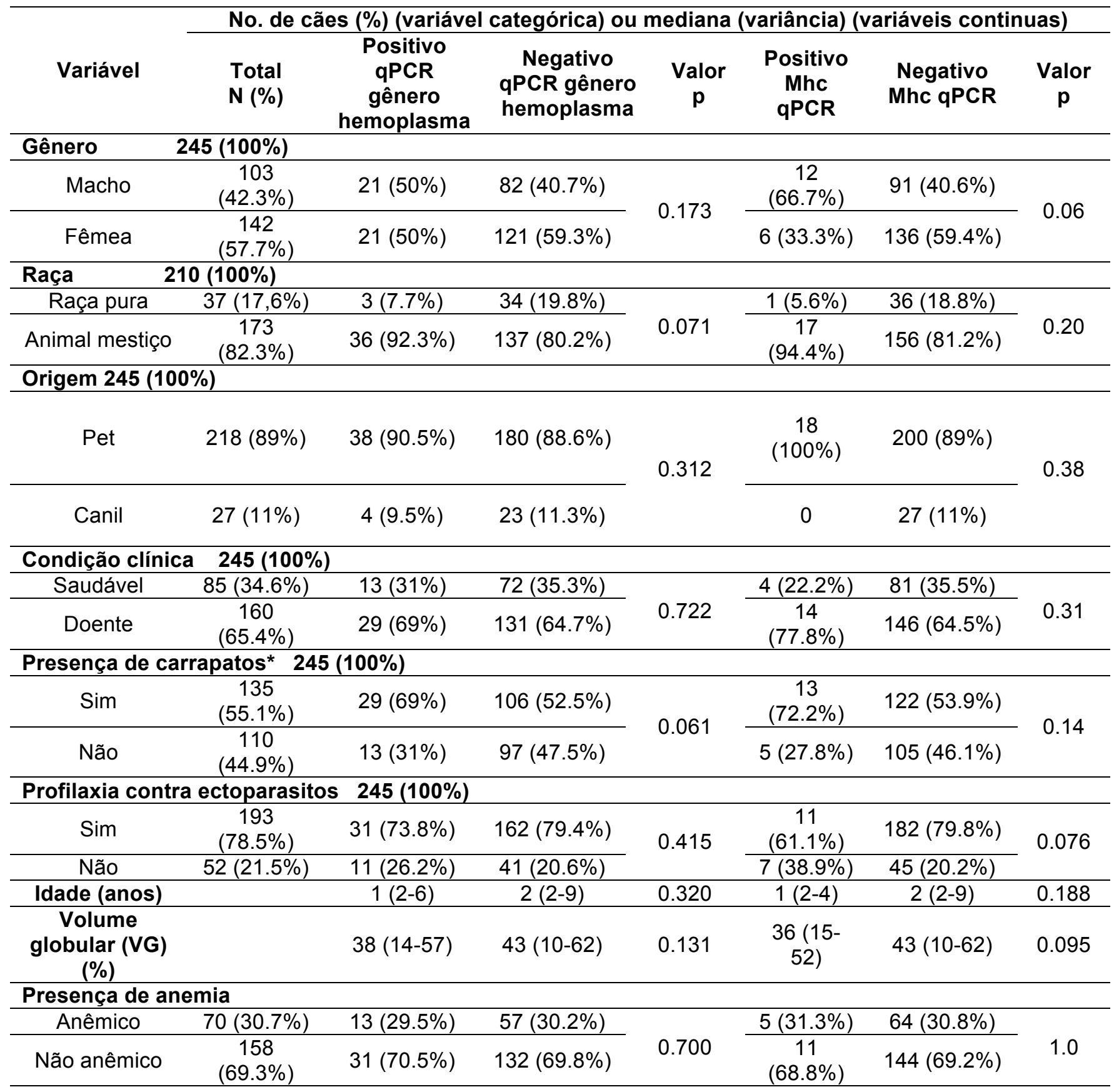

$\S$ Valor $p$ indica resultado do teste $x^{2}$ para variáveis categóricas e do teste Mann-Whitney U para variáveis contínuas

* Todos os carrapatos encontrados foram identificados como Rhipicephalus sanguineus 
Tabela 2.2. Percentual de amostras de sague de cães positivas para espécies de hemoplasmas (Mhc e CMhp) por PCR

\begin{tabular}{lcccc}
\hline Origem amostra & Total (\%) & Mhc (\%) & CMhp (\%) & $\begin{array}{c}\text { Mhc e } \\
\text { CMhp (\%) }\end{array}$ \\
\hline Nigéria (presente estudo) & 17,1 & 7,3 & 0,4 & - \\
França & 15,4 & 5,9 & 12 & 2,6 \\
Espanha & 14,3 & 14,3 & 0,6 & 0,6 \\
Tanzânia & 20 & 19 & - & 0.01 \\
Suíça & 1,2 & 0,9 & 0,3 & - \\
Grécia & 10,6 & 5,6 & 4,2 & 0,7 \\
Trinidade & 8,7 & 4,9 & 2,7 & 1,1 \\
Itália & 9,5 & 3,7 & 5 & 0,8 \\
Portugal & 40 & 40 & - & - \\
Austrália & 64 & 43,6 & 20,5 & -
\end{tabular}

CMhp = "Candidatus Mycoplasma haematoparvum"

Mhc $=$ Mycoplasma haemocanis 
Figura 2.1. Relações filogenéticas das sequencias do gene $16 \mathrm{~S}$ rRNA de hemoplasmas previamente publicadas e de Mhc de cães da Nigéria. Valores de porcentagem de bootstrap estão nos nodos da árvore flogenética (apenas valores $>700$ estão apresentados). As distâncias evolucionárias estão representadas na escala. Clostridium spp. foi usado como grupo externo. Os números de acesso ao GenBank estão indicados na figura. Sequencias de Mhc dos animais F2, G7, H7 e E8 foram geradas no presente estudo. Número de acesso ao nucleotídeo no Genbank (KP715857, KP715858, KP715859 and KP715860). Mhc $=$ Mycoplasma haemocanis, $\mathrm{CMhp}=$ "Candidatus Mycoplasma haematoparvum", Mhf = Mycoplasma haemofelis, $\mathrm{CMhm}=$ "Candidatus Mycoplasma haemominutum"

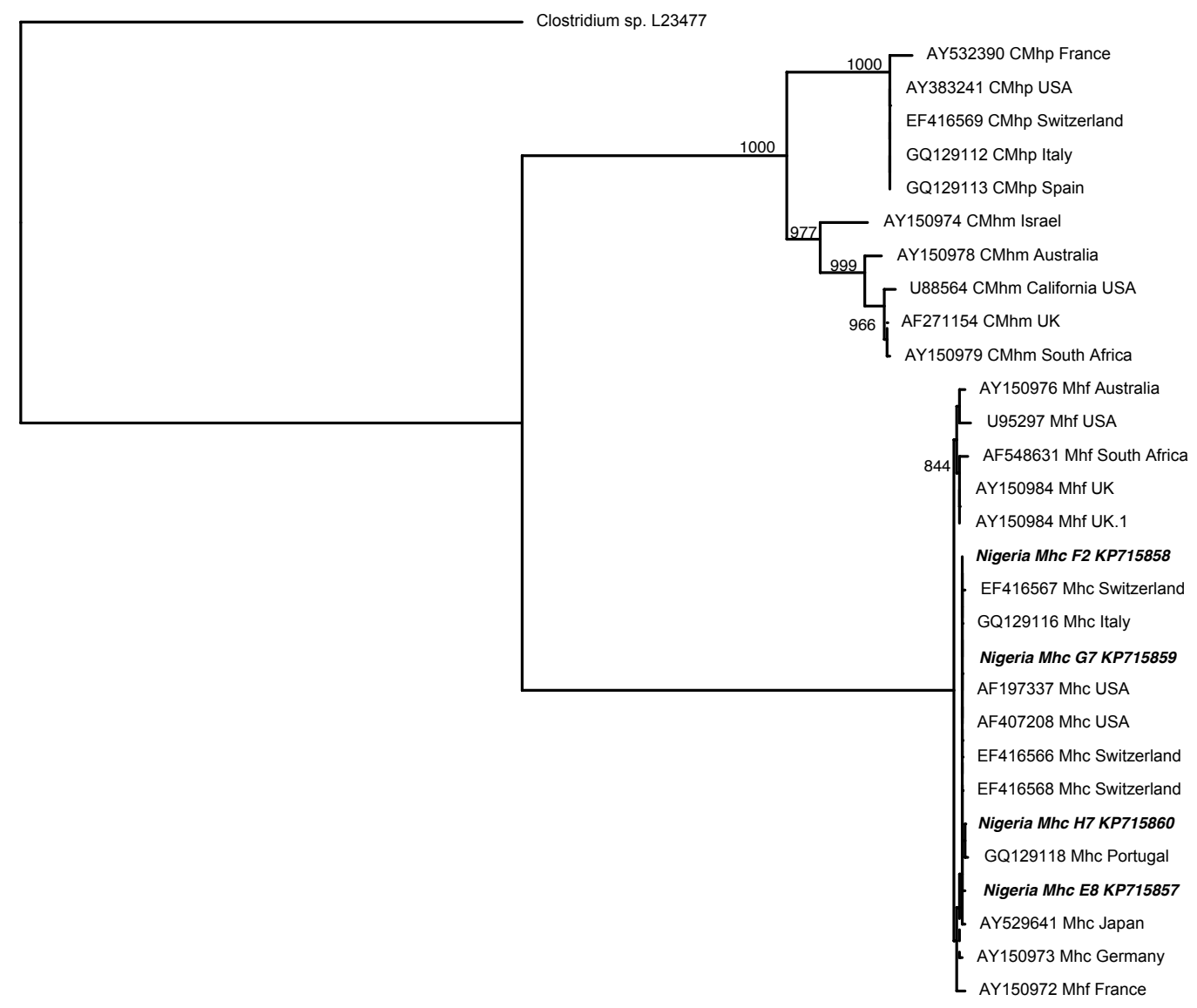




\title{
Prevalence and phylogenetic analysis of haemoplasmas from cats infected with multiple species
}

\author{
Larissa Campos Aquino a,*, Chelsea A.E. Hicks ${ }^{\text {b }}$, Marcela C. Scalon ${ }^{\text {a }}$, Maíra G. da M. Lima a , \\ Marcelle dos S. Lemos ${ }^{a}$, Giane Regina Paludo ${ }^{a}$, Chris R. Helps ${ }^{\mathrm{b}, \mathrm{c}}$, Séverine Tasker ${ }^{\mathrm{b}, \mathrm{c}}$ \\ a Laboratory of Veterinary Clinical Pathology, College of Agronomy and Veterinary Medicine, University of Brasília, Campus Universitário Darcy Ribeiro, Brasília 709010-900, Brazil
b School of Veterinary Sciences, University of Bristol, Langford House, Langford, Bristol BS40 5DU, UK \\ ${ }^{c}$ Molecular Diagnostic Unit, Langford Veterinary Services, Langford, Bristol BS40 5DU, UK
}

\section{A R T I C L E I N F O}

\section{Article history:}

Received 7 September 2014

Received in revised form 27 October 2014

Accepted 28 October 2014

Available online 4 November 2014

\section{Keywords:}

Haemoplasmas

Brazil

Cats

Prevalence

Co-infections

\begin{abstract}
A B S T R A C T
Mycoplasma haemofelis (Mhf), ‘Candidatus Mycoplasma haemominutum’ (CMhm) and ‘Candidatus Mycoplasma turicensis' (CMt) are agents of feline haemoplasmosis and can induce anaemia in cats. This study aimed to determine the prevalence and phylogeny of haemoplasma species in cats from Brazil's capital and surrounding areas, and whether correlation with haematological abnormalities existed. Feline haemoplasmas were found in $13.8 \%$ of 432 cats. CMhm was the most prevalent species (in 13.8\% of cats), followed by Mhf (11.1\%) and CMt (4.4\%). Over $80 \%$ of haemoplasma-infected cats harboured two or more feline haemoplasma species: $7.1 \%$ of cats were co-infected with Mhf/CMhm, $0.4 \%$ with CMhm/CMt and 3.9\% with Mhf/CMhm/CMt. Male gender was significantly associated with haemoplasma infections. No association was found between qPCR haemoplasma status and haematological variables, however CMhm relative copy numbers were correlated with red blood cell (RBC) numbers and packed cell volume (PCV). Haemoplasma 16S rRNA gene sequences $(>1 \mathrm{~Kb})$ were derived from co-infected cats using novel haemoplasma species-specific primers. This allowed 16S rRNA gene sequences to be obtained despite the high level of co-infection, which precluded the use of universal 16S rRNA gene primers. Within each species, the Mhf, CMhm and CMt sequences showed $>99.8 \%,>98.5 \%$ and $>98.8 \%$ identity, respectively. The Mhf, CMhm and CMt sequences showed $>99.2 \%,>98.4 \%$ and $>97.8 \%$ identity, respectively, with GenBank sequences. Phylogenetic analysis showed all Mhf sequences to reside in a single clade, whereas the $\mathrm{CMhm}$ and $\mathrm{CMt}$ sequences each grouped into three distinct subclades. These phylogeny findings suggest the existence of different CMhm and CMt strains.
\end{abstract}

(c) 2014 The Authors. Published by Elsevier B.V. This is an open access article under the CC BY license (http://creativecommons.org/licenses/by/3.0/).

\section{Introduction}

Haemoplasmas are haemotropic mycoplasmas lacking a cell wall that attach and grow on the surface of red blood cells and can cause infectious anaemia in different mammalian species. Although some of their basic characteristics are known (Messick, 2004), they have not yet been successfully cultivated in vitro. Three main haemoplasma species can infect cats: Mycoplasma haemofelis (Mhf), 'Candidatus Mycoplasma haemominutum' (CMhm) and 'Candidatus Mycoplasma turicensis' (CMt). Mhf is the most pathogenic, often leading to haemolytic anaemia during acute infection. In contrast, CMhm and CMt are less pathogenic, but when combined with Mhf or retrovirus infection may also induce anaemia (Tasker et al., 2009).

Haemoplasmas are found throughout the world and have previously been identified in cats (Biondo et al., 2009a), dogs (Biondo et al., 2009a), cattle (Girotto et al., 2012), capybaras (Vieira et al., 2009), lions

\footnotetext{
* Corresponding author.

E-mail address: larissaquino@gmail.com (L.C. Aquino).
}

(Guimaraes et al., 2007) and deer (Grazziotin et al., 2011) in Brazil. Recently, the zoonotic potential of haemoplasmas has been reported after the molecular identification of haemoplasmas in immunosuppressed humans and professionals, some with frequent exposure to haemoplasma infected animals (dos Santos et al., 2008; Steer et al., 2011; Sykes et al., 2010). Moreover, domestic cats may act as a source of haemoplasma infection for wild animals (André et al., 2014).

Previous studies have reported the prevalence of haemoplasmas in domestic cats from different Brazilian states such as Mato Grosso do Sul (MS) (36.4\%) (Santis et al., 2014), Rio de Janeiro (RJ) (12\%) (Macieira et al., 2008), Rio Grande do Sul (RS) (21.3\%) (Santos et al., 2009), Maranhão (MA) (12\%) (Braga et al., 2012), São Paulo (SP) (32\% and 6.5\%) (André et al., 2014; de Bortoli et al., 2012) and Mato Grosso (MT) (8.4\%) (Miceli et al., 2013). However these studies have not consistently reported haematological findings or phylogenetic analysis. In those that have evaluated phylogeny, only short (less than $600 \mathrm{bp}$ ) 16S rRNA gene sequences have been used (André et al., 2014; Miceli et al., 2013; Santis et al., 2014) or sequences were not submitted to GenBank (Braga et al., 2012). Additionally, few positive cats and no 
more than two reference sequences for each haemoplasma species were used in phylogenetic analysis. Further work on the phylogeny of Brazilian feline haemoplasmas is required, using (near) complete $16 \mathrm{~S}$ rRNA and other genes if possible. The aim of this study was to assess the prevalence and phylogeny of haemoplasmas from naturally infected cats in Brazil's capital, Brasília, and surrounding areas, and to determine whether any correlation existed between haemoplasma infection and haematological abnormalities.

\section{Materials and methods}

\subsection{Sample collection}

From 2009 to 2013, EDTA-anticoagulated feline blood samples were obtained from the following groups in order to acquire as large and diverse a population of samples as possible: i) cats from Brazil's capital, Brasília, and surrounding areas that attended the local veterinary teaching hospital or private clinics, ii) owned cats from 7 cities in the surrounding areas seen during the 2012 and 2013 anti-rabies vaccination campaign, iii) owned cats from one city village outside Brasília sampled during a leishmaniasis surveillance programme conducted by the public health service, and iv) feral cats from a shelter located in Brasília's surrounding area.

\subsection{Ethics Approval}

Data regarding gender were available but not health status or age. The project was approved by the University of Brasillia (UnB) ethics committee under the protocol number UnBDOC no. 43938/2012.

\subsection{Haematological analysis}

Haemoglobin concentration and red blood cell (RBC) numbers were determined using a semi-automatic veterinary blood cell counter ( $A B C$ Vet-Horiba ${ }^{\circledR}$ ABX diagnostics, Brazil) and the packed cell volume (PCV) was determined by microhaematocrit centrifugation. Mean corpuscular volume (MCV) and mean corpuscular haemoglobin concentration (MCHC) were calculated from haemoglobin, PCV and red blood cell count. Anaemia was defined as a PCV $<24 \%$.

\subsection{DNA extraction}

DNA extraction from $100 \mu \mathrm{L}$ of blood was performed using a commercial kit (Illustra blood genomicPrep Mini Spin Kit, GE Healthcare, UK) according to the manufacturer's instructions. The DNA was eluted with $100 \mu \mathrm{L}$ of elution buffer provided with the commercial kit and stored at $-20{ }^{\circ} \mathrm{C}$ prior to analysis.

\subsection{Control and generic haemoplasma conventional PCR assays}

In order to check for the presence of PCR inhibitors and evaluate the DNA quality, all samples were subjected to a control conventional PCR to amplify a fragment of the glyceraldehyde-3-phosphate dehydrogenase (GAPDH) gene using primers described by Birkenheuer et al. (2003), as part of another previous study assessing DNA extraction efficiency. The protocol for this PCR included the following: $1 \mu \mathrm{L}$ of DNA template was amplified using $0.5 \mu \mathrm{M}$ of each primer, $1.25 \mathrm{U}$ Taq DNA Polymerase recombinant, $0.2 \mathrm{mM}$ dNTPs, $1 \times$ PCR buffer and $1.5 \mathrm{mM}$ $\mathrm{MgCl}_{2}$ (all Invitrogen ${ }^{\mathrm{TM}}$ ), with water to $25 \mu \mathrm{L}$. Amplification was performed in a thermal-cycler (FTGene5D, Techgene, UK) with an initial denaturation step of $94{ }^{\circ} \mathrm{C}$ for $5 \mathrm{~min}$, followed by 40 cycles of denaturation $\left(94{ }^{\circ} \mathrm{C} ; 30 \mathrm{~s}\right)$, annealing $\left(52{ }^{\circ} \mathrm{C} ; 1 \mathrm{~min}\right)$, extension $\left(72{ }^{\circ} \mathrm{C} ; 1 \mathrm{~min}\right)$ and a final extension at $72{ }^{\circ} \mathrm{C}$ for $5 \mathrm{~min}$. Water was used as a negative control and DNA extracted from non-infected cat blood as a positive control. Samples giving bands of $400 \mathrm{bp}$ on a $1.5 \%$ agarose gel stained with ethidium bromide were considered positive and, therefore, had DNA of sufficient quantity and quality for further molecular analysis.

Following GAPDH conventional PCR, DNA samples were then screened for haemoplasma infection using a generic haemoplasma conventional PCR adapted from Criado-Fornelio et al. (2003) to amplify 595 bp fragments of the 16S rRNA gene. In the reaction, $2 \mu \mathrm{L}$ of DNA template was amplified using $0.5 \mu \mathrm{M}$ of each primer, 1.0 U Taq DNA Polymerase recombinant, $0.25 \mathrm{mM}$ dNTPs, $1 \times$ PCR buffer and $2.5 \mathrm{mM}$ $\mathrm{MgCl}_{2}$ (all Invitrogen ${ }^{\mathrm{TM}}$ ), with water to $25 \mu \mathrm{L}$. Amplification was performed in a thermal-cycler (FTGene5D, Techgene, UK) with an initial denaturation step of $94^{\circ} \mathrm{C}$ for $10 \mathrm{~min}$, followed by 40 cycles of denaturation $\left(94{ }^{\circ} \mathrm{C} ; 30 \mathrm{~s}\right)$, annealing $\left(50{ }^{\circ} \mathrm{C} ; 30 \mathrm{~s}\right)$, extension $\left(72{ }^{\circ} \mathrm{C} ; 30 \mathrm{~s}\right)$ and a final extension at $72{ }^{\circ} \mathrm{C}$ for $10 \mathrm{~min}$. Water was used as negative control and DNA from a naturally infected haemoplasma cat previously diagnosed by cytology and PCR (species not defined) was used as a positive control. PCR products underwent electrophoresis in a $1.5 \%$ agarose gel stained with ethidium bromide, and samples with fragments of $595 \mathrm{bp}$ were identified as positive.

2.6. Haemoplasma species-specific real-time quantitative PCR assays and relative copy number determination

All of the DNA samples generating positive results by the conventional generic PCR were shipped to the University of Bristol, UK for subsequent real-time quantitative PCR (qPCR) as previously described (Peters et al., 2008b) to identify the haemoplasma species (Mhf, $\mathrm{CMhm}$ and/or CMt) present and determine relative copy numbers. All qPCR reactions were duplexed with an internal control (feline 28S rRNA gene) assay to demonstrate the presence of amplifiable DNA and the absence of PCR inhibitors; a threshold cycle (Ct) value of 22 was used as a cut off. In each run, DNA from known haemoplasma positive cats was used as a positive control and water as a negative control.

Relative copy numbers were calculated using the $E^{\Delta C t}$ equation, with the assumption that the highest $\mathrm{Ct}$ in the sample set equalled 1 haemoplasma copy/reaction $(\Delta \mathrm{Ct}=$ highest $\mathrm{Ct}-$ sample $\mathrm{Ct})$ and taking into account the Mhf, CMhm and CMt qPCR reaction efficiencies (E) previously determined (Peters et al., 2008b) from standard curves.

\section{7. $16 \mathrm{~S}$ rRNA gene sequencing}

The $11 \mathrm{CMt}, 10 \mathrm{Mhf}$ and $10 \mathrm{CMhm}$ positive samples representing different geographical locations with the lowest $\mathrm{Ct}$ values were chosen for $16 \mathrm{~S}$ rRNA gene amplification and sequencing. However, in order to sequence the 16S rRNA gene of individual haemoplasma species from the many cats with haemoplasma co-infections, species-specific $16 \mathrm{~S}$ rRNA gene primers were designed to amplify around $1200 \mathrm{bp}$ of the 16S rRNA gene through a conventional PCR. Briefly, complete 16S rRNA gene sequences from feline haemoplasma species available on GenBank (accession numbers AY831867, DQ157150, DQ157151, DQ464417, DQ464418, DQ464419, DQ464420, DQ464421, DQ464422, DQ464423, DQ464424, DQ464425, AF271154, AY150974, AY150978, AY150979, AY150980, AY150981, U88564, AF178677, AF548631, AY069948, AY150972, AY150976, AY150977, AY150984, AY150985, U88563, U95297) were downloaded and aligned using Clustal-W on MacVector ver 13.0.3. The consensus sequence generated for each of the three feline haemoplasma species was used to manually identify the most specific regions of the $16 \mathrm{~S}$ rRNA gene to which species specific primer pairs could be designed. Short sequences ranging from 25 to $30 \mathrm{bp}$ were selected as forward and reverse primers and tested using Primer3 (web version 4.0.0; http://primer3.ut.ee/) against the consensus sequence to obtain primer pairs with suitable melting temperatures (Tm), self-complementarity, 3' self-complementarity and hairpin formation.

Two primer pairs for each feline haemoplasma species were selected for evaluation based on their predicted product size, Tm and minimal pair complementarity (Table 1 ). The primer specificities were first 
Table 1

16S rRNA gene primer sequences designed for haemoplasma species-specific conventional PCR amplification of haemoplasma DNA from positive cats for the 16S rRNA gene sequencing.

\begin{tabular}{|c|c|c|c|}
\hline Primer name & Primer sequence & $\begin{array}{l}\mathrm{Tm}^{\mathrm{b}} \\
\left({ }^{\circ} \mathrm{C}\right)\end{array}$ & $\begin{array}{l}\text { Product size } \\
\text { (bp) }\end{array}$ \\
\hline MhfFw1 & GCTGATGGTATGCCTAATACATGC & 59 & 1336 \\
\hline MhfRev1 & GCCСАСТССТСTCATAGTTTGA & & \\
\hline MhfFw2 ${ }^{\mathrm{a}}$ & CGAACGGACTTTGGTTTCGG & 59 & 1214 \\
\hline MhfRev $2^{\mathrm{a}}$ & CTTCAAGGAGGCGAATTGCAG & & \\
\hline CMhmFw1 & TACTCTCTTAGTGGCGAACGG & 60 & 1314 \\
\hline CMhmRev1 & CTCCCATAGTTTGACGGGCG & & \\
\hline $\mathrm{CMhmFw}^{\mathrm{a}}$ & AGGGTTTACTCTCTTAGTGGCG & 59 & 1375 \\
\hline CMhmRev2 ${ }^{\mathrm{a}}$ & TCCAGTCAAAATTACCAATCTAGACG & & \\
\hline CMtFw1 & CTGTCCAAAAGGCAGTTAGCG & 59 & 1312 \\
\hline CMtRev1 & TGTGTTTTCAAATGCCCCTTCC & & \\
\hline $\mathrm{CMtFw} 2^{\mathrm{a}}$ & GTCCTATAGTATCCTCCATCAGACAG & 59 & 1039 \\
\hline CMtRev2 ${ }^{\mathrm{a}}$ & CGACACATTGTACTCACCATTGTAA & & \\
\hline Internal forward & GGGATTAGATACCCCAGTAGTCCAC & 59 & 600 \\
\hline Internal reverse & GTGGACTACTGGGGTATCTAATCCC & & \\
\hline
\end{tabular}

a Primers selected as external primers for sequencing.

b $\mathrm{Tm}=$ melting temperature.

tested by BLAST searching against all existing DNA sequences stored in GenBank and subsequently each primer pair was subjected to PCR with a template of as high relative copy number as possible available $\left(10^{7}\right.$ of $\mathrm{CMhm}, 10^{7}$ of Mhf or $10^{4}$ of $\mathrm{CMt}$ ) of their non-target feline haemoplasma species to evaluate cross-reactivity. The selected primers were tested in a $25 \mu \mathrm{L}$ reaction containing $12.5 \mu \mathrm{L}$ of $2 \times$ Promega GoTaq ${ }^{\circledR}$ Hot Start Colorless Master Mix (USA) with $0.2 \mu \mathrm{M}$ of each primer and $1 \mu \mathrm{L}$ of DNA template, to a final volume of $25 \mu \mathrm{L}$ with water. The reaction was performed on a SureCycler 8800 thermal cycler (Agilent Technologies, USA) with cycling conditions as follows: $95^{\circ} \mathrm{C}$ for $5 \mathrm{~min}$, followed by 45 cycles of amplification $\left(95^{\circ} \mathrm{C}, 10 \mathrm{~s} ; 62^{\circ} \mathrm{C}, 30 \mathrm{~s} ; 72^{\circ} \mathrm{C}\right.$ $90 \mathrm{~s}$ ) with final extension of $72{ }^{\circ} \mathrm{C}$ for $5 \mathrm{~min}$. Cats singly infected with Mhf, CMhm and CMt, previously identified by the species-specific qPCR assays and water, were used as positive and negative controls, respectively. Products were identified by electrophoresis in a $1.5 \%$ agarose gel stained with ethidium bromide.

PCR products of the expected $\sim 1200$ bp size were purified with the NucleoSpin ${ }^{\circledR}$ Gel and PCR Clean-up kit (MACHEREY NAGEL GmbH \& Co.) according to the manufacturer's instructions, quantified with a Qubit ${ }^{\mathrm{TM}}$ fluorometer (Invitrogen ${ }^{\mathrm{TM}}$ ) and submitted to the DNA Sequencing \& Service (MRCPPU, College of Life Sciences, University of Dundee, Scotland, www.dnaseq.co.uk) for sequencing using an Applied Biosystems Big-Dye Ver 3.1 chemistry on an Applied Biosystems model 3730 automated capillary DNA sequencer. Sequencing was performed in the sense and antisense directions using the external species-specific primers (MhfFw2/MhfRev2, CMhmFw2/CMhmRev2, CMtFw2/CMtRev2) and internal primers (Table 1). The internal primers were manually designed in highly conserved regions of the 16S rRNA gene after alignment of 16S rRNA gene sequences from the three haemoplasmas species and checked using Primer3.

\subsection{Phylogenetic analysis}

Sequence editing and analysis were performed in MacVector v13.0.3, Inc. Reconstruction of near-complete 16S rRNA gene sequences for the $11 \mathrm{CMt}, 10 \mathrm{Mhf}$ and $10 \mathrm{CMhm}$ positive samples was performed by combining individual sequences derived from the external and internal primers. These newly derived $16 \mathrm{~S}$ rRNA gene sequences and the $16 \mathrm{~S}$ rRNA gene haemoplasma species sequences available from GenBank were then aligned using Clustal-W. The phylogenetic tree was generated using the Neighbor-Joining method from a P-distance matrix and with data resampled 1000 times to estimate the confidence of branching patterns.

The novel haemoplasma 16S rRNA gene sequences generated in this study were submitted to GenBank under the following nucleotide accession numbers: Mhf sequences (KM275238-KM275247), CMhm sequences (KM275248-KM275257) and CMt sequences (KM275258KM275268).

\subsection{Statistics}

In order to accurately determine the prevalence of haemoplasmas, the sample size required was estimated according to Thrusfield (1986) and based on prior evidence (Barker et al., 2010; Biondo et al., 2009b) with precision of $5 \%$ and $95 \%$ confidence intervals.

Data were entered into Excel ${ }^{\circledR}$ and statistical evaluation was carried out using SPSS for Windows (SPSS Inc., Chicago IL, USA). Categorical variables (gender, conventional PCR and qPCR status) prevalence values were calculated together with 95\% confidence intervals using the Clopper-Pearson exact binomial method and differences were analysed by $X^{2}$ test. Cats were divided into five groups according to haemoplasma status based on the qPCR qualitative results generated: haemoplasma negative, CMhm only infected, CMhm and Mhf co-infected, CMhm and CMt co-infected, and CMhm, Mhf and CMt co-infected (no Mhf only infected or CMt only infected cats were found). The Kolmogorov-Smirnov test was used to test for normal distribution of continuous variables (PCV, RBC, haemoglobin concentration, MCV and MCHC). Kruskal-Wallis testing was used to determine if there were any significant differences among the haemoplasma status groups for non-normally distributed continuous haematological variables. Spearman's test was used to assess correlation in non-normally distributed data. Significance was assigned as a p value $<0.05$.

\section{Results}

It was estimated that a sample size of 349 cats was needed to reliably determine the prevalence of feline haemoplasmas in Brasília and surrounding areas. From 2009 to 2013, 451 cats were sampled.

Generic haemoplasma conventional PCR and haemoplasma speciesspecific qPCR results are shown in Table 2. All 451 samples were positive for GAPDH DNA by conventional PCR. Of the 451 cats sampled, 80 (17.7\%) were haemoplasma positive by the generic haemoplasma PCR. However, due to sample volume limitations, only 61 of these 80 haemoplasma positive samples could be subsequently subjected to haemoplasma species-specific qPCR. Thus 432 cats comprised the final study population. Gender data were not available for 70 cats; of the remaining 362 cats, 176 (48.62\%) were female and 186 (51.38\%) were

Table 2

Number and percentage of cats generating positive PCR results for haemoplasma species using both conventional and quantitative (q) PCR assays.

\begin{tabular}{lll}
\hline $\begin{array}{l}\text { PCR assay/haemoplasma } \\
\text { species found }\end{array}$ & $\begin{array}{l}\text { Number of haemoplasma } \\
\text { positives samples (\%) }\end{array}$ & $\begin{array}{l}\text { 95\% confidence } \\
\text { intervals }\end{array}$ \\
\hline $\begin{array}{l}\text { Generic haemoplasma } \\
\text { conventional PCR }\end{array}$ & $80 / 451(17.7 \%)$ & $14.2-21.3 \%$ \\
$\begin{array}{l}\text { Haemoplasma } \\
\text { species-specific qPCR }\end{array}$ & $60 / 432(13.8 \%)$ & $10.2-16.4 \%$ \\
Any Mhf & $48 / 432(11.1 \%)^{\mathrm{a}}$ & $7.8-13.5 \%$ \\
Any CMhm & $60 / 432(13.8 \%)^{\mathrm{a}}$ & $10.2-16.4 \%$ \\
Any CMt & $19 / 432(4.4 \%)^{\mathrm{b}}$ & $2.4-6.1 \%$ \\
Mhf alone & 0 & 0 \\
CMhm alone & $10 / 432(2.3 \%)$ & $0.9-3.6 \%$ \\
CMt alone & 0 & 0 \\
Mhf and CMhm & $31 / 432(7.1 \%)$ & $4.5-9.2 \%$ \\
CMhm and CMt & $2 / 432(0.4 \%)$ & $-0.02-1.1 \%$ \\
Mhf and CMt & 0 & 0 \\
Mhf and CMhm and CMt & $17 / 432(3.9 \%)$ & $2-5.5 \%$ \\
\hline
\end{tabular}

Mhf = Mycoplasma haemofelis.

$\mathrm{CMhm}=$ "Candidatus Mycoplasma haemominutum".

$\mathrm{CMt}=$ "Candidatus Mycoplasma turicensis".

${ }^{a}$ No significant difference $(\mathrm{p}=0.2)$ present between the groups labelled with this suffix.

b Significant difference $(\mathrm{p}=0.0002)$ present between this group and those with different suffix. 
male. All 61 qPCR-tested samples were positive for $28 \mathrm{~S}$ rRNA gene at a $\mathrm{Ct}$ of $\leq 22$. Sixty of the 61 samples were haemoplasma positive for any species by qPCR, representing an overall prevalence of haemoplasma infection of $13.8 \%$ in the 432 cats. Only one cat was positive in the generic haemoplasma PCR but not in any of the haemoplasma species-specific qPCRs. Of the 432 cats, 48 were positive for Mhf, 60 for CMhm and 19 for CMt, representing overall prevalences of $11.1 \%, 13.8 \%$ and $4.4 \%$, respectively for each haemoplasma species. The CMt prevalence was significantly lower $(p=0.0002)$ than that of CMhm and Mhf, but no significant difference was observed between the prevalences of CMhm and Mhf (Table 2). There was a very high proportion of cats with dual or triple haemoplasma co-infections, with 50 out of the 60 (83\%) haemoplasma infected cats being infected with more than one species, and no cats were solely infected with either Mhf or CMt. Of 432 cats, 17 (3.9\%) were triple infected with Mhf, CMhm and CMt, 31 (7.1\%) were dual infected with Mhf and CMhm, and two cats (0.4\%) were dual infected with CMhm and CMt. All of the negative and positive controls gave appropriate results in all PCRs.

There was a statistically significant relationship between the haemoplasma species-specific qPCR result and gender. Male cats had a significantly higher overall haemoplasma infection prevalence $(\mathrm{p}=0.01)$, as well as being more likely to be Mhf positive $(\mathrm{p}=$ $0.004)$, CMhm positive $(p=0.009)$ and CMt positive $(p=0.03)$, than female cats.

A wide range of relative copy numbers was found for all three haemoplasma species: Mhf-infected cats had relative copy numbers ranging from $0.2 \times 10^{0}$ to $2.54 \times 10^{8}$ relative copies/ $\mu$ l of blood, CMhm-infected cats from $0.2 \times 10^{0}$ to $2.32 \times 10^{8} / \mu$ and CMt-infected cats from $0.2 \times 10^{0}$ to $1.38 \times 10^{8} / \mu \mathrm{l}$ (Fig. 1 ).

Haematological data (PCV, RBC, haemoglobin, MCV and MCHC) were available for 420 cats (Table 3 ) and all variables were found to be non-normally distributed. No significant difference in haematological variables was found among the cats grouped according to haemoplasma status (Table 3). No significant correlation was found between haemoglobin concentration and the relative copy numbers of Mhf $\left(\mathrm{n}=45, \mathrm{r}_{\mathrm{s}}=0.127, \mathrm{p}=0.4\right)$, CMhm $\left(\mathrm{n}=57, \mathrm{r}_{\mathrm{s}}=0.246, \mathrm{p}=0.065\right)$ or CMt $\left(\mathrm{n}=17, \mathrm{r}_{\mathrm{s}}=-0.032, \mathrm{p}=0.903\right)$, although significance was approached for CMhm. Correlation data between PCV and the relative copy numbers for Mhf ( $\left.\mathrm{n}=45, \mathrm{r}_{\mathrm{s}}=0.031, \mathrm{p}=0.837\right)$, CMhm $(\mathrm{n}=$ $\left.57, r_{s}=0.294, p=0.027\right)$ or CMt $\left(n=17, r_{s}=-0.101, p=0.7\right)$

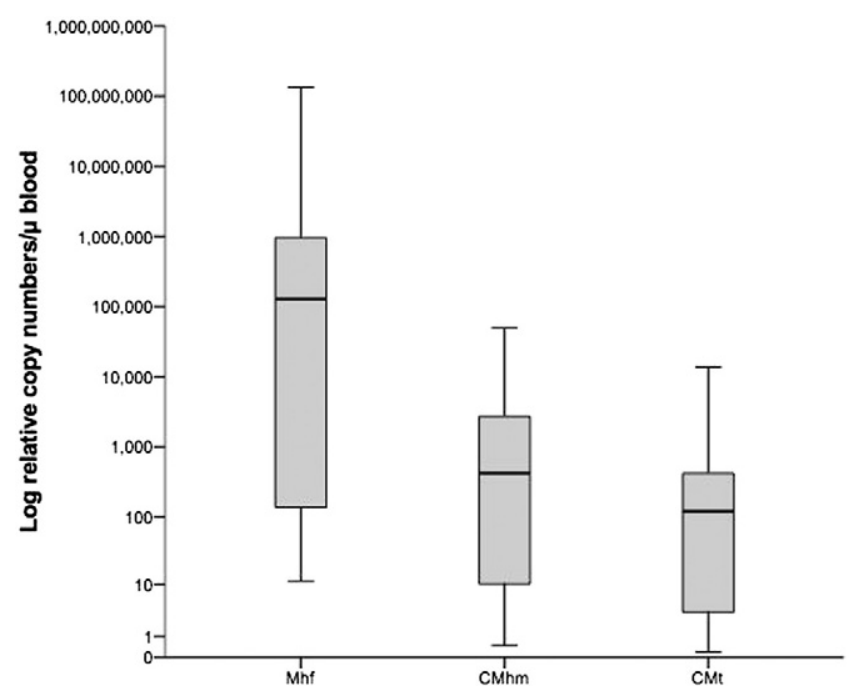

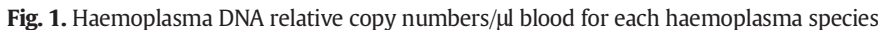
from samples generating positive results. Boxes represent the 25th, 50th (median) and 75th quartiles with whiskers extending to the greatest and smallest values. Mhf $=$ cats qPCR positive for Mycoplasma haemofelis, CMhm = cats qPCR positive for "Candidatus Mycoplasma haemominutum", CMt = cats qPCR positive for "Candidatus Mycoplasma turicensis". revealed a significant correlation for CMhm only, as did correlation data for RBC (Mhf [ $\left.\mathrm{n}=45, \mathrm{r}_{\mathrm{s}}=0.048, \mathrm{p}=0.752\right]$, CMhm [n=57, $\left.\mathrm{r}_{\mathrm{s}}=0.276, \mathrm{p}=0.038\right]$ or CMt $\left.\left[\mathrm{n}=17, \mathrm{r}_{\mathrm{s}}=-0.032, \mathrm{p}=0.9\right]\right)$. Due to the small number of CMhm and CMt co-infected cats, no statistical analysis of this haemoplasma status group was possible.

All 6 haemoplasma-specific primer pairs evaluated for conventional 16S rRNA gene PCR and sequencing amplified the predicted size PCR product. The primer pairs selected for amplifying and sequencing each haemoplasma species (Table 1 ) were chosen due to their absence of non-target haemoplasma species amplification and a lack of primer dimer formation.

Comparison of nucleotide identity within the $10 \mathrm{Mhf}, 10 \mathrm{CMhm}$ and 11 CMt sequences generated in the current study showed $>99.8 \%$, $>98.5 \%$ and $>98.8 \%$ identity, respectively, with each other. Alignment of the sequences generated in this study and those available on GenBank, for each of the three haemoplasma species, revealed 99.2\%$100 \%$ identity for Mhf, $98.4 \%-100 \%$ for CMhm and $97.8 \%-100 \%$ identify for CMt

The phylogenetic relationships of the sequences generated in this study and those available on GenBank are shown in Fig. 2. This analysis yielded the expected separation of Mhf, CMhm and CMt sequences into three distinct clades accompanied by high bootstrap values. The Mhf sequences all grouped into one single clade with other worldwide Mhf sequences from both domestic and wild cats. However, grouping of the CMhm sequences into three distinct subclades was seen; subclades one and two compromised eight of the ten CMhm sequences from this study and were most closely related to wild cat haemoplasma sequences from Africa, Brazil and Spain; and subclade three consisted of two sequences that shared a closer evolutionary relationship with sequences from domestic cats in Europe (UK and Switzerland). The CMt phylogenetic analysis also showed division into three subclades; five of the $11 \mathrm{CMt}$ sequences from this study grouped into subclades one and two, which were more closely related to sequences from domestic cats in Australia and Africa, whereas the CMt sequences in subclade three were more closely related to domestic and wild cat sequences from European countries (Switzerland, UK, France).

\section{Discussion}

Evidence for the presence of all three feline haemoplasma species in domestic cats in Brazil's capital and surrounding areas was found in this study. The overall haemoplasma prevalence was similar to those reported in the Brazilian states of RJ (Macieira et al., 2008), MA (Braga et al., 2012), SP (de Bortoli et al., 2012), MT (Miceli et al., 2013) and in studies from UK (Tasker et al., 2003a) and Italy (Gentilini et al., 2009), however studies conducted in stray cats from other Brazilian states (André et al., 2014; Santis et al., 2014; Santos et al., 2009), Portugal (Martínez-Díaz et al., 2013) and Italy (Spada et al., 2014) reported higher overall prevalences. The individual CMhm and CMt prevalences were similar to previous Brazilian studies (André et al., 2014; Braga et al., 2012; Macieira et al., 2008; Miceli et al., 2013; Santis et al., 2014; Santos et al., 2009), however the Mhf prevalence was higher than those previously reported in RS (Santos et al., 2009), MA (Braga et al., 2012) and MT (Miceli et al., 2013). As would be expected, the individual prevalence figures found in our study were lower than those in international studies where only cats attending veterinary practitioners (Jenkins et al., 2013; Lobetti and Lappin, 2012; Spada et al., 2014; Sykes et al., 2007) or cats with a clinical suspicion of haemoplasmosis (Jenkins et al., 2013; Lobetti and Lappin, 2012; Spada et al., 2014; Sykes et al., 2007) were sampled; but higher than those found in clinically normal cats used as blood donors (Hackett et al., 2006).

These differences in prevalence may reflect variations in the groups of cats studied and the risk factors for haemoplasma infection. The cat populations from previous Brazilian studies were diverse and included feral free-roaming cats (André et al., 2014; Santis et al., 2014), owned cats from neutering programmes (de Bortoli et al., 2012; Santis et al., 
Table 3

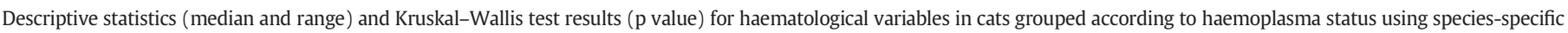
quantitative PCR results.

\begin{tabular}{|c|c|c|c|c|c|c|}
\hline Variable & $\begin{array}{l}\text { Negative cats } \\
(\mathrm{n}=372)\end{array}$ & $\begin{array}{l}\text { CMhm alone } \\
(\mathrm{n}=10)\end{array}$ & $\begin{array}{l}\text { Mhf and CMhm } \\
(\mathrm{n}=31)\end{array}$ & $\begin{array}{l}\text { CMhm and CMt } \\
(\mathrm{n}=2)^{\mathrm{a}}\end{array}$ & $\begin{array}{l}\text { Mhf and CMhm and CMt } \\
(\mathrm{n}=17)\end{array}$ & $\mathrm{p}$ value \\
\hline PCV (\%) & $31(4-53)$ & $31(21-38)$ & $29.5(8-44)$ & $30(27-34)$ & $27(12-34)$ & 0.11 \\
\hline $\mathrm{RBC}\left(\times 10^{6} / \mu \mathrm{L}\right)$ & $8(0.9-16)$ & $9(4.4-10.6)$ & $7.5(1.2-12.5)$ & $8.9(7-10.7)$ & $8.1(3-9.8)$ & 0.25 \\
\hline Haemoglobin concentration $(\mathrm{g} / \mathrm{dL})$ & $11.5(1.5-19.4)$ & $11.2(7.8-14.9)$ & $11.5(2.6-17.2)$ & $11(10.3-11.8)$ & $10.9(3.9-15.6)$ & 0.73 \\
\hline $\mathrm{MCV}(\mathrm{fl})$ & $38(16-110)$ & $37.4(30.5-47.4)$ & $38.4(29.4-66.1)$ & $34.8(31.5-38.2)$ & $37.9(27.6-66.9)$ & 0.5 \\
\hline $\mathrm{MCHC}(\%)$ & $36.7(12.6-71.6)$ & $36.8(30-51.3)$ & $36.2(28-55.4)$ & $36.4(34.7-38.1)$ & $38(28.8-51-8)$ & 0.74 \\
\hline
\end{tabular}

Values indicate median and range.

$\mathrm{PCV}=$ packed cell volume.

$\mathrm{RBCs}=$ red blood cells

$\mathrm{MCV}=$ mean corpuscular volume.

$\mathrm{MCHC}=$ mean corpuscular haemoglobin concentration

$\mathrm{CMhm}=$ "Candidatus Mycoplasma haemominutum".

Mhf = Mycoplasma haemofelis.

$\mathrm{CMt}=$ "Candidatus Mycoplasma turicensis".

a Group not included in the statistical evaluation due to the small number of cats.

2014), cats attending a feline only clinic and local veterinary hospitals (Macieira et al., 2008; Santos et al., 2009), owned cats screened for blood donation (Santos et al., 2009), feral cats housed in animal shelters (Miceli et al., 2013; Santos et al., 2009) and owned cats with outdoor access (Braga et al., 2012). Direct contact with stray or feral cats in an outdoor environment is believed to be a risk factor for haemoplasma infection (Willi et al., 2006a). Feral cats are probably more likely to be directly infected with haemoplasmas due to fighting, however the number of feral cats included in our study was low, representing $9.3 \%$ of the study population and status regarding outdoor access wasn't available for the household cats. In addition, it might be expected that more haemoplasma infection would be detected among cats that attend clinics and veterinary hospitals due to their ill-health. Also, regional differences such as climate and, therefore, the extent and timing of ectoparasite exposure may play a role in haemoplasma prevalence (Willi et al., 2006a). Direct comparison between studies is difficult when there are differences in factors such as inclusion criteria, local weather, indoor versus outdoor access as well as the PCR assays used for diagnosis. The current study, to the best of our knowledge, is the first haemoplasma prevalence study in cats from Brazil that has used qPCR for diagnosis.

Over $80 \%$ of haemoplasma positive cats ( 50 out 60 ) were co-infected with more than one haemoplasma species in the current study. Although many authors have reported the presence of cats with double or triple infection (André et al., 2014; de Bortoli et al., 2012; Santis et al., 2014), the proportion of co-infected cats in this study was significantly higher than previously reported in RS (16\%) (Santos et al., 2009), MS (45\%) (Santis et al., 2014), RJ (16.6\%) (Macieira et al., 2008), MA (20.8\%) (Braga et al., 2012), SP (33.3\%) (André et al., 2014; de Bortoli et al., 2012) and MT (6.6\%) (Miceli et al., 2013). The presence of many triple and dual co-infected cats in our study could be because the haemoplasma species share related risk factors and/or similar routes of transmission. In line with this is the fact that cats infected with one haemoplasma can also exhibit an increased susceptibility to infection with other haemoplasmas species (Willi et al., 2006a). Additionally, correlations between CMt and Mhf and between CMt and CMhm have been previously reported (Willi et al., 2006b).

Only one cat was positive by the generic haemoplasma PCR but negative by the haemoplasma species-specific qPCRs. This sample may have had a low haemoplasma copy number, below the limit of the qPCR assay sensitivity (Sykes et al., 2007) or it may have contained a novel haemoplasma species with mutations in the qPCR primer or probe binding sites. A false positive result in the generic haemoplasma PCR cannot be ruled out, although negative controls were appropriately negative throughout. Ideally this DNA sample would have been subjected to PCR amplification with an alternative generic haemoplasma qPCR assay (Tasker et al., 2010) and attempts made to sequence any amplicons, but sadly no remaining DNA was available from this cat.

Previous risk factor studies (Jenkins et al., 2013; Tasker et al., 2003a; Willi et al., 2006a) found that male cats are more likely to be infected with haemoplasmas than female cats, in line with the findings of our study. The increased prevalence in males may be because of a higher likelihood of male cats being infected with haemoplasmas due their behaviour patterns such as roaming, biting and fighting. Indeed, it is possible that haemoplasmas are directly transmitted, as suggested by the detection of CMhm and CMt DNA in the saliva of infected cats (Dean et al., 2008; Museux et al., 2009), although aggressive interaction is believed to be required, as direct transmission of haemoplasma infection was found to require exposure to haemoplasma infected blood rather than haemoplasma infected saliva (Museux et al., 2009). Also, other pathogens directly transmitted through fighting interactions, such as feline immunodeficiency virus (FIV), may induce immunosuppression that favours haemoplasma infection (Jenkins et al., 2013). Unfortunately evaluation of the concurrent retrovirus status of all of the cats in this study was not possible.

It has been stated that haemoplasma positive cats are more likely to be anaemic than negative cats (Lobetti and Tasker, 2004; Tasker et al., 2004, 2009; Willi et al., 2005), mainly during Mhf infection (Gentilini et al., 2009; Jenkins et al., 2013; Lobetti and Lappin, 2012; Lobetti and Tasker, 2004). However, our study as well as others (Barker et al., 2010; Bauer et al., 2008; Macieira et al., 2008; Martínez-Díaz et al., 2013; Spada et al., 2014; Wengi et al., 2008; Willi et al., 2006a) failed to demonstrate association between haemoplasma infection and anaemia. As hypothesised previously (Sykes, 2010; Willi et al., 2006a), changes in haematological parameters during haemoplasma infection vary according to infection stage (acute versus chronic), which haemoplasma species are present, varying pathogenicity, haemoplasma species strain variation and/or host factors such as age. The infection stage for the cats in our study was unknown as this is difficult to determine in naturally infected cats, and age was not recorded.

Some have suggested that anaemia tends to be present in coinfected cats as an additive effect of feline haemoplasma species on clinical disease (Willi et al., 2006b). However, the group of co-infected cats in our study didn't have significantly lower haematological parameters than those with single infections or no infection (Table 3), similar to previous findings (Willi et al., 2006a). Haematological changes in coinfected cats could also be influenced by the same factors (e.g. infection stage) as those proposed for single infections above.

As only naturally infected cats were sampled in the current study, and many cats were co-infected with more than one haemoplasma species, it was not possible to assess which haemoplasma species, if any, infected the cat first. It thus was not feasible to evaluate the effect 


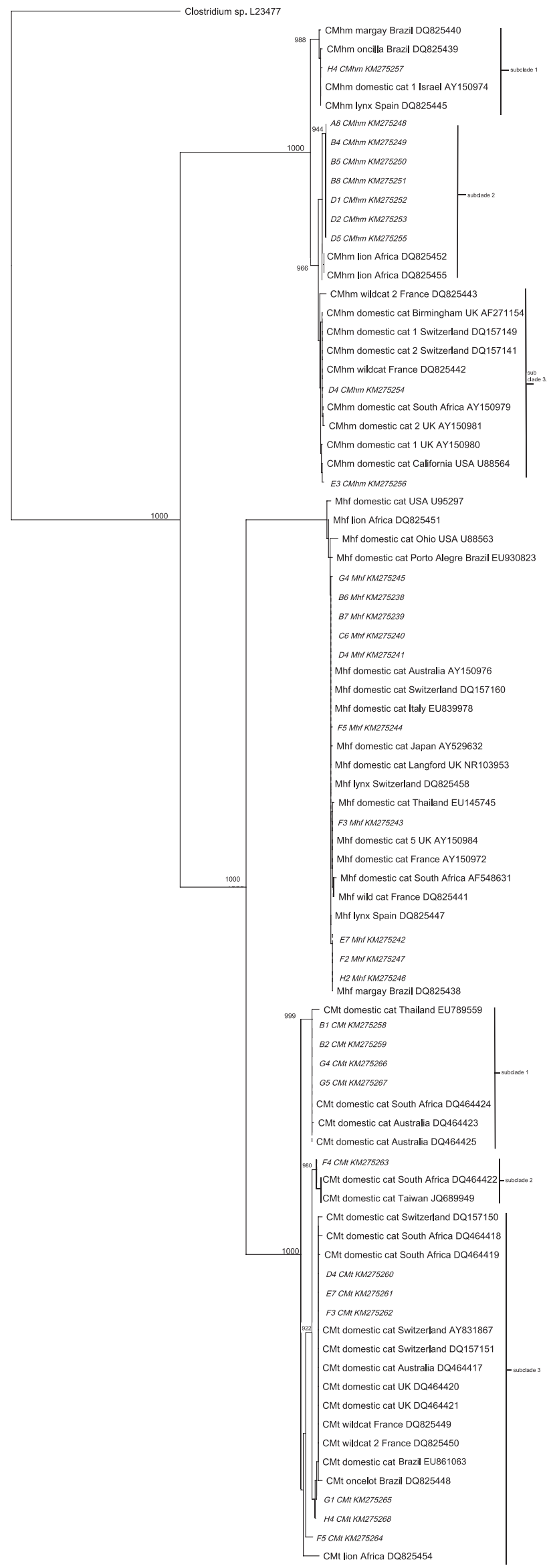

that one haemoplasma species had had on the presence of other species, and how the order of infection could have affected haematological parameters and relative copy numbers.

Cats with dual or triple haemoplasma co-infections were very common in our study, precluding the use of universal 16S rRNA gene primers for amplification and sequencing of the near-complete $16 \mathrm{~S}$ rRNA gene of the individual haemoplasma species in these cats. Therefore, the design of new species-specific 16S rRNA gene primers made possible the sequencing of individual haemoplasma species from 12 cats with triple and 10 cats with dual infections (Fig. 2). To the best of our knowledge this is the first report of the use of this approach to obtain individual haemoplasma species sequences from cats with dual and triple co-infections.

Phylogenetic 16S rRNA gene-based analysis showed our sequences to separate into three distinct groups, one for each of the three haemoplasma species (Fig. 2). The CMhm and CMt groups showed further subdivision into subclades as described in some (Tasker et al., 2003b; Willi et al., 2006b), but not all (Braga et al., 2012; Miceli et al., 2013; Santis et al., 2014), previous studies. Interestingly, the CMhm sequences that grouped into subclade two (Fig. 2) in the current study were closely related to African lions, which were also shown to have a high frequency of haemoplasma co-infections in a previous study (Willi et al., 2007). However not all of CMhm sequences from subclade two were derived from cats with multiple haemoplasma infections, as 2 of the 7 cats had single CMhm infections. Thus phylogenetic grouping is not strictly associated with haemoplasma co-infections. The subclade formation within the CMhm and CMt clades showed grouping of sequences from different regions worldwide and from different host types (i.e. wild versus domestic cats). As the phylogenetic divergence among strains may be reflected in phenotypic differences (Tasker et al., 2001), our findings suggest the existence of distinct strains, which may be related to varying pathogenicity, geographical distribution or host species. Unfortunately no specific definitions of exactly what constitutes a haemoplasma species strain exist.

Unlike the CMhm and CMt sequences, and as previously observed (Braga et al., 2012; Tasker et al., 2003b; Willi et al., 2007), the Mhf sequences in the current study did not reveal any subclade formation. The reasons for this difference in the 16S rRNA gene stability among haemoplasma species are not known.

Although phylogenetic information derived from a highly conserved gene, such as $16 \mathrm{~S}$ rRNA, is often used, additional phylogeny using non16S rRNA gene sequences, as has been undertaken in a few studies (Hicks et al., 2014; Peters et al., 2008a; Tasker et al., 2003b), would have been helpful to support our conclusions. However, the high number of co-infected cats made the amplification of other genes, such as RNase P RNA gene, very difficult since the design of speciesspecific primers is fraught with difficulty due to the short length of these genes. Further analysis of a larger number of genes and cases in the future, using alternative methods, would however be helpful in further refining the relationships established in our phylogenetic study.

\section{Conclusion}

This represents the first study to molecularly characterise the nearcomplete 16S rRNA gene sequences in haemoplasmas from domestic cats with a high prevalence of co-infections, using a technique employing

Fig. 2. Phylogenetic analysis of near complete $16 \mathrm{~S}$ rRNA gene sequences from Mhf, CMhm and CMt species in cats from Brasília and surrounding areas. The Neighbor-joining method was used to construct the phylogenetic tree with bootstrap values provided at the nodes (only values $\geq 700$ are shown). Evolutionary distances are to the scales shown. Clostridium spp. was used as an out-group. GenBank accession numbers are indicated in the figure. Mhf sequences (B6, B7, C6, D4, E7, F2, F3, F5, G4, H2), CMhm sequences (A8, B4, B5, B8 D1, D2, D4, D5, E3, H4) and CMt sequences (B1, B2, D4, E7, F3, F4, F5, G1, G4, G5, H4) were generated in the current study. Mhf = Mycoplasma haemofelis, $\mathrm{CMhm}=$ "Candidatus Mycoplasma haemominutum”, CMt = “Candidatus Mycoplasma turicensis". 
species-specific primers. Haematological variables were also evaluated. Future studies should investigate the significance of co-infections in wild and domestic hosts within the epidemiology of haemoplasma infections.

\section{Acknowledgements}

We would like to thank Coordenação de Aperfeiçoamento de Pessoal de Nivel Superior (CAPES) for Larissa Campos Aquino's personal research fellowship; the residents and interns from the Laboratory of Veterinary Clinical Pathology at University of Brasília for the great logistic support given to this study; and the School of Veterinary Sciences and the Molecular Diagnostic Unit, Langford Veterinary Services at University of Bristol for mentoring and laboratory support. We also acknowledge all owners who allowed their cats' samples to be included in this study. Chelsea Hicks was kindly supported by a BBSRC (BF/ F016662/1) doctoral training grant and Zoetis Animal Health.

\section{References}

André, M.R., Baccarim Denardi, N.C., Marques de Sousa, K.C., Gonçalves, L.R., Henrique P.C., Grosse Rossi Ontivero, C.R., Lima Gonzalez, I.H., Cabral Nery, C.V., Fernandes Chagas, C.R., Monticelli, C., Alexandre de Santis, A.C., Machado, R.Z., 2014 Arthropod-borne pathogens circulating in free-roaming domestic cats in a zoo environment in Brazil. Ticks Tick Borne Dis. 5 (5), 545-551.

Barker, E.N., Tasker, S., Day, M.J., Warman, S.M., Woolley, K., Birtles, R., Georges, K.C. Ezeokoli, C.D., Newaj-Fyzul, A., Campbell, M.D., Sparagano, O.A., Cleaveland, S., Helps, C.R., 2010. Development and use of real-time PCR to detect and quantify Mycoplasma haemocanis and "Candidatus Mycoplasma haematoparvum" in dogs. Vet. Microbiol. 140, 167-170.

Bauer, N., Balzer, H.J., Thüre, S., Moritz, A., 2008. Prevalence of feline haemotropic mycoplasmas in convenience samples of cats in Germany. J. Feline Med. Surg. 10, 252-258.

Biondo, A.W., Dos Santos, A.P., Guimaraes, A.M., Vieira, R.F., Vidotto, O., Macieira Dde, B. Almosny, N.R., Molento, M.B., Timenetsky, J., de Morais, H.A., Gonzalez, F.H. Messick, J.B., 2009a. A review of the occurrence of hemoplasmas (hemotrophic mycoplasmas) in Brazil. Rev. Bras. Parasitol. Vet. 18, 1-7.

Biondo, A.W., Dos Santos, A.P., Guimarães, A.M., Vieira, R.F., Vidotto, O., Macieira, D.e.B Almosny, N.R., Molento, M.B., Timenetsky, J., de Morais, H.A., González, F.H., Messick, J.B., 2009b. A review of the occurrence of hemoplasmas (hemotrophic mycoplasmas) in Brazil. Rev. Bras. Parasitol. Vet. 18, 1-7.

Birkenheuer, A.J., Levy, M.G., Breitschwerdt, E.B., 2003. Development and evaluation of a seminested PCR for detection and differentiation of Babesia gibsoni (Asian genotype) and B. canis DNA in canine blood samples. J. Clin. Microbiol. 41, 4172-4177.

Braga, M.S., André, M.R., Freschi, C.R., Teixeira, M.C., Machado, R.Z., 2012. Molecular detection of hemoplasma infection among cats from São Luís island, Maranhão, Brazil Braz. J. Microbiol. 43, 569-575

Criado-Fornelio, A., Martinez-Marcos, A., Buling-Saraña, A., Barba-Carretero, J.C., 2003. Presence of Mycoplasma haemofelis, Mycoplasma haemominutum and piroplasmids in cats from southern Europe: a molecular study. Vet. Microbiol. 93, 307-317.

de Bortoli, C.P., André, M.R., Seki, M.C., Pinto, A.A., Machado, S.e.T., Machado, R.Z., 2012. Detection of hemoplasma and Bartonella species and co-infection with retroviruse in cats subjected to a spaying/neutering program in Jaboticabal, SP, Brazil. Rev. Bras. Parasitol. Vet. 21, 219-223.

Dean, R.S., Helps, C.R., Gruffydd Jones, T.J., Tasker, S., 2008. Use of real-time PCR to detect Mycoplasma haemofelis and 'Candidatus Mycoplasma haemominutum' in the saliva and salivary glands of haemoplasma-infected cats. J. Feline Med. Surg. 10, 413-417.

dos Santos, A.P., dos Santos, R.P., Biondo, A.W., Dora, J.M., Goldani, L.Z., de Oliveira, S.T., de Sá Guimarães, A.M., Timenetsky, J., de Morais, H.A., González, F.H., Messick, J.B., 2008. Hemoplasma infection in HIV-positive patient, Brazil. Emerg. Infect. Dis. 14, 1922-1924

Gentilini, F., Novacco, M., Turba, M.E., Willi, B., Bacci, M.L., Hofmann-Lehmann, R., 2009. Use of combined conventional and real-time PCR to determine the epidemiology of feline haemoplasma infections in northern Italy. J. Feline Med. Surg. 11, 277-285.

Girotto, A., Zangirolamo, A.F., Bogado, A.L., Souza, A.S., da Silva, G.C., Garcia, J.L., Vilas Boas, L.A., Biondo, A.W., Vidotto, O., 2012. Molecular detection and occurrence of 'Candidatus Mycoplasma haemobos' in dairy cattle of Southern Brazil. Rev. Bras. Parasitol. Vet. 21, 342-344

Grazziotin, A.L., Santos, A.P., Guimaraes, A.M., Mohamed, A., Cubas, Z.S., de Oliveira, M.J. dos Santos, LC, de Moraes, W., Vieira, R.F. Donatti, L, de Barros Filho, IR., Biondo, A.W., Messick, J.B., 2011. Mycoplasma ovis in captive cervids: prevalence, molecular characterization and phylogeny. Vet. Microbiol. 152, 415-419.

Guimaraes, A.M., Javorouski, M.L., Bonat, M., Lacerda, O., Balbinotti, B., Queiroz, L.G., Timenetsky, J., Biondo, A.W., Messick, J.B., 2007. Molecular detection of “Candidatus Mycoplasma haemominutum" in a lion (Panthera leo) from a Brazilian zoological garden. Rev. Inst. Med. Trop. Sao Paulo 49, 195-196.

Hackett, T.B., Jensen, W.A., Lehman, T.L., Hohenhaus, A.E., Crawford, P.C., Giger, U., Lappin, M.R., 2006. Prevalence of DNA of Mycoplasma haemofelis, 'Candidatus Mycoplasma haemominutum', Anaplasma phagocytophilum, and species of Bartonella, Neorickettsia and Ehrlichia in cats used as blood donors in the United States. J. Am. Vet. Med. Assoc. 229, 700-705.
Hicks, C.A., Barker, E.N., Brady, C., Stokes, C.R., Helps, C.R., Tasker, S., 2014. Non-ribosomal phylogenetic exploration of Mollicute species: new insights into haemoplasma taxonomy. Infect. Genet. Evol. 23, 99-105.

Jenkins, K.S., Dittmer, K.E., Marshall, J.C., Tasker, S., 2013. Prevalence and risk factor analysis of feline haemoplasma infection in New Zealand domestic cats using a real-time PCR assay. J. Feline Med. Surg. 15, 1063-1069.

Lobetti, R., Lappin, M.R., 2012. Prevalence of Toxoplasma gondii, Bartonella species and haemoplasma infection in cats in South Africa. J. Feline Med. Surg. 14, 857-862.

Lobetti, R.G., Tasker, S., 2004. Diagnosis of feline haemoplasma infection using a real-time PCR assay. J. S. Afr. Vet. Assoc. 75, 94-99.

Macieira, D.B., de Menezes, R.e.C., Damico, C.B., Almosny, N.R., McLane, H.L., Daggy, J.K., Messick, J.B., 2008. Prevalence and risk factors for hemoplasmas in domestic cats naturally infected with feline immunodeficiency virus and/or feline leukemia virus in Rio de Janeiro-Brazil. J. Feline Med. Surg. 10, 120-129.

Martínez-Díaz, V.L., Silvestre-Ferreira, A.C., Vilhena, H., Pastor, J., Francino, O., Altet, L., 2013. Prevalence and co-infection of haemotropic mycoplasmas in Portuguese cats by real-time polymerase chain reaction. J. Feline Med. Surg. 15, 879-885.

Messick, J.B., 2004. Hemotropic mycoplasmas (hemoplasmas): a review and new insights into pathogenic potential. Vet. Clin. Pathol. 33, 2-13.

Miceli, N.G., Gavioli, F.A., Gonçalves, L.R., André, M.R., Sousa, V.R., Sousa, K.C., Machado, R.Z., 2013. Molecular detection of feline arthropod-borne pathogens in cats in Cuiabá, state of Mato Grosso, central-western region of Brazil. Rev. Bras. Parasitol. Vet. 22, 385-390.

Museux, K., Boretti, F.S., Willi, B., Riond, B., Hoelzle, K., Hoelzle, L.E., Wittenbrink, M.M., Tasker, S., Wengi, N., Reusch, C.E., Lutz, H., Hofmann-Lehmann, R., 2009. In vivo transmission studies of 'Candidatus Mycoplasma turicensis' in the domestic cat. Vet. Res. 40, 45.

Peters, I.R., Helps, C.R., McAuliffe, L., Neimark, H., Lappin, M.R., Gruffydd-Jones, T.J., Day, M.J., Hoelzle, L.E., Willi, B., Meli, M., Hofmann-Lehmann, R., Tasker, S., 2008a. RNase P RNA gene (rnpB) phylogeny of hemoplasmas and other Mycoplasma species. J. Clin. Microbiol. 46, 1873-1877.

Peters, I.R., Helps, C.R., Willi, B., Hofmann-Lehmann, R., Tasker, S., 2008b. The prevalence of three species of feline haemoplasmas in samples submitted to a diagnostics service as determined by three novel real-time duplex PCR assays. Vet. Microbiol. 126, 142-150.

Santis, A.C., Herrera, H.M., Sousa, K.C., Goncalves, L.R., Denardi, N.C., Domingos, I.H., Campos, J.B., Machado, R.Z., Andre, M.R., 2014. Molecular detection of hemotrophic mycoplasmas among domiciled and free-roaming cats in Campo Grande, state of Mato Grosso do Sul, Brazil. Rev. Bras. Parasitol. Vet. 23, 231-236.

Santos, A.P., Messick, J.B., Biondo, A.W., Oliveira, S.T., Pedralli, V., Lasta, C.S., Lacerda, L.A., Esteves, V.S., Hofmann-Lehmann, R., Willi, B., Gonzalez, F.H., 2009. Design, optimization, and application of a conventional PCR assay with an internal control for detection of 'Candidatus Mycoplasma turicensis' 16S rDNA in domestic cats from Brazil. Vet. Clin. Pathol. 38, 443-452.

Spada, E., Proverbio, D., Galluzzo, P., Della Pepa, A., Bagnagatti De Giorgi, G., Perego, R., Ferro, E., 2014. Prevalence of haemoplasma infections in stray cats in northern Italy. ISRN Microbiol. 2014, 298352

Steer, J.A., Tasker, S., Barker, E.N., Jensen, J., Mitchell, J., Stocki, T., Chalker, V.J., Hamon, M., 2011. A novel hemotropic Mycoplasma (hemoplasma) in a patient with hemolytic anemia and pyrexia. Clin. Infect. Dis. 53, e147-e151.

Sykes, J.E., 2010. Feline hemotropic mycoplasmas. Vet. Clin. North Am. Small Anim. Pract. $40,1157-1170$

Sykes, J.E., Drazenovich, N.L., Ball, L.M., Leutenegger, C.M., 2007. Use of conventional and real-time polymerase chain reaction to determine the epidemiology of hemoplasma infections in anemic and nonanemic cats. J. Vet. Intern. Med. 21, 685-693.

Sykes, J.E., Lindsay, L.L., Maggi, R.G., Breitschwerdt, E.B., 2010. Human coinfection with Bartonella henselae and two hemotropic mycoplasma variants resembling Mycoplasma ovis. J. Clin. Microbiol. 48, 3782-3785.

Tasker, S., Helps, C.R., Belford, C.J., Birtles, R.J., Day, M.J., Sparkes, A.H., Gruffydd-Jones, T.J., Harbour, D.A., 2001. 16S rDNA comparison demonstrates near identity between a United Kingdom Haemobartonella felis strain and the American California strain. Vet. Microbiol. 81, 73-78.

Tasker, S., Binns, S.H., Day, M.J., Gruffydd-Jones, T.J., Harbour, D.A., Helps, C.R., Jensen, W.A., Olver, C.S., Lappin, M.R., 2003a. Use of a PCR assay to assess the prevalence and risk factors for Mycoplasma haemofelis and 'Candidatus Mycoplasma haemominutum' in cats in the United Kingdom. Vet. Rec. 152, 193-198.

Tasker, S., Helps, C.R., Day, M.J., Harbour, D.A., Shaw, S.E., Harrus, S., Baneth, G., Lobetti, R.G., Malik, R., Beaufils, J.P., Belford, C.R., Gruffydd-Jones, T.J., 2003b. Phylogenetic analysis of hemoplasma species: an international study. J. Clin. Microbiol. 41, 3877-3880.

Tasker, S., Braddock, J.A., Baral, R., Helps, C.R., Day, M.J., Gruffydd-Jones, T.J., Malik, R., 2004. Diagnosis of feline haemoplasma infection in Australian cats using a real-time PCR assay. J. Feline Med. Surg. 6, 345-354.

Tasker, S., Peters, I.R., Papasouliotis, K., Cue, S.M., Willi, B., Hofmann-Lehmann, R., Gruffydd-Jones, T.J., Knowles, T.G., Day, M.J., Helps, C.R., 2009. Description of outcomes of experimental infection with feline haemoplasmas: copy numbers, haematology, Coombs' testing and blood glucose concentrations. Vet. Microbiol. 139, 323-332.

Tasker, S., Peters, I.R., Mumford, A.D., Day, M.J., Gruffydd-Jones, T.J., Day, S., Pretorius, A.M., Birtles, R.J., Helps, C.R., Neimark, H., 2010. Investigation of human haemotropic Mycoplasma infections using a novel generic haemoplasma qPCR assay on blood samples and blood smears. J. Med. Microbiol. 59, 1285-1292.

Thrusfield, M.V., 1986. Veterinary Epidemiology. viii. Butterworths, London; Boston (280 pp.).

Vieira, R.F., Molento, M.B., dos Santos, L.C., Moraes, W., Cubas, Z.S., Santos, A.P., Guimaraes, A.M., Mohamed, A., Barros Filho, I.R., Biondo, A.W., Messick, J.B., 2009. Detection of a novel hemoplasma based on 16S rRNA gene DNA in captive and free-ranging capybaras (Hydrochaeris hydrochaeris). Vet. Microbiol. 139, 410-413. 
Wengi, N., Willi, B., Boretti, F.S., Cattori, V., Riond, B., Meli, M.L., Reusch, C.E., Lutz, H. Hofmann-Lehmann, R., 2008. Real-time PCR-based prevalence study, infection follow-up and molecular characterization of canine hemotropic mycoplasmas. Vet. Microbiol. 126, 132-141.

Willi, B., Boretti, F.S., Cattori, V., Tasker, S., Meli, M.L., Reusch, C., Lutz, H., HofmannLehmann, R., 2005. Identification, molecular characterization, and experimental transmission of a new hemoplasma isolate from a cat with hemolytic anemia in Switzerland. J. Clin. Microbiol. 43, 2581-2585.

Willi, B., Boretti, F.S., Baumgartner, C., Tasker, S., Wenger, B., Cattori, V., Meli, M.L., Reusch, C.E., Lutz, H., Hofmann-Lehmann, R., 2006a. Prevalence, risk factor analysis, and follow-up of infections caused by three feline hemoplasma species in cats in Switzerland. J. Clin. Microbiol. 44, 961-969.

Willi, B., Tasker, S., Boretti, F.S., Doherr, M.G., Cattori, V., Meli, M.L., Lobetti, R.G., Malik, R. Reusch, C.E., Lutz, H., Hofmann-Lehmann, R., 2006b. Phylogenetic analysis of "Candidatus Mycoplasma turicensis" isolates from pet cats in the United Kingdom, Australia, and South Africa, with analysis of risk factors for infection. J. Clin. Microbiol. 44, 4430-4435. Willi, B., Filoni, C., Catão-Dias, J.L., Cattori, V., Meli, M.L., Vargas, A., Martínez, F., Roelke M.E., Ryser-Degiorgis, M.P., Leutenegger, C.M., Lutz, H., Hofmann-Lehmann, R., 2007. Worldwide occurrence of feline hemoplasma infections in wild felid species. J. Clin. Microbiol. 45, 1159-1166. 
ANEXO B - Comprovante de submissão do artigo 2 em revista científica

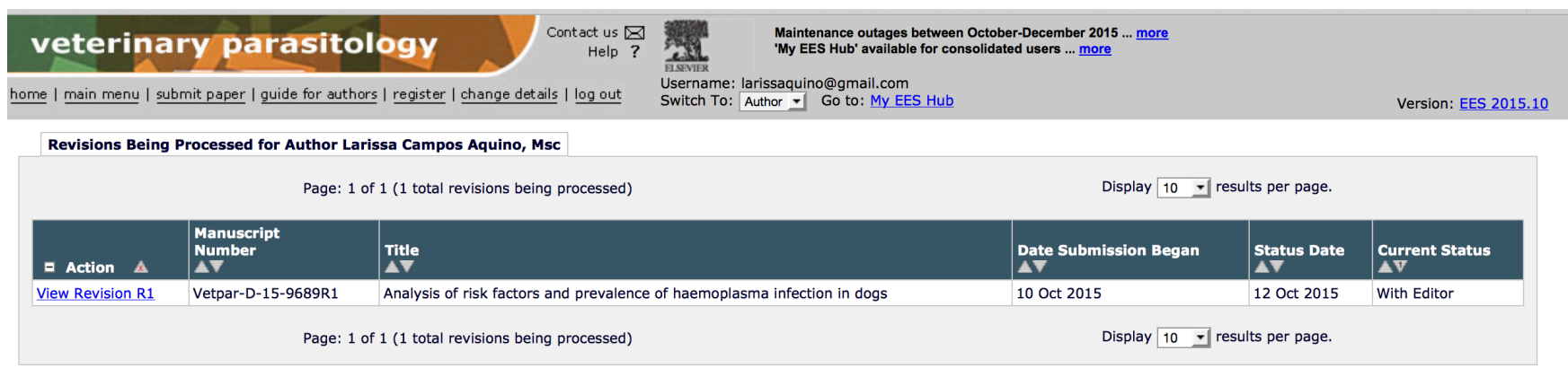

$\ll$ Author Main Menu 